NATALIA JULIANA NARDELLI GONÇALVES

Geração de célula-tronco pluripotente canina: fatores envolvidos no estabelecimento da reprogramação por indução gênica

São Paulo

2015 


\section{NATALIA JULIANA NARDELLI GONÇALVES}

Geração de célula-tronco pluripotente canina: fatores envolvidos no estabelecimento da reprogramação por indução gênica

Tese apresentada ao Programa de PósGraduação em Anatomia dos Animais Domésticos e Silvestres da Faculdade de Medicina Veterinária e Zootecnia da Universidade de São Paulo para obtenção do título de Doutor em Ciências

\section{Departamento:}

Cirurgia

Área de Concentração:

Anatomia dos Animais Domésticos e Silvestres

Orientador:

Prof. Dr. Carlos Eduardo Ambrósio 
Autorizo a reprodução parcial ou total desta obra, para fins acadêmicos, desde que citada a fonte.

\section{DADOS INTERNACIONAIS DE CATALOGAÇÃO-NA-PUBLICAÇÃO}

(Biblioteca Virginie Buff D’Ápice da Faculdade de Medicina Veterinária e Zootecnia da Universidade de São Paulo)

\begin{tabular}{|c|c|}
\hline \multirow[t]{6}{*}{ FMVZ } & $\begin{array}{l}\text { Gonçalves, Natalia Juliana Nardelli } \\
\text { Geração de célula-tronco pluripotente canina: fatores envolvidos no estabelecimento da } \\
\text { reprogramação por indução gênica / Natalia Juliana Nardelli Gonçalves. -- } 2015 \text {. } \\
130 \text { f. : il. }\end{array}$ \\
\hline & $\begin{array}{l}\text { Tese (Doutorado) - Universidade de São Paulo. Faculdade de Medicina Veterinária e } \\
\text { Zootecnia. Departamento de Cirurgia, São Paulo, } 2015 \text {. }\end{array}$ \\
\hline & Programa de Pós-Graduação: Anatomia dos Animais Domésticos e Silvestres. \\
\hline & Área de concentração: Anatomia dos Animais Domésticos e Silvestres. \\
\hline & Orientador: Prof. Dr. Carlos Eduardo Ambrósio. \\
\hline & 1. iPSC. 2. Reprogramação. 3. Pluripotência. 4. Células-tronco. I. Título. \\
\hline
\end{tabular}




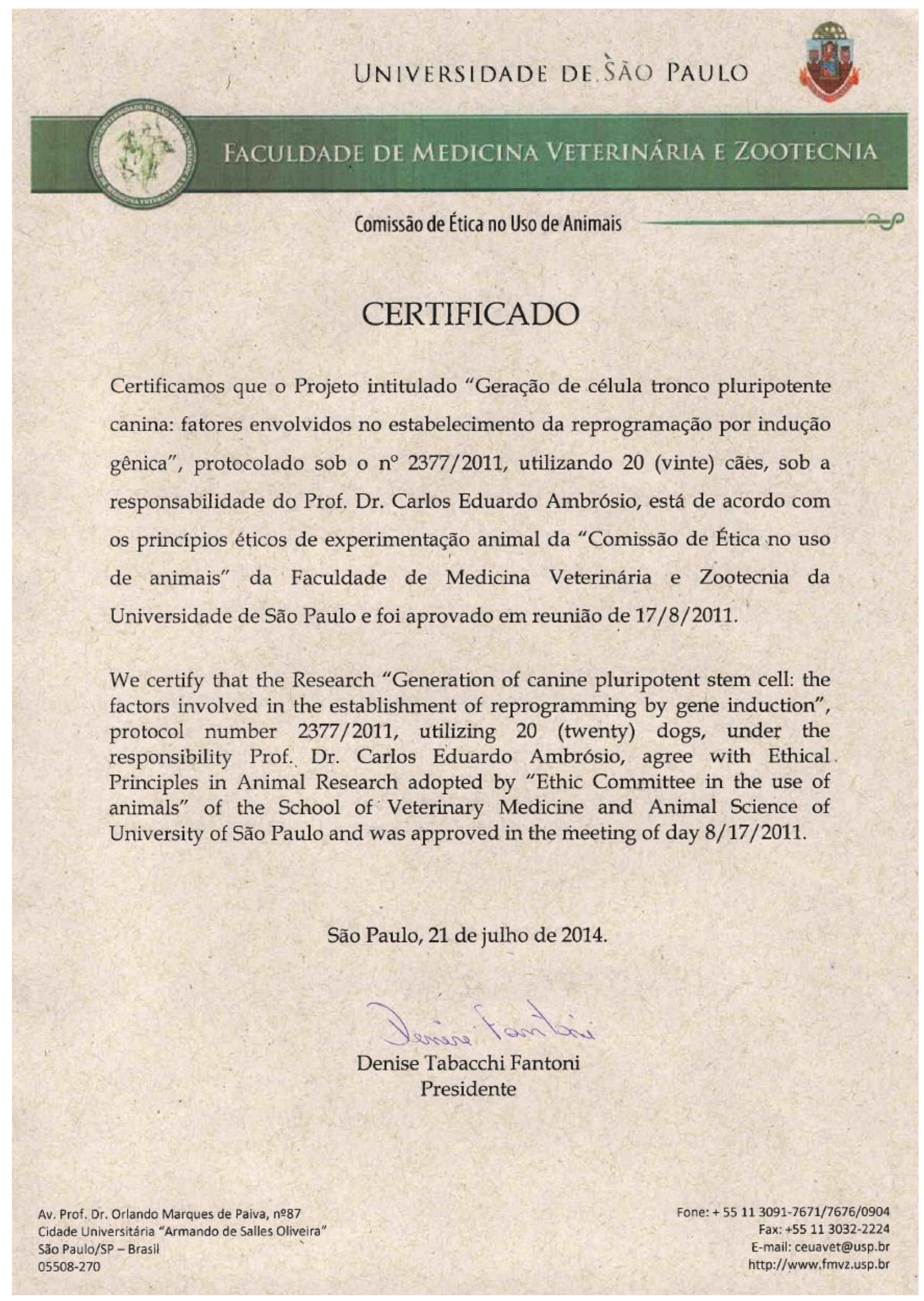




\section{FOLHA DE AVALIAÇÃO}

Nome: GONÇALVES, Natalia Juliana Nardelli

Título: Geração de célula-tronco pluripotente canina: fatores envolvidos no estabelecimento da reprogramação por indução gênica

Tese apresentada ao Programa de PósGraduação em Anatomia dos Animais Domésticos e Silvestres da Faculdade de Medicina Veterinária e Zootecnia da Universidade de São Paulo para obtenção do título de Doutor em Ciências

Data:

\section{Banca Examinadora}

Prof. Dr.

Instituição: Julgamento:

Prof. Dr.

Instituição: Julgamento:

Prof. Dr.

Instituição: Julgamento:

Prof. Dr.

Instituição: Julgamento:

Prof. Dr. Instituição: Julgamento: 


\section{DEDICATÓRIA}

Dedico este trabalho a meu pai, Edison Tadeu Gonçalves (in memoriam), que é o amor que move a minha vida, o sorriso que me incentiva, a mão que me segura em todos os momentos, os olhos que brilharam a cada conquista minha. Seus ensinamentos e sua sabedoria me trouxeram aqui e ainda me conduzirão em voos mais altos.

"Metade de mim

Agora é assim

De um lado a poesia, o verbo, a saudade

Do outro a luta, a força e a coragem pra chegar no fim

E ofim é belo incerto... Depende de como você vê O novo, o credo, a fé que você deposita em você e só"

o Teatro Mágico 


\section{AGRADECIMENTOS}

Galopamos pela vida como artistas de circo, equilibrados em dois cavalos que correm lado a lado a toda velocidade - com um pé sobre o cavalo chamado 'destino', e o outro sobre o cavalo chamado 'livre arbitrio'.

O primeiro e maior agradecimento, é de fato a aqueles dos bastidores, mas que me deram a felicidade e força necessárias para todas as batalhas. Agradeço primeiro, a Deus, e a todos os seres de luz que me guiam e protegem. Minha mãe e grande amiga Ana, sua força e coragem de sempre seguir em frente me incentivam a todo momento, sua admiração por quem eu sou é meu combustível, você me ajuda a ser uma pessoa melhor todos os dias. Meu irmão Diego e meu pai Edison, vocês foram e sempre serão a força motriz de tudo, o fôlego, o afago na minha alma. Não poderia deixar de citar aqui, Júlio e Amora, meus filhos de quatro patas, vocês me ensinam todos os dias com a pureza do seu amor, sou mais feliz depois que vocês chegaram. Meu amor eterno a vocês, depois de tantas dores superadas. Essa tese é mais do que a concretização de um sonho, é um grito de vitória, uma vitória que eu dedico a vocês.

Ela sempre vai querer o melhor.

O teu, o do mundo e, principalmente, o dela

Nada mais justo do que lembrar que nenhum trabalho se constrói sozinho e eu sou muito grata por ter contado com pessoas tão especiais e que junto comigo abraçaram essa causa e deram seu melhor, fazendo parte da concretização desta tese. Ao longo dos anos foram muitas conversas científicas e um grande intercâmbio de conhecimento, e me sinto muito orgulhosa do resultado. A todos que me auxiliaram nessa jornada, meu mais sincero obrigada, e minhas desculpas a aqueles que por um esquecimento não tiveram seus nomes citados aqui.

Prof. Carlos Eduardo Ambrósio, meu orientador e amigo, fez mais do que me orientar, me ensinou a caminhar sozinha e sempre depositou em mim grande confiança, me deixando livre para tomar os caminhos que julguei adequados ao longo deste trabalho. Obrigada por todo conhecimento, por todo suporte, por todo incentivo, por todas as conversas científicas e não científicas. Sua parceria nos momentos mais difíceis estão registrados em meu coração para sempre, saiba que me sinto honrada em ser parte do seu time. 
Fabiana Bressan, minha amiga Martini, este trabalho também é seu. Nenhuma palavra aqui seria capaz de expressar minha gratidão por ter me ensinado tanto, minha gratidão por ter "segurado as pontas" quando eu não pude estar presente. Minha parceira de trabalho e companheira dos bons e maus momentos. Me sinto muito privilegiada por ter você como parte dessa tese e principalmente da minha vida.

Não poderia me esquecer dos professores que muito me ajudaram nessa jornada. Profa. Daniele dos Santos Martins pela amizade em todos os momentos e ajuda, tão essencial, com os camundongos. Prof. Flávio Vieira Meirelles, Prof. Heidge e Prof. Felipe, muito obrigada pelos ensinamentos e ajuda sempre que necessário.

Aos colegas de laboratório obrigada por todas as conversas, risadas, descontração e ajuda científica. Vocês tornaram estes anos cheios de boas recordações: Aline, Ana, Bruna, Luciana, Cury, Matheus, Maitê, Gabi, Vanessa, Kelly, Mariana, Mariane, Camila, Yonara, Arina, Pedro Luiz, Thaís Lessa, e minha companheira de kit, Lenita, enfim, todos do GDTI, LMMD e GMA meu muito obrigada por todos os momentos compartilhados. Muito obrigada ao Atanásio e Alessandra pela ajuda com a dissecção dos camundongos, a minha querida Naira Godoy, por toda ajuda histológica e com as imagens, Lídia Hildebrand com as avaliações histopatológicas e Ju Casals sempre tão empenhada na coleta de material.

A todo o grupo do Hemocentro, por toda parceria e suporte e em especial a Dra. Danielle Magalhães pelo auxílio com os experimentos de microscopia confocal.

Ao professor Dr. Jorge Piedrahita e toda sua equipe, em especial a ajuda do Dr. Sehwon Koh e Dr. Breen, foi um prazer trabalhar com vocês na Universidade da Carolina do Norte, bem como encontrar amigos como Renan Sper, que ficarão para toda a vida. Obrigada por toda ajuda, conhecimento e momentos de descontração, esta foi a fase mais intensa e cheia de aprendizado e sou feliz por ter sido com vocês.

A aqueles que são mais que colegas de laboratório, e fazem parte hoje da minha jornada pessoal, vocês tornaram meus dias mais leves, a rotina mais branda. Laís, minha amiga, 
obrigada por todas as conversas, pela amizade sincera, você, Pedrinho, Paulinho e Martini que me acolheram sempre, se tornaram minha família em Pirassununga.

Existem coisas na vida que nunca serão medidas pela quantidade, mas pela qualidade e, talvez, a mais importante de todas elas seja a Amizade. Cris, Lícia, Fernando, Deborah, Simoni, Renata, Arthur, teria sido muito mais difícil sem vocês. A minha querida Tuca, por seu suporte nessa jornada de aprendizado da vida, gratidão sempre. A todos meus amigos de longa data e aos recém chegados, que tiveram sua importância em algum momento, que seguraram minha mão, que foram parceiros nos momentos difíceis, àqueles que me surpreenderam e se fizeram presentes e verdadeiros, meu muito obrigada, porque nada é mais essencial nessa vida do que ter amigos, sou grata a todos vocês, e fato é que ninguém é feliz sozinho.

À Faculdade de Zootecnia e Engenharia de Alimentos (FZEA/USP), à Faculdade de Medicina Veterinária e Zootecnia e ao programa de Pós-Graduação em Anatomia dos animais domésticos e silvestres (FMVZ/USP) por todo suporte.

A Fundação de Amparo à Pesquisa do Estado de São Paulo (FAPESP) por todo suporte financeiro (2011/22915-5 e 201209631-0).

Ao final da vida, é esse o tipo de história que a gente vai querer contar. Histórias que nos façam protagonistas, não coadjuvantes; histórias que nos tornem heróis de nós mesmos, simplesmente por termos agido com verdade, honestidade, dignidade, respeito e amor pelo que fomos, pelo que nos tornamos, por todos os sonhos que, por mais malucos que parecessem, a gente não hesitou em realizar. 


\section{RESUMO}

GONÇALVES, N. N. Geração de célula-tronco pluripotente canina: fatores envolvidos no estabelecimento da reprogramação por indução gênica. [Generation of canine pluripotent stem cells: factors involved in the establishment of reprogramming by gene induction]. 2015. $130 \mathrm{f}$. Tese (Doutorado em Ciências) - Faculdade de Medicina Veterinária e Zootecnia, Universidade de São Paulo, São Paulo, 2015.

A produção de células-tronco induzidas (iPSC) a partir de fibroblasto fetal canino abre caminhos para a obtenção de células pluripotentes e o estudo de sua aplicabilidade para terapias alternativas na medicina veterinária. Neste contexto, este trabalho investigou metodologias adequadas avaliando a eficiência destas, para a produção de células-tronco pluripotentes no modelo canino in vitro (CTE-like), uma vez que a produção de células-tronco embrionárias verdadeiras, cultivadas a partir da MCI de blastocistos, ainda não foi completamente caracterizada em animais domésticos. Os experimentos visaram o aumento do conhecimento de fatores envolvidos no processo de reprogramação em cães, bem como a produção de tais linhagens e sua completa caracterização. No primeiro experimento, foi comparada a infecção retroviral, já padronizada por diversos grupos, com a reprogramação epissomal, inédita para a espécie, na tentativa de induzir células à pluripotência sem a integração viral, e ainda, estratégias para o aumento da eficiência de reprogramação, onde o plasmídeo epissomal foi somado a fatores de transcrição. A reprogramação epissomal gerou colônias quando acrescida do fator $c-M Y C$, que provavelmente, aumentou a proliferação destas células produzindo colônias iPS com morfologia típica e positivas para o teste da fosfatase alcalina. Tais resultados, ainda preliminares pra conclusões, são essenciais para o processo de obtenção de linhagens sem a integração viral, aumentando a aplicabilidade na terapia celular. No segundo experimento objetivou-se avaliar os fatores OCT4 e SOX2 associados a proteínas repórteres. Os fibroblastos que receberam estes fatores, foram analisados por citometria de fluxo, permitindo a avaliação da influência de cada fator no processo de reprogramação, além de permitir a separação (sorting) das células que integraram o gene, aumentando a eficiência de reprogramação e o conhecimento biológico dos mecanismos de integração rastreados por uma proteína repórter. A análise por microscopia de fluorescência revelou que a distribuição de proteínas repórteres foi semelhante entre as duas diferentes construções proteicas e que não se restringe a uma região da célula em particular. OCT4 e SOX2 mostraram uma elevada expressão exógena de cada gene alvo, bem como células dupla positivas. No entanto, nenhuma interação foi observada pelo menos 6 dias após a transdução. O último capítulo experimental descreveu o 
mecanismo de reprogramação por integração lentiviral para indução da pluripotência em fibroblastos fetais de cão. As linhagens obtidas e completamente caracterizadas neste estudo foram independentes de LIF ou qualquer outra suplementação com inibidores, resistentes ao repique enzimático (Tryple Express), sendo apenas bFGF dependentes. Foram obtidas 66 linhagens clonais, das quais $10(7 \mathrm{~h}+\mathrm{mOSKM}$ e $3 \mathrm{hOSKM})$ se mantiveram por 15 ou mais passagens e foram utilizadas para todos os testes de caracterização in vitro, com eficiência máxima de reprogramação de $0,001 \%$. Todas as colônias foram positivas para o teste da fosfatase alcalina, bem como formaram corpos embrióides e se diferenciaram de forma espontânea, além de expressarem altos níveis dos fatores endógenos OCT4 e SOX2. In vivo, as colônias foram capazes de desenvolver tumor 120 dias após a inoculação (confirmado por análise histopatológica) comprovando sua origem predominantemente mesodérmica. A integridade cromossomal das linhagens foi avaliada por hidridização FISH, que não evidenciou qualquer tipo de anomalia. A completa caracterização de tais linhagens, bem como os experimentos não integrativos e com fatores associados a proteínas repórteres, aumentam o conhecimento da tecnologia de reprogramação, estabelecendo novas estratégias para indução da pluripotência de forma mais eficaz e segura para seu uso em testes clínicos e terapia celular.

Palavras-chave: iPSC. Reprogramação. Pluripotência. Células-tronco. 


\begin{abstract}
GONÇALVES, N. N. Generation of canine pluripotent stem cells: factors involved in the establishment of reprogramming by gene induction. [Geração de célula-tronco pluripotente canina: fatores envolvidos no estabelecimento da reprogramação por indução gênica]. 2015. 130 f. Tese (Doutorado em Ciências) - Faculdade de Medicina Veterinária e Zootecnia, Universidade de São Paulo, São Paulo, 2015.
\end{abstract}

The production of induced pluripotent stem cells (iPSC) from canine fetal fibroblast opens new ways for obtaining pluripotent cells and study its applicability for alternative therapies in veterinary medicine. In this context, this study investigated appropriate methods for producing pluripotent stem cells using a in vitro canine model (ESC-like), so far the production of true embryonic stem cells from ICM cultured blastocysts has not been fully characterized in domestic animals. The experiments aimed at increasing knowledge of the factors involved in reprogramming process in dogs, as well as the production of such strains and complete characterization. In the first experiment, a retroviral infection was compared to episomal reprogramming (never done for this specie) in an attempt to induce cells to pluripotency state without viral integration, also to observe the development of cells receiving separately the episomal plasmid plus transcription factors. The generation of colonies was possible only in the episomal plus $c-M Y C$ factor group, leading to increased cell proliferation producing iPS colonies with typical morphology and positive for the alkaline phosphatase detection. These results, so far as preliminary conclusions, are essential to obtaining strains without viral integration, increasing its applicability for clinical cell therapy. In the second experiment, we aimed to evaluate the OCT4 and SOX2 factors associated with fluorescent reporter proteins. These were analyzed by flow cytometry allowing the performance evaluation of each factor on the reprogramming process the fluorescence activated separation of cells containing the integrated gene, increasing the enriching the efficiency of reprogramming. Fluorescence microscopy analysis showed that the distribution of reporter protein was similar between the two different protein structures and not restricted to a particular cell region. OCT4 and SOX2 showed a high exogenous expression of each target gene, and double positive cells. However, no colony formation was observed at least 6 days after transduction. The last experimental chapter aimed to described the reprogramming mechanism of lentiviral integration to induce pluripotency in dog fetal fibroblasts. The lines obtained were fully characterized in this study, showing independency of LIF or any other 
supplemental inhibitors, resistance to enzymatic process (Tryple Express) and bFGF dependency only. A total of 66 clonal strains were obtained (hOSKM and h+mOSKM) while $10(7 \mathrm{~h}+\mathrm{m}$ and $3 \mathrm{~h})$ were maintained for 15 or more passages and used for in vitro characterization tests, with maximum efficiency of reprogramming $0.001 \%$. All colonies were positive for the alkaline phosphatase detection, embryoid bodies formation, spontaneously differentiated and expressed high levels of endogenous OCT4 and SOX2. In vivo, the colonies were able to developed tumors 120 days after inoculation (confirmed via histopathology analysis), with predominantly mesodermal tissues. Chromosomal evaluations were made by FISH hybridization showing no chromosomal abnormality in iPSCs canine lines. The fully characterization of such lines as well as non-integrated experiments and factors associated via reporter proteins increases the knowledge of the iPSCs technology, establishing new strategies for more efficient and safe induction of pluripotency for potential use in cell therapy and clinical trials.

Key words iPSC. Reprogrammation. Pluripotency. Stem cell. 


\section{LISTA DE FIGURAS}

Figura 1 - Esquema dos métodos de reprogramação

Figura 2 - Expressão dinâmica de SOX2, OCT4 e NANOG durante o desenvolvimento murino

Figura 3 - $\quad$ Mapa do vetor oriP/EBNA 1

Figura 4 - Gel de agarose mostrando os fragmentos do plasmídeo após digestão enzimática

Figura 5- Fibroblastos caninos após a inserção do vetor epissomal por nucleofecção

Figura 6 - Células PLAT (A) com pMXs-mRFP1 usado para produção viral após 72 horas de transfecção 45

Figura 7 - Diagrama mostrando delineamento experimental 1 46

Figura 8- Fibroblastos em processo de reprogramação com vetor murino retroviral

Figura 9 - Fibroblastos caninos 15 dias pós reprogramação com vetor epissomal apenas, e com tratamentos dos fatores

Figura 10 - Colônias formadas a partir da combinação epissomal $+c-M Y C$

Figura 11- Colônias geradas a partir da combinação epissomal $+c-M Y C$, mostrando forte atividade de fosfatase alcalina

Figura 12 - Mapa dos vetores lentivirais OCT4-vexGFP e SOX2-mCitrine 54

Figura 13 - Mapa dos vetores auxiliares necessários para a produção lentiviral. 55

Figura 14 - Células 293FT fotografadas após 48h de transfecção, mostrando a produção viral 58

Figura 15 - Análise fluxo-citométrica de populações combinadas e separadas OCT4 e $S O X 2$, separadas por sorting

Figura 16- Análise fluxo-citométrica da população única de SOX2-mCitrine separadas por sorting 
Figura 17 - Microscopia confocal para fibroblastos caninos fetais expressando as proteínas repórteres fluorescentes

Figura 18 - Gráfico representando a expressão de hSOX2 e hOCT4, e a combinação dos fatores

Figura 19 - Embrião canino com aproximadamente 15 dias de idade gestacional, utilizado para o cultivo de fibroblastos

Figura 20 - Coleta de embriões murinos com 13,5 dias de idade gestacional....... 66

Figura 21 - Esquema representando construção do vetor policistrônico STEMCCA 67

Figura 22 - Plano experimental das células transduzidas - experimento 3. 69

Figura 23 - Esquema temporal do processo de reprogramação 69

Figura 24 - Fibroblastos caninos em processo de reprogramação com o vetor policistrônico humano, murino e a combinação de ambos .75

Figura 25 - Fibroblastos caninos em processo de reprogramação com o vetor policistrônico humano, murino e a combinação de ambos em D11 .75

Figura 26 - Diferenças morfológicas observadas no cultivo de iPSC canina em diferentes substratos

Figura 27 - Imagem sob estereomicroscópio mostrando o procedimento para repique manual

Figura 28 - Linhagens clonais expressando fosfatase alcalina 78

Figura 29 - Morfologia das colônias após repique enzimático adaptado com Tryple Express 79

Figura 30 - Formação de corpos embrióides cultivados em agarose, fotografados após 48 horas de cultivo. 80

Figura 31 - Diferenciação in vitro após 5 dias de cultivo em gelatina 81

Figura 32 - Gráfico representando a expressão de SOX2 nas linhagens IPS canina, comparadas a fibroblastos fetais não reprogramados, em unidades arbitrárias 82 
Figura 33 - Gráfico representando a expressão de OCT4 nas linhagens IPS canina, comparadas a fibroblastos fetais não reprogramados, em unidades arbitrárias

Figura 34 - Detecção da proteína OCT4, SOX2 e NANOG em linhagens clonais positivas, sob microscopia óptica e de fluorescência.

Figura 35 - Dados de contagem cromossomal de iPS canina com coloração DAPI e avaliação por hibridização in situ (FISH) 84

Figura 36 - Injeção subcutânea de linhagem clonal 4 h+m ciPS em Balb/c nude..... 85

Figura 37 - Avaliação macroscópica e microscópica dos órgãos para o Nude com formação tumoral. 86

Figura 38 - Avaliação macroscópica e microscópica dos órgãos para o Nude com formação tumoral 86

Figura 39 - Avaliação macroscópica e microscópica dos órgãos para o Nude sem formação tumoral

Figura 40 - Avaliação macroscópica e microscópica dos órgãos para o Nude sem formação tumoral 87

Figura 41 - Avaliação microscópica da massa teratogênica localizada em região cervical 88 


\section{LISTA DE QUADROS}

Quadro 1 - Semelhanças e diferenças entre CTE-like de cão, gato, suíno e equino comparadas as CTE de camundongo ............................................................. 32

Quadro 2 - Sequências dos primers usados para qPCR, de acordo com Bressan, 2013........57

Quadro 3 - Sequências dos primers utilizados para análise da pluripotência, de

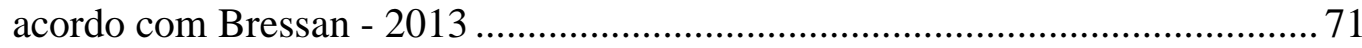




\section{LISTA DE TABELAS}

Tabela 1 - Delineamento dos 6 protocolos de transdução, com uso ou não de suplementação, combinando ou não os vetores humano e murino, reprogramando fibroblastos fetais caninos em duas concentrações iniciais. De todos os protocolos foram obtidas 66 linhagens clonais, das quais 18 (dos protocolos 4,5 e $6 \mathrm{~h}+\mathrm{m}$ e h) se mantiveram por no máximo 10 passagens e 10 se mantiveram por 15 ou mais passagens, sendo 7 h+mOSKM e 3 hOSKM em eficiência máxima de reprogramação de $0,001 \%$ 


\section{SUMÁRIO}

1 INTRODUÇÃ

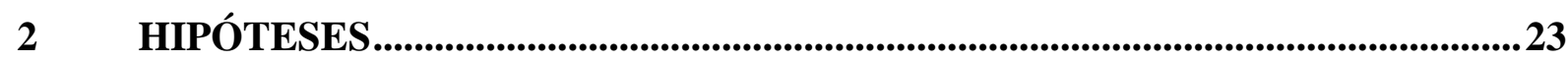

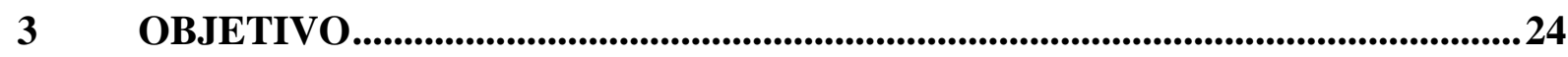

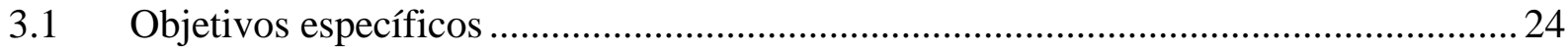

4 JUSTIFICATIVA ....................................................................................................25

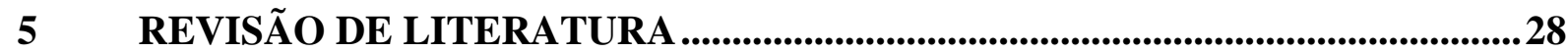

5.1 Células-Tronco: conceito e classificação.................................................................... 28

5.2 Células-tronco embrionárias e a medicina regenerativa em animais domésticos.......... 30

5.3 Células-tronco embrionárias e o modelo canino............................................................ 31

5.4 Pluripotência geneticamente induzida (Induced Pluripotent Stem Cell -IPSC) ............ 32

5.5 A corrida pelo aumento da eficiência no processo de reprogramação e a importância

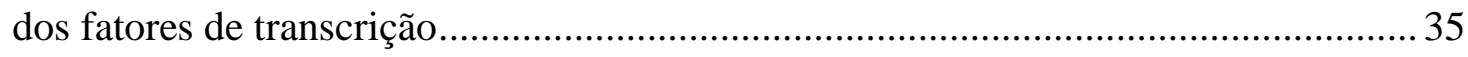

5.6 A reprogramação induzida e os fatores cromossomais e epigenéticos ............................36

6 AVALIAÇÃO DO PROCESSO DE REPROGRAMAÇÃO INDUZIDA A PARTIR DE VETORES EPISSOMAIS OU RETROVIRAIS ..................................41

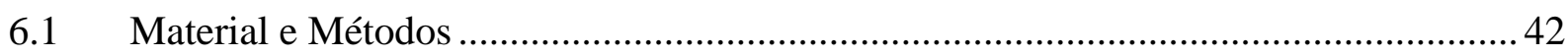

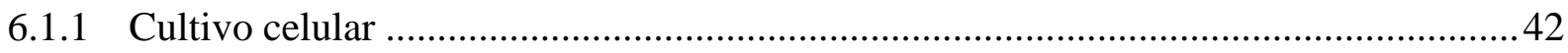

6.1.2 Monocamada de cultivo (MEFS) ........................................................................ 42

6.1.3 Produção Epissomal........................................................................................... 43

6.1.4 Escolha dos plasmídeos e enzimas de restrição …………………………………….... 43

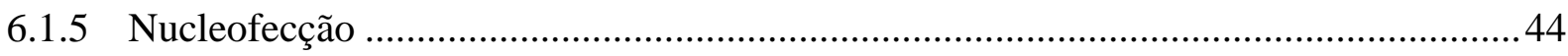

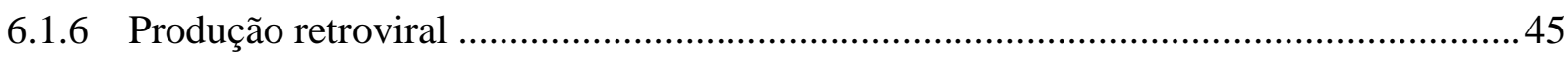

6.1.7 Geração de células de pluripotência induzida por sistema retroviral ............................45

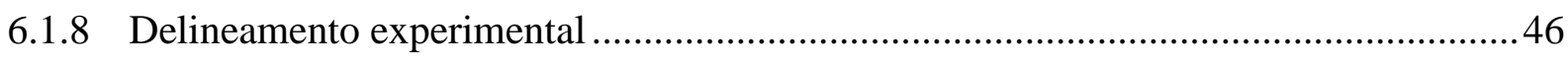

6.1.9 Fosfatase alcalina - caracterização in vitro ……………………………………….....4 47

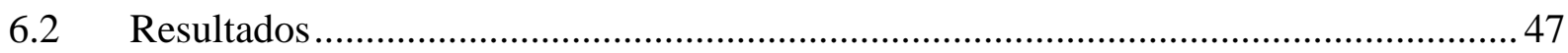

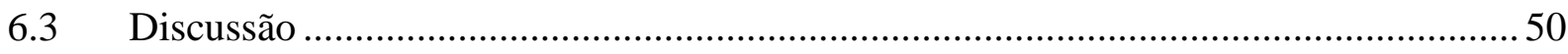

7 ANÁLISE DA EXPRESSÃO DE FATORES EXÓGENOS RELACIONADOS À PLURIPOTÊNCIA NO MODELO CANINO ............................................................53

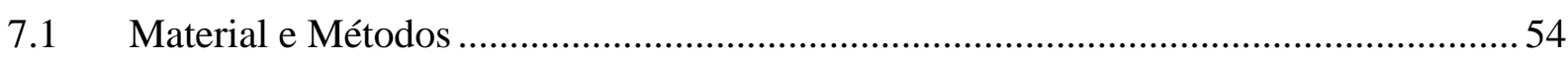

7.1.1 Derivação de linhagem de fibroblasto fetal canino …………………………………....54 


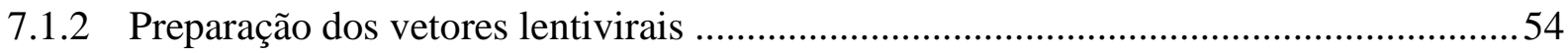

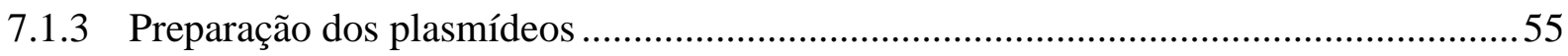

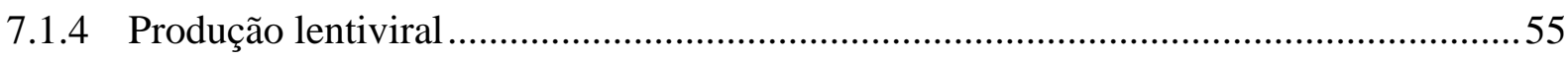

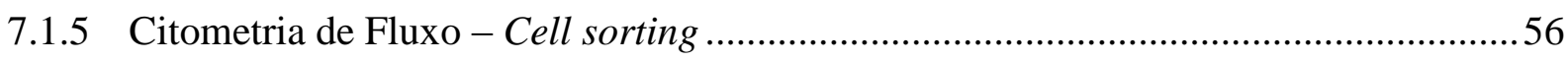

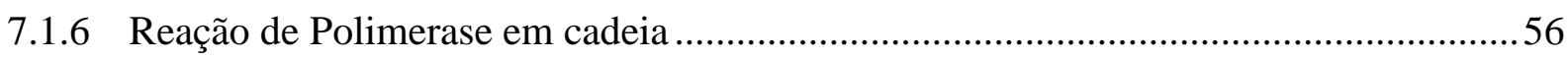

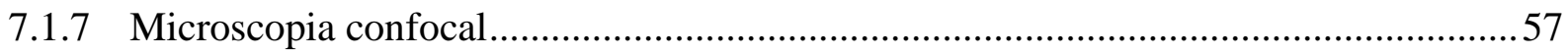

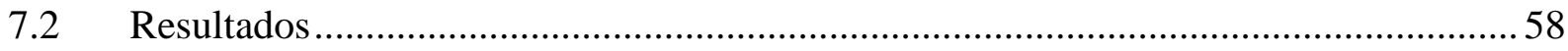

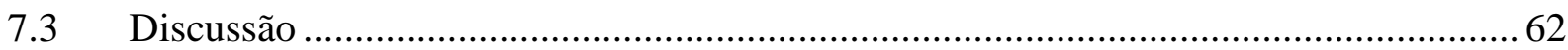

8 PRODUÇÃO E CARACTERIZAÇÃO DAS CÉLULAS PLURIPOTENTES INDUZIDAS NO MODELO CANINO.............................................................67

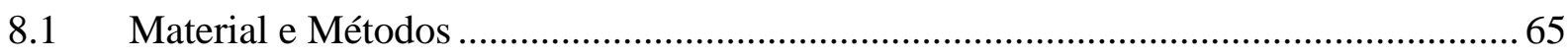

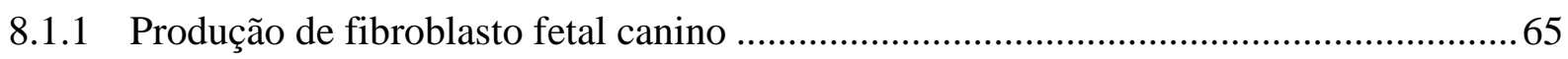

8.1.2 Produção de fibroblastos embrionários murinos para monocamada de cultivo ...........65

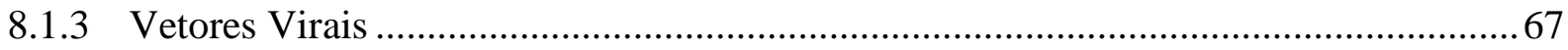

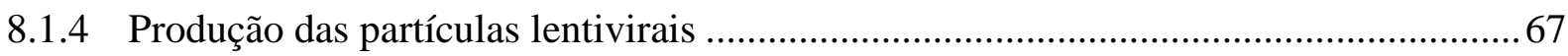

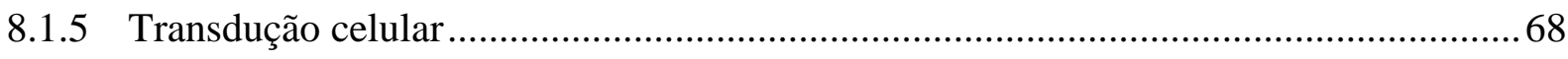

8.1.6 Detecção da expressão enzimática de fosfatase alcalina ............................................69

8.1.7 Formação de corpos embrióides e diferenciação in vitro ........................................... 70

8.1.8 Análise da expressão gênica de fatores relacionados à pluripotência .......................... 70

8.1.9 Detecção da proteína $O C T 4$, SOX2 e $N A N O G$ por imunofluorescência ....................... 71

8.1.10 Caracterização in vivo - formação de teratoma em camundongos imunosuprimidos

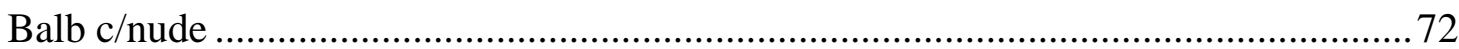

8.1.11 Separação de Metafase cromossomal e FISH......................................................... 72

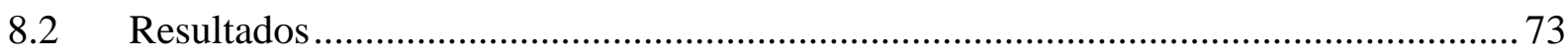

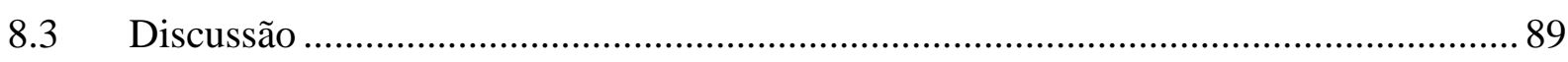

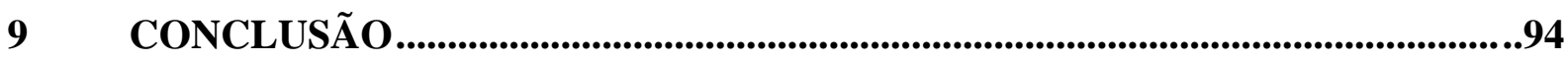

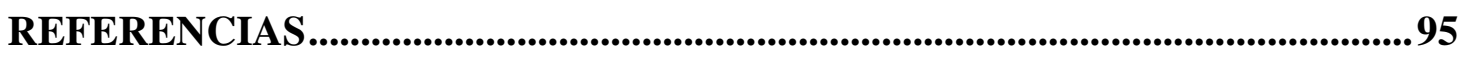

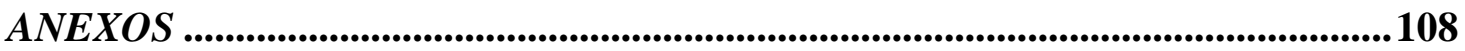




\section{INTRODUÇÃO}

A definição a respeito de células-tronco embrionárias (CTE) tem sido alterada ao longo dos anos, especialmente após a caracterização em humanas (THOMSON et al., 1998), onde propõe-se que tais células são verdadeiras quando se auto renovam extensivamente in vitro, mantém um cariótipo estável e normal, se diferenciam em tecidos provenientes dos três folhetos embrionários, expressam OCT4 e um painel de outros marcadores pluripotentes, e apresentam atividade de telomerase (HOFFMAN; CARPENTER, 2005). Infelizmente, algumas das características das CTEs que comprovam a sua pluripotência são as mesmas capazes de levar a uma diferenciação descontrolada, resultando muitas vezes em formações tumorais (WAKITANI et al., 2003; ARNHOLD et al., 2004), deixando sua aplicabilidade controversa e cercada por muitos desafios.

As importantes conquistas alcançadas com células-tronco embrionárias foram recentemente celebradas com o prêmio Nobel. Em 1962 Gurdon evidenciou pela primeira vez a capacidade de células diferenciadas retornarem ao estado de pluripotência, e então diversos cientistas derivaram estas células e delinearam a função dos genes relacionados a tal condição pluripotente (EVANS; KAUFMAN, 1981; DOETSCHMAN et al., 1987; THOMAS; CAPECCHI, 1987). No entanto, estes aspectos das células-tronco tem sido arduamente pesquisado e o público continua aguardando a próxima grande conquista: que elas sejam capazes de prover uma fonte ilimitada de material para medicina regenerativa. Aparentemente é difícil dizer quando isso ocorrerá, porém as pesquisas ainda são ambiciosas ao redor deste assunto e destas células tão promissoras, apesar de tão difíceis de serem caracterizadas. A persistente falta de métodos padronizados para a derivação, caracterização e manutenção de tais células, em especial para os animais domésticos, continua estimulando a busca por caminhos alternativos (BREVINI et al., 2008).

Diversos pesquisadores estão envolvidos principalmente no sentido de esclarecer e tornar real sua aplicabilidade na terapia celular. Com a evolução das técnicas de fertilização, maturação e transplante de embriões de diversas espécies, o estudo das células-tronco embrionárias tem se tornado uma metodologia palpável (DENNING; PRIDDLE, 2003; JEWGENOW; PARIS, 2006; MIGLINO et al., 2006; HOSKEN et al., 2007; NOWAKIMIALEK et al., 2011; BLOMBERG; TELUGU, 2012). Muitos trabalhos relatam com sucesso o isolamento de CTE derivadas de blastocisto de camundongos (MARTIN, 1981), humanos (AMIT; ELDOR, 2002), e primatas (THOMSON et al., 1995). Nos últimos anos, muitos esforços foram feitos neste sentido, porém escassos trabalhos referentes a carnívoros 
(especialmente os canídeos) são relatados, alegando-se dificuldades de isolamento nestes animais (TRAVIS et al., 2009; URANIO et al., 2011), algumas revisões descrevem tal dificuldade além de retratarem as perspectivas para os animais domésticos neste aspecto (GONÇALVES et al., 2014; KOH; PIEDRAHITA, 2014).

Dentre estes caminhos, células somáticas podem adquirir propriedades de CTE através da reprogramação nuclear. Os maiores enfoques incluem a transferência nuclear (TNCS), fusão celular e a introdução de fatores de transcrição específicos, reprogramando células somáticas ao estado de pluripotência. A reprogramação, como enfoque mais recente, foi reportado por Yamanaka et al. (2006), que juntamente com Gurdon, receberam o Nobel de Medicina em 2012, demonstrando que a expressão combinada dos fatores de transcrição OCT4, SOX2, KLF4 e c-MYC eram capazes de reprogramar células somáticas para a condição de CTE-like, nomeadas como células de pluripotência induzida (iPSCs). Desde sua descoberta, esta metodologia tem atraído muitos pesquisadores ao redor do mundo por sua relativa simplicidade e grande potencial na medicina regenerativa (LIANG; ZHANG, 2013).

A introdução destes genes de pluripotência exógenos induzem a expressão de genes endógenos da rede autorregulatória transcricional de pluripotência e o silenciamento total dos fatores exógenos estabelece o limiar entre células iPS totalmente ou parcialmente reprogramadas, sendo que o quadro ideal para as totalmente reprogramadas é o silenciamento exógeno e a manutenção da pluripotência passa a ser função do circuito endógeno (HOTTA; ELLIS, 2008; JAENICH; YOUNG, 2008).

Os esforços dos trabalhos mais recentes começam a se voltar para a correção de doenças, antes sem nenhuma perspectiva de cura, como a correção de mutações gênicas. Recentemente, Li et al. (2015) demonstraram a correção precisa da distrofia muscular de Duchenne em células iPSC humanas com o uso das tecnologias de edição gênica TALEN e CRISPR-cas9.

Neste momento da ciência, 30 anos após o primeiro isolamento de CTE em camundongos, ainda não existe um relato de CTE completamente caracterizada em animais domésticos. Os recentes avanços na tecnologia iPS provê a oportunidade de compreender a rede regulatória da pluripotência e elucidar as diferenças entre espécies (KOH el al., 2014). 


\section{HIPÓTESES}

1. A indução da pluripotência na espécie canina, bem como sua manutenção, é possível in vitro, a partir de fibroblastos fetais, usando fatores gênicos exógenos que induzam essa reprogramação.

2. É possível a formação de colônias iPS caninas sem a suplementação usualmente requerida (LIF e/ou inibidores)

3. Anomalias cromossomais podem ocorrer como consequência do processo de reprogramação induzida. 


\section{OBJETIVO}

Compreender os fatores envolvidos na integração de genes repórteres e na reprogramação por vetor epissomal, sem integração viral, delineando os fatores envolvidos no estabelecimento da indução a pluripotência. Além de obter linhagens estáveis de iPS canina geradas a partir de fibroblastos fetais, por infecção lentiviral e caracterizar tais linhagens in vivo e in vitro, bem como avaliar possíveis alterações cromossomais resultantes de tal reprogramação.

\subsection{Objetivos específicos}

$\checkmark$ Avaliar a integração dos genes repórteres associados a OCT4 e SOX2 e a expressão de tais fatores exógenos relacionados à pluripotência no modelo canino.

$\checkmark$ Avaliar se a reprogramação por vetor epissomal em células caninas é possível e eficaz.

$\checkmark$ Estabelecer uma linhagem geneticamente induzida de células-tronco de cães (ciPSC).

$\checkmark$ Caracterizar in vitro tais linhagens.

$\checkmark$ Comprovar a capacidade de diferenciação destas células nos folhetos embrionários in vivo, com a formação tumoral, comprovando sua pluripotência.

$\checkmark$ Desenvolvimento da tecnologia de indução à pluripotência no modelo canino, de forma otimizada, aumentando a eficácia e confiabilidade de testes clínicos.

$\checkmark$ Avaliar a presença ou não de anomalias cromossomais decorrentes do processo de reprogramação. 


\section{JUSTIFICATIVA}

Estudos com modelos animais têm mostrado que transplantes de células-tronco embrionárias ou pluripotentes podem ter sucesso para tratamento e cura de diversas doenças, muitas delas extremamente complexas. Porém o estudo de diferentes linhagens se faz necessário, com vistas à aquisição de culturas com baixa incidência carcinogênica. A medicina regenerativa amparada pelo desenvolvimento de biotecnologias emerge com futuro promissor, sendo uma das opções terapêuticas mais almejada. Nos últimos anos, tem ocorrido um significativo aumento de pesquisas nesta área e muito progresso já foi feito, o que justifica o aprofundamento do conhecimento e o desenvolvimento de competências em biotecnologia para dar sequência a estas pesquisas.

Neste contexto, este trabalho propõe a investigação dos fatores envolvidos com a indução da pluripotência, bem como uma metodologia adequada e eficiente para obtenção de células-tronco no modelo canino. Com o estabelecimento de culturas in vitro que se desenvolvam com padrões de expressão gênica e epigenéticos semelhantes às células derivadas do modelo animal. Desenvolvendo desta forma, uma biotecnologia otimizada para a espécie em questão, contribuindo com a medicina regenerativa, através da derivação e cultivo corretos das células-tronco embrionárias reprogramadas. 
A revisão de literatura desta tese foi baseada no artigo de revisão publicado em 2014 com o Dr. Jorge Piedrahita, da Universidade da Carolina do Norte, em parceria UGPN (The University Global Partnership Network/USP processo 13.1.4148.1.5)

Gonçalves, N. N.; Ambrosio, C. E.; Piedrahita, J. A. Stem Cells and Regenerative Medicine in Domestic and Companion Animals: A Multispecies Perspective. Reproduction in Domestic Animals, v. 49, p. 2-10, 2014. (Anexo 1) 


\section{REVISÃO DE LITERATURA}

\subsection{Células-Tronco: conceito e classificação}

Em geral, uma célula tronco se define como uma célula que tem a capacidade de dividir-se (auto replicar-se) por períodos indefinidos durante toda a vida de um indivíduo e que, em condições apropriadas e sinais corretos de microambiente, podem dar origem (diferenciação) a diferentes linhagens com características e funções especializadas. Em geral, o tipo celular mais amplo são as totipotentes, capazes de gerar um organismo completo, incluindo as membranas extra embrionárias, até as células-tronco unipotentes como um progenitor muscular, que pode se diferenciar em apenas um tipo celular (MITALIPOV; WOLF, 2009; MALAVER-ORTEGA et al., 2012; SIMARA et al., 2013).

Em relação aos mecanismos da diferenciação, diversos autores concluem que as células pluripotentes expressam um conjunto único de fatores responsáveis pelo estado de indiferenciação. Os fatores de transcrição OCT4 e $N A N O G$, foram os primeiros a serem identificados como essenciais. Uma rede interligada de genes regulatórios é responsável pelo desenvolvimento ou manutenção da pluripotência em embriões, porém, os componentes desta trama ainda não são totalmente conhecidos (NICHOLS et al., 1998; MITSUI et al., 2003; CAI et al., 2015).

As células-tronco também estão presentes em tecidos maduros, sendo denominadas de células-tronco adultas, e também contribuem para o desenvolvimento pós-natal por substituir células já diferenciadas que são perdidas devido à injúria, apoptose programada ou turnover fisiológico (DE BARI et al., 2001). De acordo com o tipo de tecido que originam, existem quatro tipos de células-tronco: totipotentes, pluripotentes, multipotentes e unipotentes. $\mathrm{O}$ termo totipotente refere-se ao potencial que estas células têm de gerar um embrião completo (tecido embrionário e extra embrionário). Pluripotente é utilizado para descrever as célulastronco que podem dar origem a progenitores que formam qualquer um dos folhetos germinativos embrionários: mesoderme, endoderme e ectoderme (MARTIN, 1981; EVANS et al., 2003; BREVINI et al., 2008; YU et al., 2008; KUIJK et al., 2010). É importante destacar que para que uma célula possa considerar-se como pluripotente tem que cumprir as seguintes condições: em primeiro lugar uma única célula deve ser capaz de diferenciar-se a progenitores especializados procedentes de qualquer folheto embrionário; em segundo lugar, demonstrar a 
funcionalidade in vitro e in vivo das células em que se diferenciou (THOMPSON; BJORKLUND; 2015).

Células tronco multipotentes estão presentes em vários órgãos adultos, podendo se diferenciar em diversos tipos celulares, geralmente provenientes do mesmo folheto embrionário, como as células tronco mesenquimais e as células tronco hematopoiéticas (NARDI; MEIRELLES, 2006). A última categoria corresponde às células-tronco unipotentes, que só podem gerar células filhas que se diferenciam em uma única linhagem celular (KUIJK et al., 2010). A maioria das células-tronco de um tecido específico que não tenha sofrido qualquer tipo de agressão ou dano são de tipo unipotente e são responsáveis pela fase fisiológica de auto-renovação tissular, onde a quantidade de células perdidas é igual ao número de novas células. No entanto, se o tecido é alterado em sua estrutura básica, através de um fenômeno lesivo, diversos tipos celulares são recrutados para sua reparação, então as células do tipo pluripotentes são ativadas para reparar o dano (WEISSMAN et al., 2001).

O estabelecimento de células-tronco embrionárias por explante da massa celular interna derivado de blastocistos de camundongo foi reportado pela primeira vez 34 anos atrás (EVANS; KAUFMAN, 1981; MARTIN, 1981), seguido por primatas não-humanos (THOMSON et al., 1995) e humanos (THOMSON et al., 1998; REUBINOFF et al., 2000). Desde o primeiro isolamento em humanos, ficou determinado que estas células in vitro se diferenciavam espontaneamente em estruturas multicelulares conhecidas como corpos embrionários, que contém elementos dos três folhetos germinativos, a partir das quais se podem formar vários tipos de células como cardiomiócitos, neurônios e progenitores hematopoiéticos (VERFAILLIE et al., 2002).

As células-tronco embrionárias (derivadas do blastocisto) e as germinais (derivadas após implantação do blastocisto) são similares em muitos aspectos; ambas são capazes de replicar-se e dividir-se em cultivos por longos períodos de tempo sem mostrar alterações cromossômicas. Entretanto, elas diferem do tecido de onde provém e em seu comportamento in vivo; as células-tronco embrionárias são capazes de gerar teratomas enquanto que as germinais não (SHAMBLOTT et al., 1998; ODORICO et al., 2001; SAITO et al., 2002; VERFAILLIE et al., 2002; SEMB, 2005).

Uma das vantagens do uso das células-tronco embrionárias é sua habilidade de se proliferar indefinidamente e sua capacidade de gerar uma grande variedade de grupos celulares, o que permite que quando em condições ideais, possam ser manipuladas in vitro com a finalidade de produzir precursores de uma linhagem específica para o tratamento de enfermidades como diabetes e Parkinson que apresentam tecidos claramente comprometidos 
(WEISSMAN, 2000). Em contrapartida, por tratar-se de células altamente indiferenciadas, podem induzir a formação de certas neoplasias como teratomas e as implicações éticas por seu uso são um ponto muito importante a considerar (DOSS et al., 2004).

\subsection{Células-tronco embrionárias e a medicina regenerativa em animais domésticos}

Um grande número de pesquisadores tem escrito revisões e desenvolvido pesquisas com o tópico células-tronco embrionárias em animais domésticos (TRAVIS et al., 2009; WILCOX et al., 2009; BLOMBERG; TELUGU, 2012; GALDOLFI et al., 2012; MALAVER-ORTEGA et al., 2012; NOWAK-IMIALEK et al., 2011). Clarificando o caminho para obtenção de células embrionárias e otimizando as pesquisas, diversas linhagens tem sido diferenciadas e proliferadas, mas poucas satisfazem todos os requisitos para uma célula tronco embrionária verdadeira (KOH; PIEDRAHITA 2014).

Os primeiros esforços para derivar tais células de animais que não fossem de laboratório foi registrada por Evans et al. (1990) que descreveu células pluripotentes de embriões suínos e bovinos. Piedrahita et al. (1990a) estabeleceram diversas linhagens suínas cultivadas em associação com monocamadas de cultivo, tais linhagens foram caracterizadas como capazes de se diferenciar espontaneamente nos três folhetos embrionários. Os resultados publicados não eram otimistas, sugerindo que tal crescimento e estabelecimento em suínos e ovinos era muito mais complexo do que em camundongos. Dando continuidade a tal pesquisa, reportou o efeito de diferentes monocamadas de cultivo no estabelecimento de tais linhagens, concluindo que nenhum dos testes foi capaz de otimizar o processo de isolamento de células-tronco embrionárias destas espécies (PIEDRAHITA et al., 1990b). Muitos trabalhos foram publicados desde então (revisado por BREVINI et al., 2008; MALAVERORTEGA et al., 2012) e 25 anos após as pesquisas iniciais ainda não existe nenhum relato conclusivo de isolamento de células-tronco do blastocisto de suínos.

Em bovinos, uma recente revisão descreve os esforços dos últimos 25 anos em isolar e manter CTE-like e mantê-las por apenas algumas passagens, expressando marcadores de pluripotencia como SSEA-1, OCT4, SSEA-4 e NANOG e hábeis a formar teratomas quando injetadas em camundongos imunossuprimidos, porém, mostrando anomalias cromossomais e assim como em suínos, ainda não há uma descrição de linhagens de CTE verdadeiras para essa espécie (revisado por MALAVER-ORTEGA et al., 2012).

Em gatos, o primeiro trabalho data de 2008 onde Yu et al. reportaram CTE-like obtidas da massa celular interna (MCI) de embriões cultivados em monocamada de 
fibroblastos embrionários da mesma espécie. Estas células mostraram típica morfologia, foram positivas para fosfatase alcalina e para marcadores de pluripotência; formaram corpos embrióides e in vitro se diferenciaram em células do miocárdio. No entanto, nenhuma dessas linhagens se manteve indiferenciada quando em cultivo por longo período. No segundo trabalho, publicado dois anos depois (GOMEZ et al., 2010) as células isoladas também não eram capazes de formar teratoma ou quimera. Desta forma, também não foi caracterizada até o momento uma linhagem CTE verdadeira em gatos.

Os equinos, uma espécie de extrema importância para estudos clínicos, teve seu primeiro relato científico em 2002 com isolamento de CTE-like (SAITO et al., 2002) isoladas de blastocistos congelados e com cariótipo normal. Em 2006, Li et al. assim como Guest e Allen (2007) estabeleceram CTE-like a partir da MCI que se mantiveram por 50 passagens, mais uma vez, sem a capacidade de formar teratomas ou quimeras.

\subsection{Células-tronco embrionárias e o modelo canino}

Dentre todos os animais domésticos, o cão talvez seja o de maior interesse na medicina regenerativa. Isso porquê os cães são acometidos por diversas doenças homólogas a seres humanos (PATTERSON, 2000; SWITONSKI et al., 2004). Hatoya et al. (2006) coletaram embriões caninos em diferentes estágios (mórula e blastocisto) e cultivaram com LIF sobre MEF, porém nenhuma linhagem foi obtida a partir da mórula, apenas algumas foram estabelecidas a partir do blastocisto. As colônias apresentaram morfologia típica de CTE-like, capazes de formar corpos embrióides e se diferenciarem em neurônios, células miocárdicas e epiteliais.

Schneider et al. (2007) desenvolveram estudos semelhantes e reportaram o isolamento de CTE-like em meio acrescido de LIF; as demais capacidades foram semelhantes as descritas por Hatoya et al. (2006). Em 2008, Hayes et al. também usaram meios de cultivo acrescidos de LIF para isolar e manter CTE-like por 34 passagens. Wilcox et al. (2009) foi o primeiro estudo reportando o cultivo de tais células dependente de LIF e bFGF positivas a toda caracterização in vitro, porém ainda com desenvolvimento comprometido ao ser injetada em camundongos imunossuprimidos. Vaags et al. (2009) isolaram CTE a partir do blastocisto usando LIF e bFGF formando colônias compactas e semelhantes as murinas, mantidas por um número extenso de passagens e capazes de formar teratomas. Este trabalho representa um passo à frente na caracterização completa de tais células em cães. $\mathrm{O}$ trabalho mais recente relacionado a caracterização em cães, considerando a dificuldade no isolamento de células 
embrionárias verdadeiras, busca uma alternativa, avaliando o potencial de células do âmnio e do cordão umbilical e sua aplicação como células-tronco mesenquimais, concluindo que tais células são efetivas independente do período gestacional e podem ser uma fonte alternativa para a espécie na medicina regenerativa (URANIO et al., 2014). No quadro 1, podemos sumarizar os avanços nas pesquisas com células-tronco em animais domésticos, comparado ao estabelecimento em camundongos.

Quadro 1 - Semelhanças e diferenças entre CTE-like de cão, gato, suíno e equino comparadas as CTE de camundongo

\begin{tabular}{|l|l|l|l|l|l|}
\hline Caracterização & $\begin{array}{l}\text { CTE } \\
\text { Camundongo }\end{array}$ & $\begin{array}{l}\text { CTE-like } \\
\text { Cão }^{2}\end{array}$ & $\begin{array}{l}\text { CTE-like } \\
\text { Gato }^{3}\end{array}$ & $\begin{array}{l}\text { CTE-like } \\
\text { Suíno }^{4}\end{array}$ & $\begin{array}{l}\text { CTE-like } \\
\text { Equino }^{5}\end{array}$ \\
\hline Fosfatase alcalina & + & + & + & + & + \\
\hline OCT4 & + & + & + & + & + \\
\hline Corpo embrióide & Sim & Sim & Sim & Sim & Sim \\
\hline Teratoma in vivo & Sim & Sim & Não & Sim & Não \\
\hline Quimera & Sim & Não & Não & Sim & Não \\
\hline
\end{tabular}

${ }^{1}$ de acordo com Ginis et al., 2004, ${ }^{2}$ de acordo com Scheneider et al., 2010, ${ }^{3}$ de acordo com Yu et al., 2008, ${ }^{4} \mathrm{de}$ acordo com Brevini et al., 2008, ${ }^{5}$ de acordo com Guest; Allen, 2007.

Fonte: (Gonçalves et al., 2014)

\subsection{Pluripotência geneticamente induzida (Induced Pluripotent Stem Cell -IPSC)}

As células-tronco de pluripotência induzida são geradas a partir da expressão induzida de fatores de transcrição relacionados à pluripotência, permitindo que uma célula somática reverta sua condição diferenciada ao estado embrionário. Partindo-se deste princípio, surge o processo alternativo para obtenção de células-tronco, quando Takahashi e Yamanaka, estabeleceram uma técnica onde fatores de transcrição conhecidos no genoma eram incorporados às células somáticas de camundongos (2006) e humanos (2007): OCT3/4, SOX2, $K L F 4$ e $c-M Y C$ (representados pela sigla OSKM) sendo estes quatro fatores, suficientes para que fibroblastos fossem induzidos à pluripotência (induced pluripontent stem cells -iPSC). A descoberta de tal tecnologia foi fundamentada na hipótese de que a reprogramação nuclear é um processo conduzido por fatores que desempenham papel essencial na manutenção da pluripotência das células-tronco embrionárias (TAKAHASHI; YAMANAKA, 2006; YAMANAKA, 2008). 
A área da pluripotência induzida vem crescendo exponencialmente e com isso a corrida por eficiência, reprodutibilidade e segurança são aspectos decisivos para o sucesso da reprogramação. Estes podem ser determinados pelos métodos acessados para introdução de tais genes nas células somáticas (Figura 1).

Figura 1 - Esquema dos métodos de reprogramação

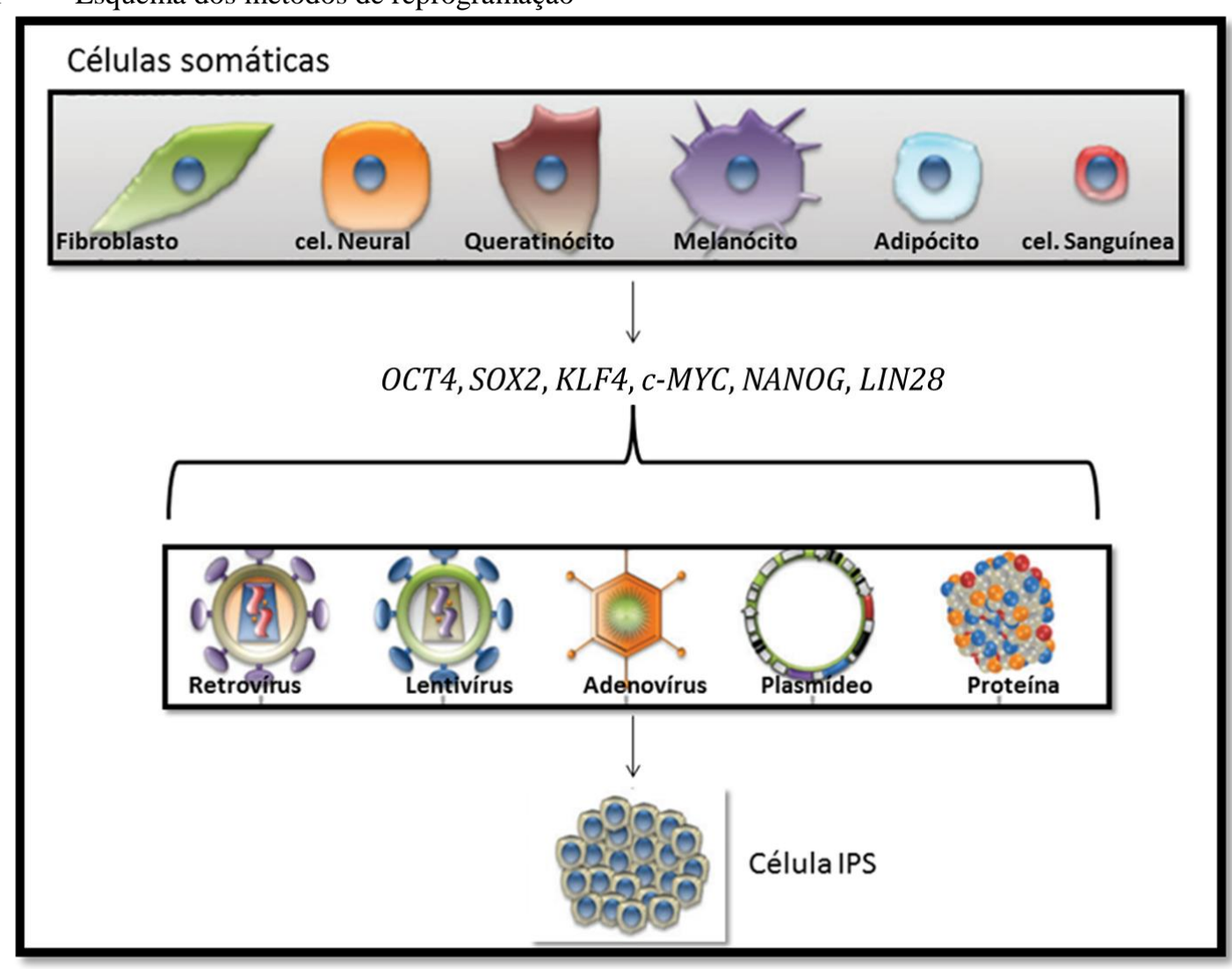

Fonte: retirado e adaptado de Han e Yoon (2011).

Legenda: Esquema representativo dos diversos métodos empregados na reprogramação celular utilizando fatores de transcrição em sistemas virais ou não.

Muitos trabalhos têm confirmado a repetitividade deste processo, com os mesmos vetores virais de transdução usados originalmente, gerando células de pluripotência induzida em diversas espécies, tais como: humanos, camundongos (TAKAHASHI; YAMANAKA, 2006; TAKAHASHI et al., 2007), macaco-rhesus (LIU et al., 2008), suínos (ESTEBAN et al., 2009), bovinos (SUMER et al., 2011), equinos (NAGY et al., 2011), coelhos (HONDA et al., 2010), ovinos (BAO et al., 2011) e em grandes felinos, como o leopardo (VERMA et al., 2012).

A geração de iPS em cães pode representar uma excelente alternativa diante de todas as dificuldades em isolar e cultivar CTE, até o momento 5 estudos são encontrados na 
literatura relatando a produção de iPS canina, três destes com uso de fibroblastos adultos (LEE et al., 2011; KOH et al., 2013; WHITWORTH et al., 2012), um a partir de fibroblastos embrionários (SHIMADA et al., 2010) e outro com fibroblasto testicular (LUO et al., 2011). Ambos, fibroblasto adulto ou embrionário, são reprogramáveis com uso de vetores retro ou lentivirais (SHIMADA et al., 2010) e fatores humanos (LEE et al., 2011; LUO et al., 2011) ou murinos (KOH et al., 2013), com exceção de uma linhagem que requer apenas LIF (LEE et al., 2011) todas as demais linhagens de iPS canina geradas, são dependentes de LIF e bFGF (SHIMADA et al., 2010; LEE et al., 2011; LUO et al., 2011; KOH et al., 2013). As células LIF-dependentes foram reprogramadas usando OSKM somado a LIN28 e NANOG (WHITWORTH et al., 2012), as demais foram reprogramadas apenas com OSKM (SHIMADA et al., 2010; LEE et al., 2011; LUO et al., 2011; KOH et al., 2013) Moléculas inibidoras (PD0325901, CHIR99021, A83-01) foram usadas durante a indução da pluripotência (SHIMADA et al., 2010) ou na manutenção das linhagens estabelecidas (KOH et al., 2013). A diferenciação in vitro foi demonstrada pela formação de corpos embrióides (LEE et al., 2011; LUO et al., $2011 \mathrm{KOH}$ et al., 2013) porém apenas dois estudo relatam a formação de tumores (LEE et al., 2011; KOH et al., 2013). Whitworth et al. (2012) descreveram tumores predominantemente de células germinativas-like.

As iPS são bastante promissoras quanto a sua aplicabilidade na terapia de doenças humanas (DIMOS et al., 2008; PARK et al., 2008; DARABI et al., 2012; NISHIMURA et al., 2013) e diante deste cenário, uma revisão publicada pela revista Cell Stem Cell intitulada: Rats, Cats, and Elephants, but Still No Unicorn: Induced Pluripotent Stem Cells from New Species, explora as inúmeras possibilidades de geração de IPSC (TROUNSON, 2009).

Desde então, inúmeras variáveis tem sido avaliadas: a redução dos fatores de transcrição usados, como $c-M Y C$ (NAKAGAWA et al., 2008) ou remoção do $S O X 2$ e adição de agente inibidor da cascata sinalizadora GSK-3 (glicogênio sintase quinase 3), sabe-se que o tratamento de colônias parcialmente reprogramadas com tais inibidores facilita a reprogramação completa (SILVA et al., 2008; LIN et al., 2009), remoção do KLF4 e do $c$ MYC adicionando-se ácido valpróico (HUANGFU et al., 2008). Alteração de vias específicas (MARSON et al., 2008; MAHERALI et al., 2007), uso de vetores não integrativos, ou seja, que não integram o cDNA dos fatores OSKM no genoma celular, como adenovírus (STADTFELD et al., 2008), reprogramação livre de vetores virais (OKITA et al., 2008; YU et al., 2009) e recentemente a reprogramação celular foi feita quimicamente com o uso de moléculas exógenas (HOU et al., 2013). 
Lembrando que tais variáveis não são eficazes como a integração lentiviral e que as células-tronco embrionárias verdadeiras ainda não estão bem caracterizadas nos carnívoros, dificilmente consegue-se estabelecer um padrão de comparação das células reprogramadas, razão pela qual são chamadas de semelhantes a células-tronco embrionárias (stem cell like), mas lembram em muito, os padrões de expressão gênica, assinatura epigenética e funcionalidade pluripotente (TELUGU et al., 2010).

5.5 A corrida pelo aumento da eficiência no processo de reprogramação e a importância dos fatores de transcrição

A massa celular interna (MCI) formada no início do desenvolvimento embrionário é caracterizada pela expressão de três reguladores de pluripotência fundamentais: OCT4, SOX2 e $N A N O G$, estes fatores específicos são requeridos para a manutenção da pluripotência in vivo ou in vitro (Figura 2).

Figura 2 - Expressão dinâmica de SOX2, OCT4 e NANOG durante o desenvolvimento murino

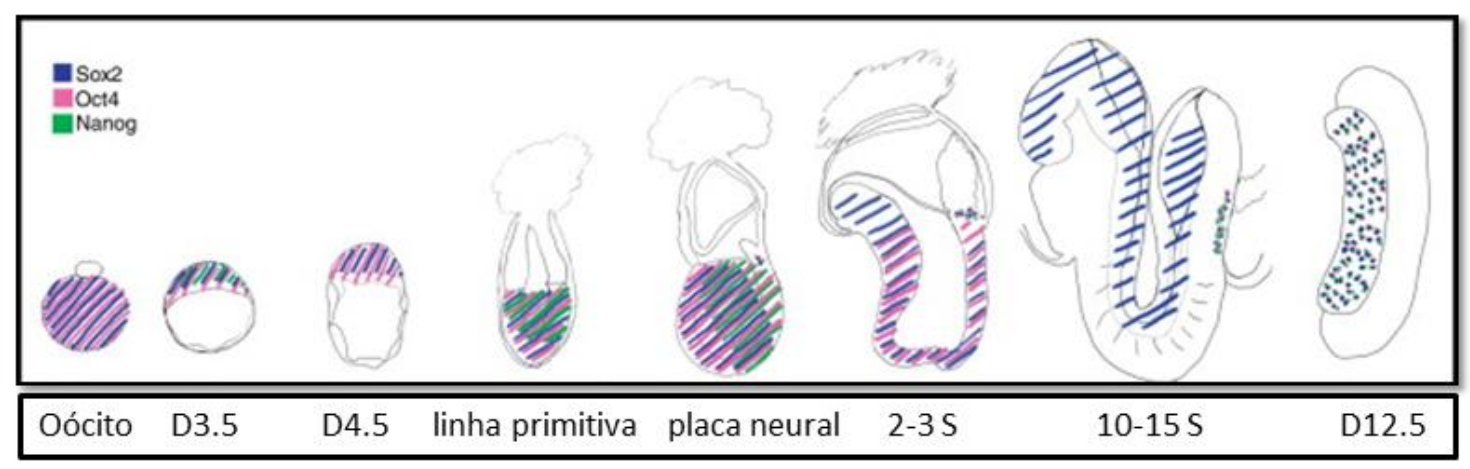

Fonte: retirado e adaptado de Festuccia et al. (2013).

Legenda: Expressão dinâmica de $S O X 2, O C T 4$ e $N A N O G$ durante o desenvolvimento murino. Considerando que mRNAs $O C T 4$ e $S O X 2$ são herdados maternalmente, o mRNA NANOG é detectado pela primeira vez em blastômeros no estágio de 8 células.

Os fatores de transcrição, em especial, OCT4 permanece como chave essencial, o componente necessário à mistura de reprogramação, que não é substituível por outros fatores, exceto por receptores nucleares NR5a1, NR5a2, e também por uma combinação de microRNAs miR-200c, miR-302s, e miR-369s (HENG et al., 2010; ANOKYE-DANSO et al., 2011). O fator OCT4 mostrou ser suficiente na indução da pluripotência (KIM et al., 2009). Seu papel central no processo de reprogramação têm levado pesquisadores a se perguntarem se os compostos que o ativam são capazes de aumentar a eficiência de reprogramação. 
O interesse precoce pelas interações entre a tríade $O C T 4$ - SOX2 - NANOG começou com a constatação de sua singularidade na manutenção da pluripotência (NICHOLS et al., 1998; MITSUI et al., 2003) e em seguida descobriu-se que SOX2 e OCT4 estão em uma via de mútua cooperação (BOYER et al., 2005; RIZZINO, 2009). A capacidade única de SOX2 cooperar com OCT4 em sítios de ligação seletivos no genoma, é fundamental para a reprogramação de células somáticas em células-tronco pluripotentes induzidas (iPSCs) (AKSOY et al., 2013).

A reprogramação celular é almejada nas mais diferentes áreas na busca do sucesso nas biotecnologias reprodutivas, assim, diversos autores empenham-se no conhecimento de todos os mecanismos envolvidos na pluripotência celular, porém o mecanismo exato continua obscuro. Duas questões parecem limitar a aplicação de iPSCs: a baixa eficiência de reprogramação e a integração de transgenes ao genoma somático (YAMANAKA, 2007), tais aspectos impuseram limitações importantes nas suas aplicações biomédicas e terapêuticas. Faz-se então, essencial o estabelecimento de procedimentos mais eficazes para a geração de iPSC.

Neste contexto, esforços consideráveis têm sido feitos para identificar compostos que possam melhorar a eficiência de reprogramação (HUANGFU et al., 2008; LYSSIOTIS et al., 2009). Pequenas moléculas capazes de remodelar a cromatina e deter o controle epigenético estão sendo investigadas ativamente quanto a seu efeito na reprogramação. Têm sido demonstrado que os inibidores da metiltransferase, inibidores de histonas desacetilase (HDAC) e inibidores de histona desmetilase podem aumentar os índices de eficiência da reprogramação (HUANGFU et al., 2008; MALI et al., 2010; ZHU et al., 2010). Moléculas que atuam sobre as vias de sinalização envolvidas na auto-renovação e pluripotência, tais como Wnt, TGF $\beta$ e MEK também aumentam tais índices (SILVA et al., 2008; ICHIDA et al., 2009; LIN et al., 2009). Ainda, a vitamina C e o Lítio foram reportados como capazes de aumentar a eficiência de reprogramação (ESTEBAN et al., 2010; WANG et al., 2011).

\subsection{A reprogramação induzida e os fatores cromossomais e epigenéticos}

Nos últimos anos, as células pluripotentes embrionárias e iPSCs tem sido uma importante ferramenta para estudos epigenéticos. Tal interesse pode ser explicado pela facilidade de gerar um grande número de iPs costumizadas para a medicina regenerativa, modelos de doenças e outras aplicações (YAMANAKA, 2007). 
A epigenética pode ser definida de forma clássica como modificações na cromatina ou no DNA que não alteram a sequência primária de nucleotídeos, que incluem mecanismos moleculares estáveis capazes de gerar um fenótipo que não altere o genótipo. Hoje é sabido que estes facilitam a complexa padronização necessária para assegurar o desenvolvimento inicial normal e a regulação estável de padrões apropriados à expressão gênica (MEISSNER, 2010).

A reprogramação epigenética do genoma ocorre em dois estágios fundamentais do desenvolvimento: durante a gametogênese e durante o início da embriogênese. O primeiro evento ocorre nas células primordiais germinativas (CPGs), onde marcas epigenéticas são apagadas e novas marcas são estabelecidas em alguns genes, durante momentos específicos do desenvolvimento, tanto antes quanto depois da fertilização. Após a fertilização, uma segunda onda de reprogramação ocorre, incluindo a desmetilação global (com exceção dos genes imprinted) seguida de uma de novo metilação para permitir a totipotência e subsequente diferenciação celular específica (RUVINSKY, 1999; REIK; DEAN; WALTER, 2001). Popp et al. (2010) através da técnica de sequenciamento por bissulfito demonstraram que as células germinativas em E13.5 possuem apenas de 5-20\% do DNA genômico metilado, confirmando que tais células reduzem de forma transitória o DNA metilado, sem efeitos adversos em sua viabilidade.

Com a tecnologia iPs, sabe-se que um ou vários fatores de transcrição podem converter uma célula em outra. Porém, os mecanismos pelos quais estes fatores exógenos substituem o estado epigenético existente e alteram este em um estado alternativa específico, sem passar por um desenvolvimento normal ou redefinição completa de todas as marcas ainda é em grande parte desconhecido. Os fatores-chave envolvidos na remodelação ainda não foram claramente identificados, e muitas perguntas sobre a dinâmica desse processo ainda não foram respondidas (MIKKENSEN et al., 2008).

Em estudos que investigam dados de expressão gênica e mapeamento epigenético, encontra-se uma forte relação sobre a expressão de genes em células pluripotentes (MIKKENSEN et al., 2008). Estes podem ser subdivididos em duas categorias: o primeiro inclui genes tais como LIN28, SOX2 e FGF4, que são reprimidos por H3K27; o segundo inclui os genes $O C T 4, N A N O G$ e $D P P A$, que são reprimidos pela metilação do DNA, deixando clara a importância de se conhecer a fundo tais mecanismos epigenéticos que regem a indiferenciação de células somáticas. $O$ estudo aprofundando de tal mapeamento epigenético é neste momento da ciência essencial para os próximos avanços (MEISSNER, 
2010). Delineando onde os erros de expressão ocorrem, gerando células reprogramadas com perfis epigenéticos semelhantes aos encontrados em células-tronco embrionárias.

A instabilidade genômica em células de pluripotencia induzida pode ser causada por diversas razões, como mutações pré-existentes nos fibroblastos reprogramados, integração viral que pude induzir danos no DNA ou stress replicativo por expansão in vitro. Já foram relatadas incidência de mutações como a variação no número de copias (CNVs) (HUSSEIN et al., 2011) e ainda o polimorfismo em um único nucleotídeo (SNPs) (GORE et al., 2011) no genoma de células iPS quando comparadas a CTE.

Já as alterações cromossomais, são avaliadas de forma citogenética, que é a ciência que estuda os cromossomas normais e anormais. Cada espécie é caracterizada por um dado número de cromossomos que pode ser reconhecido por sua morfologia, estes são organizados de acordo com esquemas de classificação padrão para as respectivas espécies. Os cães e os seres humanos compartilham uma variedade de doenças genéticas, incluindo câncer. Assim, o cão tornou-se um modelo cada vez mais importante para as doenças genéticas. No entanto, as análises citogenéticas de células caninas são complicados pelo cariótipo complexo do cão. Apenas 15 anos atrás, um esquema de classificação padrão para o cariótipo canino completo foi criado. Diversos estudos tem mostrado que tumores caninos são comparáveis a tumores humanos, sendo muitas vezes caracterizados por aberrações cromossômicas clonais, que podem ser usados como marcadores de diagnóstico e de prognóstico (REIMANN-BERG et al., 2012).

A construção de mapas genômicos para os mamíferos vêm recebendo mais atenção nos últimos anos, apesar de humanos e murinos terem recebido mais atenção do que qualquer outra espécie. Muitos esforços tem sido feitos para a produção de mapas de espécies economicamente importantes, como bovinos e suínos, e mais recentemente colaborações têm trabalhado no estabelecimento de tais mapas para espécies domésticas como cães e cavalos. A colaboração internacional DogMap foi estabelecida em 1993 desenvolvendo marcadores de baixa resolução (REIMANN-BERG et al., 2012).

Nos cães, todos os 38 pares autossômicos são acrocêntricos com uma discreta e gradual diminuição de tamanho. O maior cromossomo é o X estimando-se ter $137 \mathrm{Mb}$ de tamanho comparado com Y com apenas $27 \mathrm{Mb}$ (LANGFORD et al., 1996). Com a similaridade no tamanho dos cromossomos fica difícil a identificação por colorações convencionais ou o estabelecimento de qualquer cariotipagem padronizada.

O primeiro trabalho restrito aos 21 pares autossômicos e os cromossomos sexuais foi publicado em 1996 por Switonski et al, mantendo-se a dificuldade de identificar os 17 pares 
remanescentes, fez-se necessário o desenvolvimento de sondas fluorescentes e específicas que se ligavam aos cromossomos por hibridização (FISH). Em 1999 o grupo do Dr. Breen estabeleceu sondas para cada um dos 38 pares de cromossomos bem como para os cromossomos sexuais, aumentando as possibilidades de análises e avaliações cromossomais em tal espécie. Koh et al. (2013) tentaram determinar o verdadeiro grau de instabilidade cromossomal em iPs canina utilizando a hibridização FISH e detectaram anomalias semelhantes as encontradas em camundongos e humanos. 
Capítulo 6: Avaliação do processo de reprogramação induzida a partir de vetores epissomais ou retrovirais 


\section{AVALIAÇÃo do PROCESSO DE REPROGRAMAÇÃO INDUZIDA A PARTIR DE VETORES EPISSOMAIS OU RETROVIRAIS}

Aqui são descritos os experimentos desenvolvidos na Universidade da Carolina do Norte, NCSU, durante o período de agosto a novembro de 2012 em doutorado sanduíche. Nesta parceria, objetivou-se comparar a geração de iPS a partir da metodologia retroviral, já estabelecida e padronizada, com a metodologia epissomal, ainda inédito para a espécie, na tentativa de compreender tal processo. Sabe-se que a busca por metodologias mais eficazes na produção de iPS tem sido o foco de muitos grupos desde sua descoberta em 2006. O estabelecimento de linhagens epissomais poderia descartar o advento da integração viral e nos levar um passo à frente no uso de tais células para terapia celular. Este capítulo foi apresentado como resumo no IFPA 2013 (Anexo A).

Natalia J. Gonçalves, Sehwon Koh, Fabiana F. Bressan, Daniele S. Martins, Flávio V. Meirelles, Jorge Piedrahita, Carlos E. Ambrósio. Canine IPSC generation with Non-Integrative vectors. Placenta n. 34, v. 9, p. A66, 2013. (DOI: 10.1016/j.placenta.2013.06.182).

A produção de IPS não transgênica é altamente desejável, especialmente em modelos animais, como o canino. Fibroblastos de pele de cães foram cultivados e mantidos em DMEN/F12. Os vetores epissomais contendo os fatores de transcrição murino (OCT3/4, SOX2, KLF4 e c-MYC - OSKM) e o vetor epissomal somado a cada fator OSKM foram usados para gerar linhagens de células ciPSC independentes. As células foram transfectadas, após protocolo de nucleofecção Amaxa, duas vezes durante oito horas, e então os vetores foram removidos e o meio de cultivo substituído. No dia 6 pós-infecção, as células foram replaqueadas em MEFs, no dia seguinte, o meio de cultura foi substituído por mTESR. As culturas celulares foram analisados após cada tratamento e comparado com as células transfectadas com o vetor epissomal somente. Observou-se alterações morfológicas apenas nas células acrescidas de c-MYC, com formações semelhantes a colônias iPS, sendo que estas apresentaram atividade de fosfatase alcalina (AP). Estes resultados preliminares mostram um caminho para a geração de iPSC livre de integração, aumentando o potencial terapêutico dessas células. 


\subsubsection{Cultivo celular}

Fibroblastos adultos provenientes da epiderme foram coletados de cães saudáveis com aproximadamente 3 anos de idade, da raça Beagle. Estes foram mantidos em DMEN/F12 com $10 \%$ de soro fetal bovino e $0.1 \%$ de gentamicina (Cellgro). Células PLAT-GP e MEFS foram mantidas no mesmo meio de cultivo. As células reprogramadas foram mantidas com mTESR (Stemcell, Vancouver, BC, Canada) e as colônias repicadas mantidas em DMEM/F12 (Cellgro), com 20\% de KSR (KSR, Life Technologies, Carlsbad, CA, USA), 2 mM L-Alanil-L-Glutamina (Cellgro), $0.1 \mathrm{mM}$ aminoácido não essencial (NEAA, Cellgro), $0.1 \mathrm{mM}$ 2-mercaptoetanol (BME, Sigma) suplementado com FGF2 (10 ng/ml, Stemgent, Cambridge, MA, USA), hLIF (103 unit/ml, GenScript, Piscataway, NJ, USA) ou ambos. Os inibidores PD0325901 (0.5 $\mu \mathrm{M})$, (GSK3B) e CHIR99021 (3 $\mu \mathrm{M})$ foram adicionados como suplementação ao meio iPS completo. Todos os experimentos foram aprovados pelo Institutional Animal Care and Use Committee sob número de protocolo 10-056-B.

\subsubsection{Monocamada de cultivo (MEFS)}

MEFs foram obtidas a partir do dia 13-14 de camundongos C57BL/6 e as células isoladas a partir dos fetos foram usadas em passagens 1-3 como monocamada de cultivo. As MEFs foram tripsinizadas e irradiadas com raios gama com 5000 rad e plaqueadas na concentração de $8 \times 10^{5}$. 


\subsubsection{Produção Epissomal}

\subsubsection{Escolha dos plasmídeos e enzimas de restrição}

Os plasmídeos epissomais foram obtidos da Addgene e clonados com os fatores (OCT4, SOX2, NANOG, Lin28, $c-M Y C$ e $K L F 4$ ) no vetor oriP/EBNA1 usando IRES 2 para coexpressão (Figura 3). Os plasmídeos foram inoculados em E. coli em placas de cultivo com meio LB ágar (Luria-Bertani) e mantidas por aproximadamente 16 horas a $37^{\circ} \mathrm{C}$. A colônia contendo o plasmídeo de interesse foi selecionada e purificada por Maxi Prep (Qiagen) de acordo com as instruções do fabricante. Cada plasmídeo foi digerido com a enzima de restrição ECOR1 (Figura 4), para confirmar a presença dos fatores, em seguida os plasmídeos foram quantificados, aliquotados e armazenados em freezer $-80^{\circ}$ até o momento do uso.

Figura 3 - Mapa do vetor oriP/EBNA 1

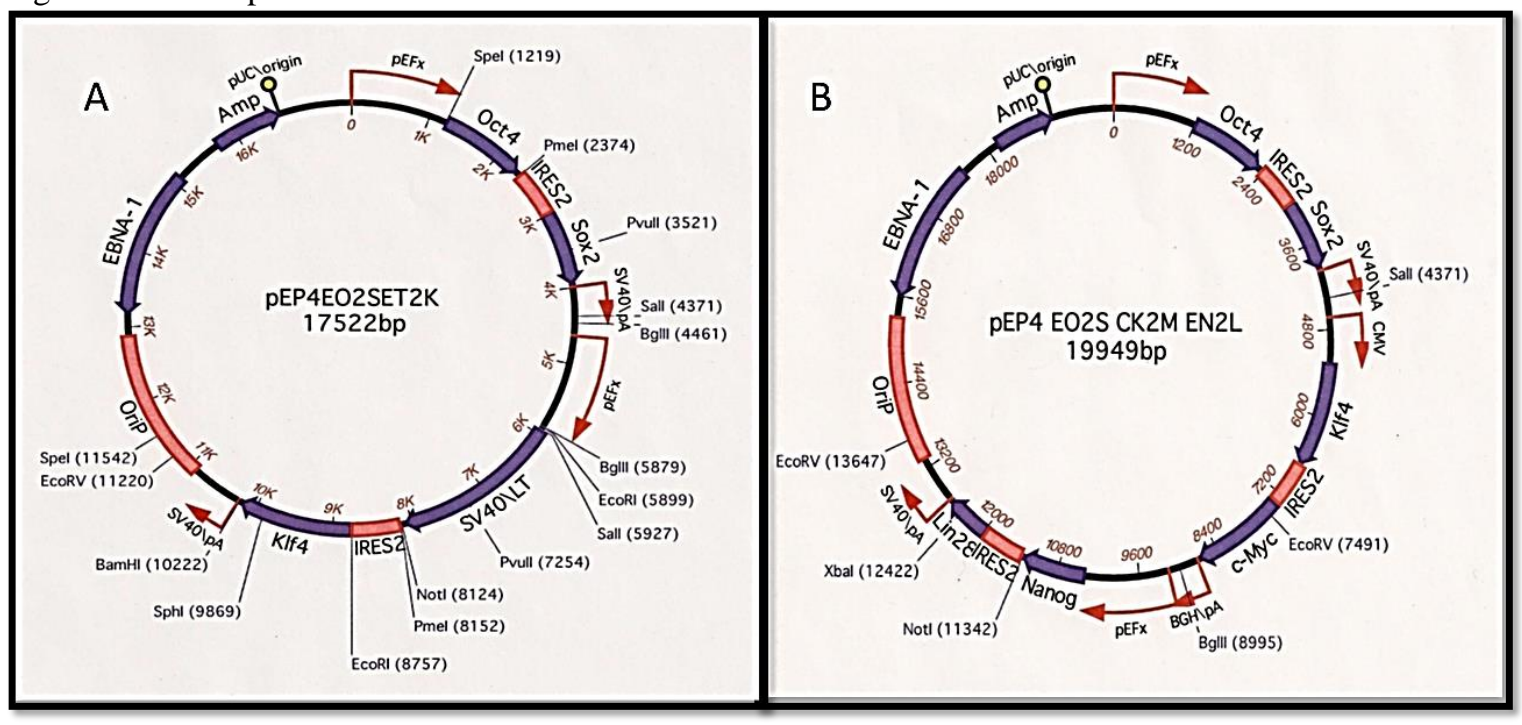

Fonte: Retirado e adaptado Yu et al. (2009).

Legenda: Mapa do vetor oriP/EBNA 1 (A) usando IRES2 para coexpressão (B) fornecidos pela Addgene. 
Figura 4 - Gel de agarose mostrando os fragmentos do plasmídeo após digestão enzimática

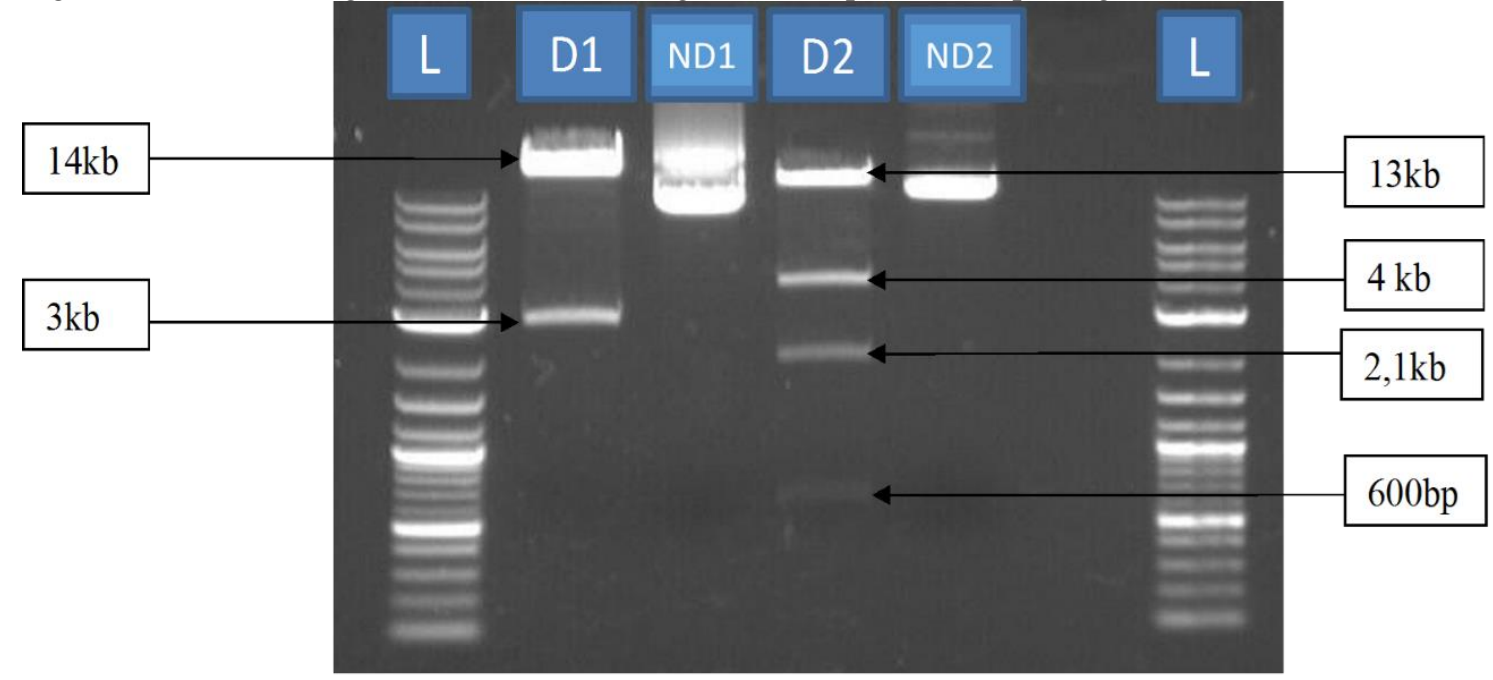

Fonte: (Gonçalves, N.N., 2015)

Legenda: Gel de agarose mostrando os fragmentos de DNA dos plasmídeos após reação com a enzima de restrição ECOR1, o plasmídeo 1 foi cortado em dois pedaços com $14 \mathrm{~kb}$ e com $3 \mathrm{~kb}$. O segundo plasmídeo foi cortado em 5 pedaços com $13 \mathrm{~kb}, 4 \mathrm{~kb}, 2.1 \mathrm{~kb}, 600 \mathrm{pb}$ e $30 \mathrm{pb}$ (o último fragmento é de difícil visualização por ser muito pequeno). L (letra ou padrão), D (digerido), ND (não digerido), respectivamente para o plasmídeo $1 \mathrm{e}$ 2.

\subsubsection{Nucleofecção}

Para os plasmídeos epissomais foi feito o protocolo de nucleofecção com Amaxa de acordo com instruções do fabricante, a tecnologia Nucleofector ${ }^{\mathrm{TM}}$ é o procedimento de nucleofecção mais eficaz e é essencial para que o DNA de interesse seja carreado para dentro do núcleo. O procedimento com os plasmídeos epissomais foi seguido de controle positivo com plasmídeo GFP (pEGFP-C1) para comprovação da eficácia do procedimento (Figura 5).

Figura 5 - Fibroblastos caninos após a inserção do vetor epissomal por nucleofecção

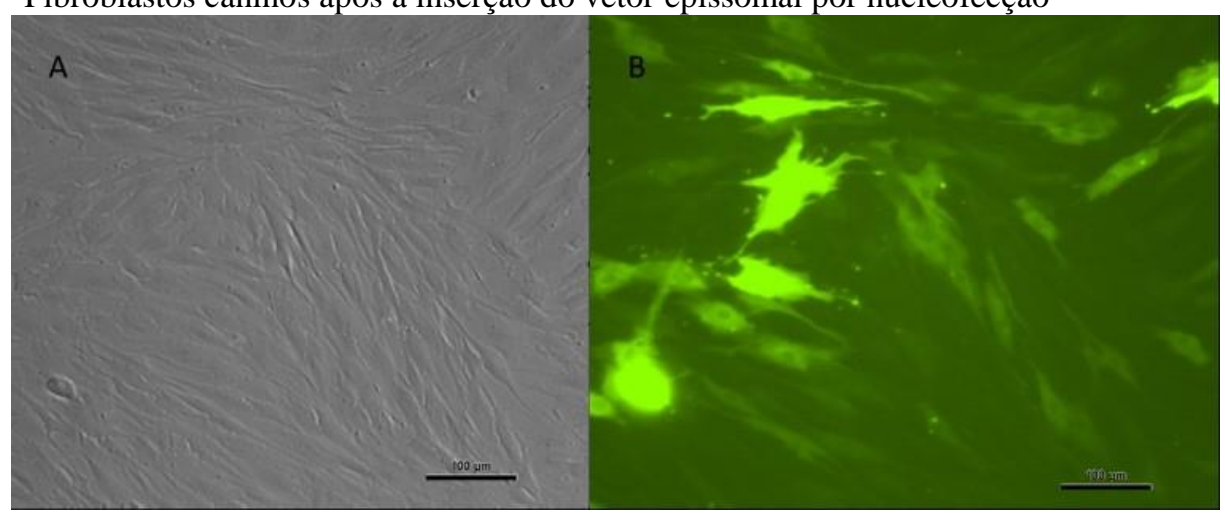

Fonte: (GONÇALVES, N. N., 2015)

Legenda: Fibroblastos caninos após a inserção do vetor epissomal por nucleofecção (A) e o plasmídeo GFP como controle positivo (B) comprovando a eficácia do protocolo. 


\subsubsection{Produção retroviral}

Células PLAT-GP foram plaqueadas na concentração de $8 \times 10^{6}$ e cultivadas overnight. No dia seguinte, os vetores retrovirais pMXs contendo os fatores murinos OCT3/4, $K L F 4, S O X 2$ e $c-M Y C$ foram transfectados com o vetor auxiliar pCI-VSV-G envelope com o auxílio do reagente Fugene 6 (Roche, Florence, SC, USA), conforme descrito por Takahashi et al. em 2007. A eficiência da transfecção foi monitorada com o vetor repórter pMXs-mRFP1 (Figura 6) e o sobrenadante contendo a produção viral só foi coletado quando a taxa de eficiência da transfecção foi maior que $70 \%$. O sobrenadante viral foi coletado duas vezes, com 48 e 72 horas pós-transfecção, e filtrado em membrana $0.45 \mu \mathrm{m}$. O sobrenadante filtrado foi usado para infectar os fibroblastos de cão após suplementação com polibreno $(2 \mu \mathrm{g} / \mathrm{ml}$, Sigma, St. Louis, MO, USA), ou aliquotado e armazenado a $-80^{\circ} \mathrm{C}$ até o uso.

Figura 6 - Células PLAT (A) com pMXs-mRFP1 usado para produção viral após 72 horas de transfecção

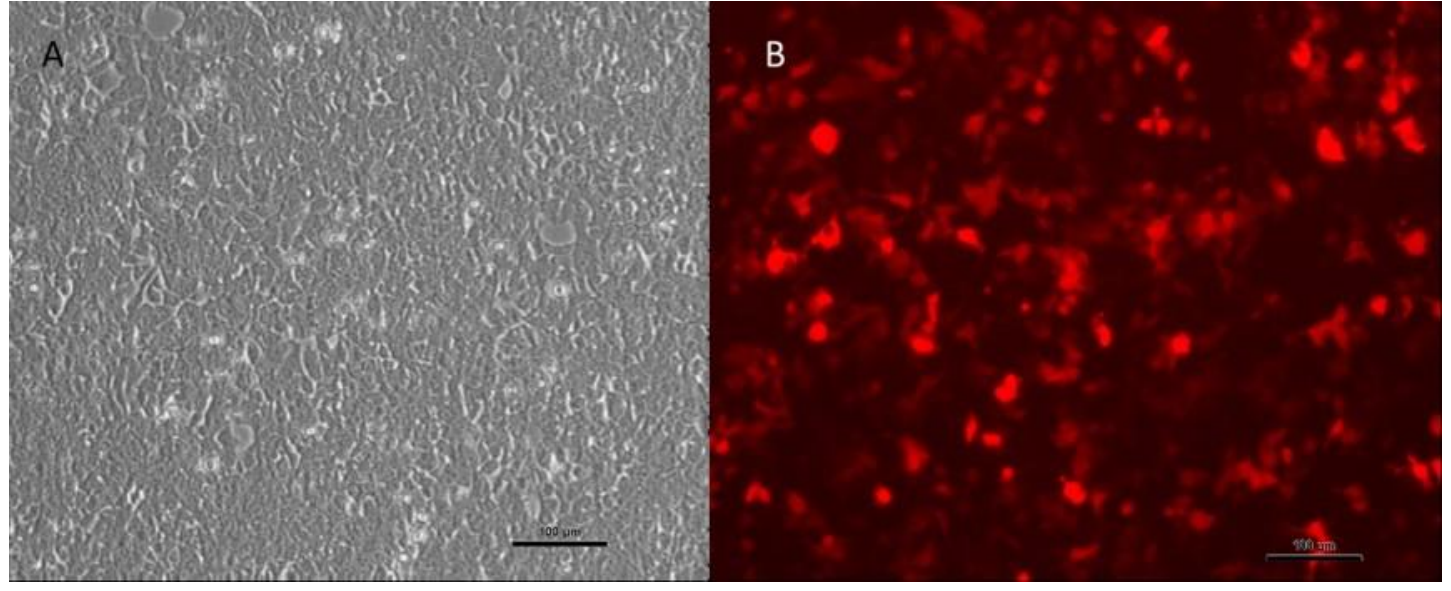

Fonte: (GONÇALVES, N. N., 2015)

Legenda: Células PLAT (A) com pMXs-mRFP1 usado para produção viral após 72 horas de transfecção. Fluorescência do vetor repórter fotografado em UV (B) comprovando a alta taxa de transfecção. 20X. Exposição na luz UV 200ms.

\subsubsection{Geração de células de pluripotência induzida por sistema retroviral}

Fibroblastos foram plaqueados na concentração de $8 \times 10^{5}$ um dia antes do processo de infecção retroviral e epissomal. As células foram transfectados por 8 horas, então o vírus foi removido e as células receberam meio novo para recuperação. Este procedimento foi repetido no dia seguinte. Após 6 dias as células foram replaqueadas em poços com MEF e suplementadas com 
meio mTESR1 que contém os nutrientes necessários para as iPSCs. O meio foi trocado a cada 48 horas. As colônias foram repicadas manualmente e expandidas em meio contendo os inibidores

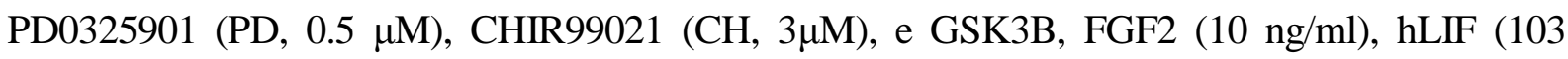
unidades/ml, LIF) ou ambos FGF2 e LIF. As colônias foram repicadas manualmente a cada 4 dias.

\subsubsection{Delineamento experimental}

O processo de transfecção retroviral, já estabelecido no grupo, foi usado como controle positivo para a infecção epissomal, um processo ainda pouco usado e não padronizado, e ainda comparando ambos (retroviral e epissomal) ao o comportamento da reprogramação epissomal associada a fatores de pluripotência (OCT4, SOX2, KLF4 e $c-M Y C)$, esperando-se observar se tal associação aumentaria a eficácia de reprogramação, conforme delineamento experimental abaixo (Figura 7).

Figura 7 - Diagrama mostrando delineamento experimental 1

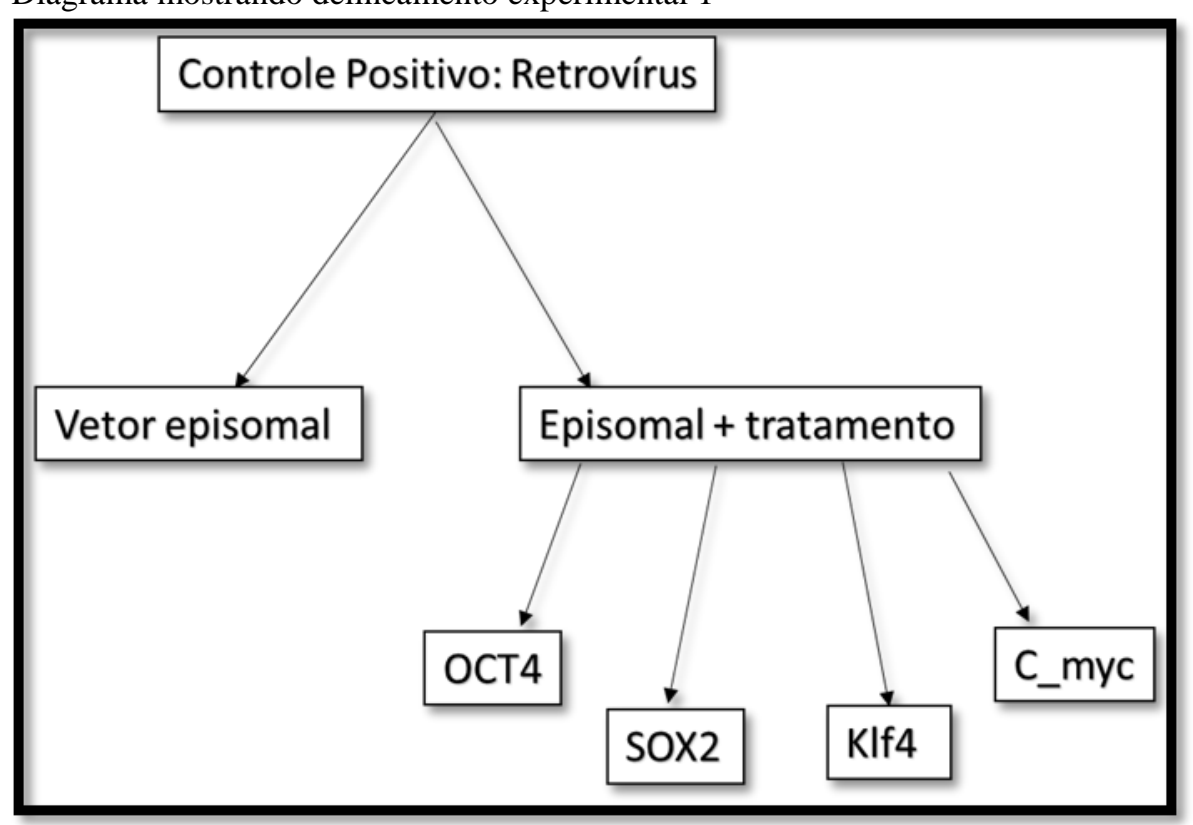

Fonte: (GONÇALVES, N. N., 2015)

Legenda: Diagrama mostrando delineamento experimental. A infecção retroviral foi usada como controle, comparada a transfecção epissomal e ainda epissomal com os fatores pluripotentes em separado. 


\subsubsection{Fosfatase alcalina - caracterização in vitro}

Para o teste da fosfatase alcalina as colônias iPS foram tratadas com VECTASTAIN ABC-AP kit (VECTOR Laboratories, Burlingame, CA, USA) de acordo com instruções do fabricante. Após a coloração, três campos (microscopia de ampliação 20X) de cada tratamento foram selecionados aleatoriamente e as colônias positivas foram contadas.

\subsection{Resultados}

Os fibroblastos transduzidos com vetor retroviral começaram a apresentar alterações morfológicos semelhantes a colônias após 10 dias em MEFS (Figura 8) e os fibroblastos reprogramados com o vetor epissomal, mostraram tais formações após 15 dias, apenas para aquelas acrescidas de $c-M Y C$ (Figura 9), as colônias foram acompanhadas e fotografadas, porém, devido ao curto período neste grupo da Universidade da Carolina do Norte, não foi possível a continuação e manutenção destas colônias bem como sua caracterização completa.

Figura 8 - Fibroblastos em processo de reprogramação com vetor murino retroviral

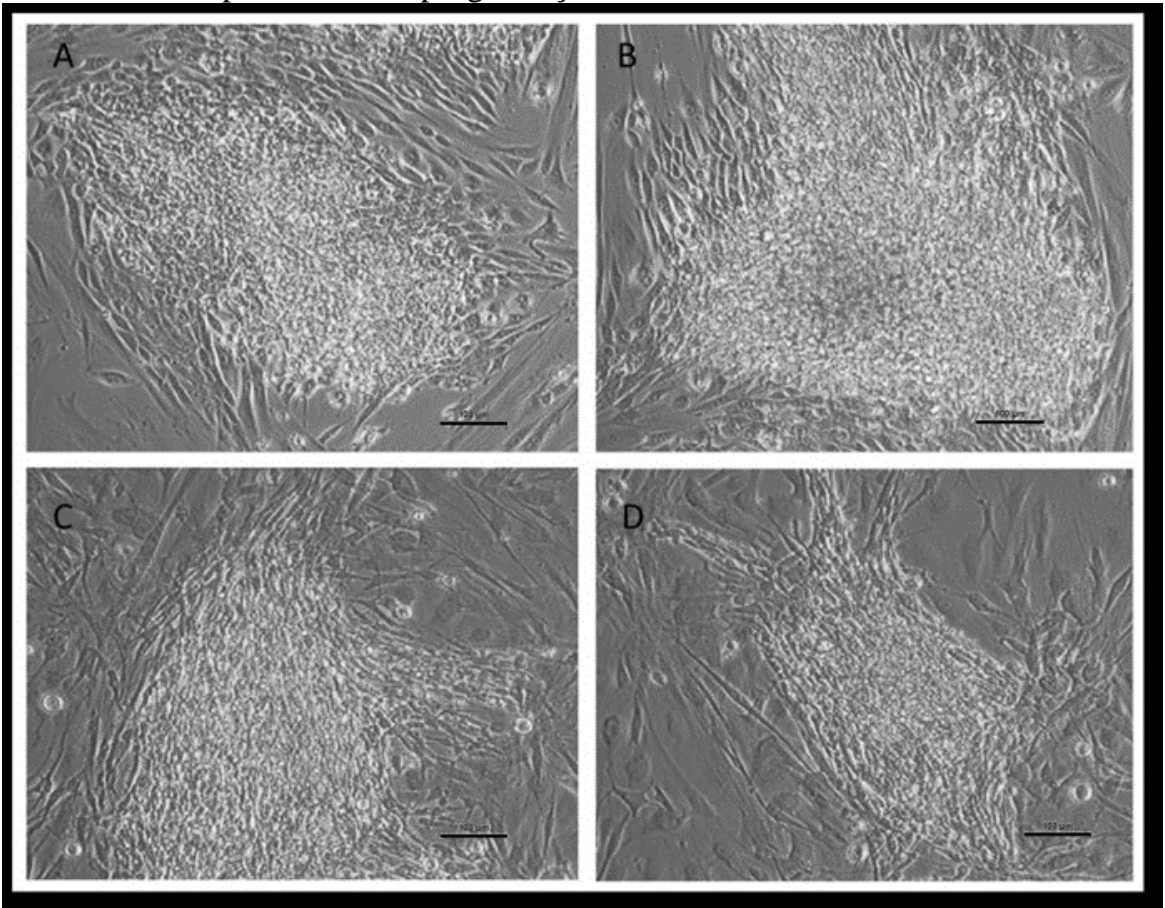

Fonte: (GONÇALVES, N. N., 2015)

Legenda: Fibroblastos em processo de reprogramação com vetor murino retroviral, A, B, C e D mostrando 4 colônias em fase inicial, 10 dias pós infecção. 
Figura 9 - Fibroblastos caninos 15 dias pós reprogramação com vetor epissomal apenas, e com tratamentos dos fatores
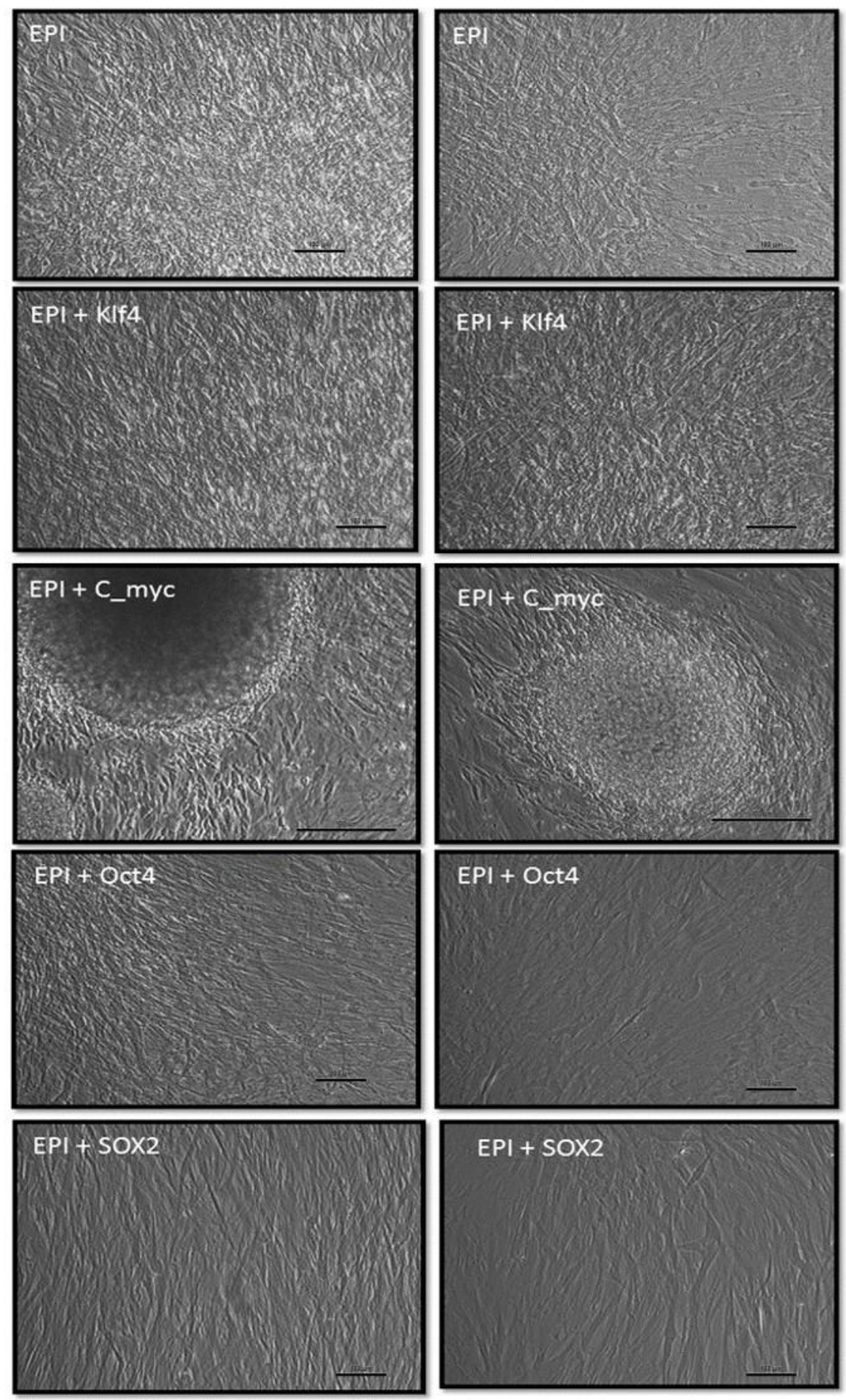

Fonte: (GONÇALVES, N. N., 2015).

Legenda: Fibroblastos caninos 15 dias pós reprogramação com vetor epissomal apenas, e com tratamentos dos fatores murinos KLF4, c-MYC, OCT4 e SOX2. Observar a formação de colônias apenas na associação epissomal + $c-M Y C$. 
As colônias observadas no protocolo epissomal $+c-M Y C$ foram repicadas manualmente (Figura 10) e mantidas com LIF, FGF2, ou ambos. Sua manutenção foi possível por 2 passagens, após este período as células regrediram e não apresentaram mais morfologia típica.

Figura 10 - Colônias formadas a partir da combinação epissomal $+c-M Y C$

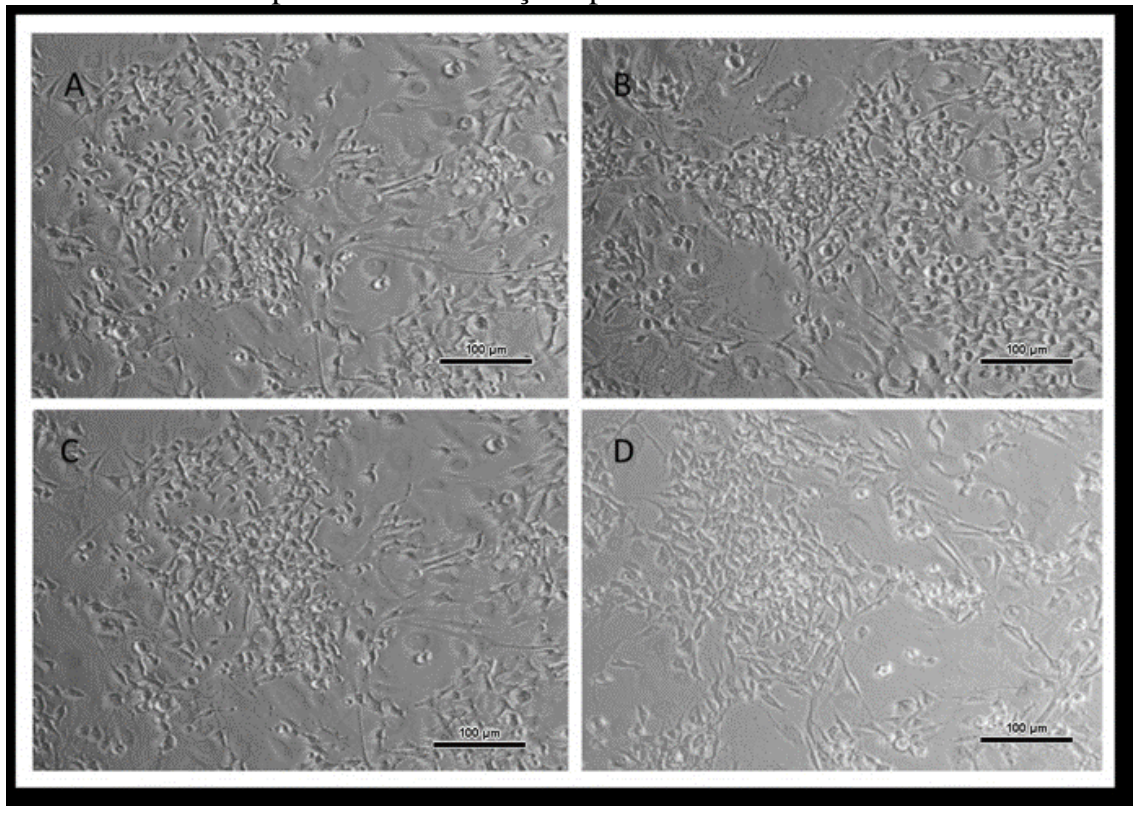

Fonte: (GONÇALVES, N. N., 2015).

Legenda: Colônias formadas a partir da combinação epissomal $+c-M Y C$ pós repique, expandidas com 2i, LIF, bFGF ou ambos em associação, sem diferenças morfológicas aparentes de tais suplementações.

As colônias provenientes desta combinação foram as únicas a mostrar forte atividade de fosfatase alcalina, dando suporte a conformação morfológica de colônias pluripotentes (Figura 11).

Figura 11 - Colônias geradas a partir da combinação epissomal + c-MYC, mostrando forte atividade de fosfatase alcalina

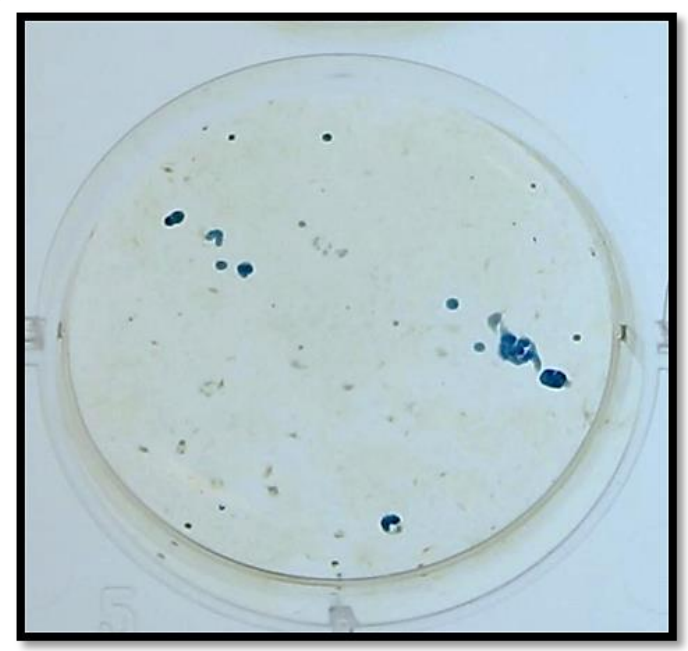

Fonte: (GONÇALVES, N. N., 2015).

Legenda: Colônias geradas a partir da combinação epissomal $+c-M Y C$, mostrando forte atividade de fosfatase alcalina durante a reprogramação. Colônias negativas versus positivas destacadas com a coloração azul. 


\subsection{Discussão}

As células de pluripotência induzida tem centenas de aplicações na biologia básica, desenvolvimento de medicamentos e transplante. Tal processo está associado a vetores que se integram no genoma, Takahashi et al. (2007); Shimada et al. (2010) e Withworth et al. (2012) são apenas alguns exemplos de grupos que descrevem tal processo de integração viral com sucesso. Porém como consequência podem ocorrer mutações advindas desta integração, limitando sua aplicação clínica. Os métodos iniciais de reprogramação empregam vetores virais em que tanto a estrutura do vetor como o transgene são permanentemente integrados ao genoma da célula (TAKAHASHI et al., 2007). As mutações consequentes de tal integração interferem no comportamento de tais células, assim como a expressão do transgene pode influenciar na diferenciação de linhagens específicas ou mesmo resultar em tumorogênese (OKITA et al., 2007).

O processo que envolve vetores que não se integram ao genoma ainda é pouco padronizado e pouco eficaz, exigindo um maior tempo de exposição aos fatores de reprogramação (OKITA et al., 2007; STADTFELD et al., 2008).

Yu et al. (2009) reportaram células iPs humanas completamente livres de vetores e sequências transgênicas, geradas com uma única transfecção derivada de vetores epissomais oriP/EBNA1 (vírus do Epstein-Barr antígeno nuclear 1), estes são adequados para a reprogramação em células somáticas humanas, uma vez que podem ser transfectadas sem a necessidade de envelope viral, e podem ser subsequentemente removidos a partir do cultivo celular sem seleção por drogas.

Os resultados mais positivos obtidos neste experimento foram da associação do vetor epissomal com o fator $c-M Y C$, o que pode ser explicado pois este fator promove o rápido desenvolvimento celular. A expressão de $c-M Y C$ pode regular negativamente a expressão de genes específicos de fibroblastos e induzir o contexto molecular do estado embrionário. Além disso $c$ MYC regula diversos miRNAs que promovem a tumorogênese e atuam na manutenção da pluripotência das células embrionárias (LIN et al., 2009a; LIN et al., 2009b). Assim, c-MYC estabelece o contexto molecular no início de reprogramação, não apenas através da interação direta com as regiões promotoras dos genes alvo, mas também ao exercer efeitos inibidores sobre redes somáticas através da regulação de miRNAs.

O período de 3 meses utilizado no doutorado sanduiche, para o desenvolvimento de tais experimentos, não foi suficiente para a reprodutibilidade dos experimentos, porém, os resultados alcançados são inéditos para reprogramação em canídeos e nos permitem sugerir que a 
reprogramação sem a integração viral, é possível, aumentando as chances do uso de tais linhagens na terapia celular, sem a integração viral e as implicações terapêuticas desta transgenia. 
Capítulo 7: Análise da expressão de fatores exógenos relacionados à pluripotência no modelo canino 


\section{ANÁLISE DA EXPRESSÃO DE FATORES EXÓGENOS RELACIONADOS À PLURIPOTÊNCIA NO MODELO CANINO}

O segundo experimento visou avaliar e descrever o comportamento dos fatores de transcrição quando introduzidos nos fibroblastos caninos em separado, podendo inferir diferenças de comportamento celular associado a cada um dos fatores quanto à reprogramação. Dois fatores de transcrição: OCT4 e SOX2, acoplados a repórteres fluorescentes, foram transduzidos, individualmente ou combinados, usando o sistema lentiviral. Linhagens transgênicas estáveis foram obtidas e as células caninas mostraram correta integração e alta expressão dos fatores humanos OCT4 e SOX2.

Os resultados obtidos neste experimento foram enviados para o 7th ISCFR 2012, o resumo expandido foi considerado inédito e inovador e o grupo foi convidado para apresentação oral deste trabalho e publicação de artigo completo na edição especial da revista Reproduction in Domestic Animals (Anexo C).

Gonçalves, N. J. N.; Bressan, F.; Souza, A.; Martins, D. S.; Miglino, M. A.; Meirelles, F. V.; Perecin, F.; Ambrosio, C. E. Canine fibroblasts expressing human transcription factors: What is in the route for the production of canine induced pluripotent stem cells. Reproduction in Domestic Animals, v. 47, n. 6, p. 1-5, 2012. 
7.1 Material e Métodos

\subsubsection{Derivação de linhagem de fibroblasto fetal canino}

A linhagem de fibroblasto canino foi derivada do banco de células-tronco animais do nosso grupo (GDTI/FZEA-USP), e foram obtidas a partir de fetos provenientes de histerectomias eletivas. Após a remoção da cabeça e órgãos, o tecido fetal foi desagregado em pedaços menores e então estes foram digeridos com a enzima tripsina por $3 \mathrm{~h}$. $\mathrm{O}$ resultado da digestão foi lavado e plaqueado em meio DMEM suplementado com soro fetal bovino e antibióticos. Quando subconfluentes, o cultivo foi congelado ou repicado para a continuação dos experimentos.

\subsubsection{Preparação dos vetores lentivirais}

Os vetores lentivirais utilizados neste experimento para o gene OCT4-vexGFP e para SOX2-mCitrine foram os mesmos reportados por Papapetrou et al. (2009) (Figura 12)

Figura 12 - Mapa dos vetores lentivirais OCT4-vexGFP e SOX2-mCitrine

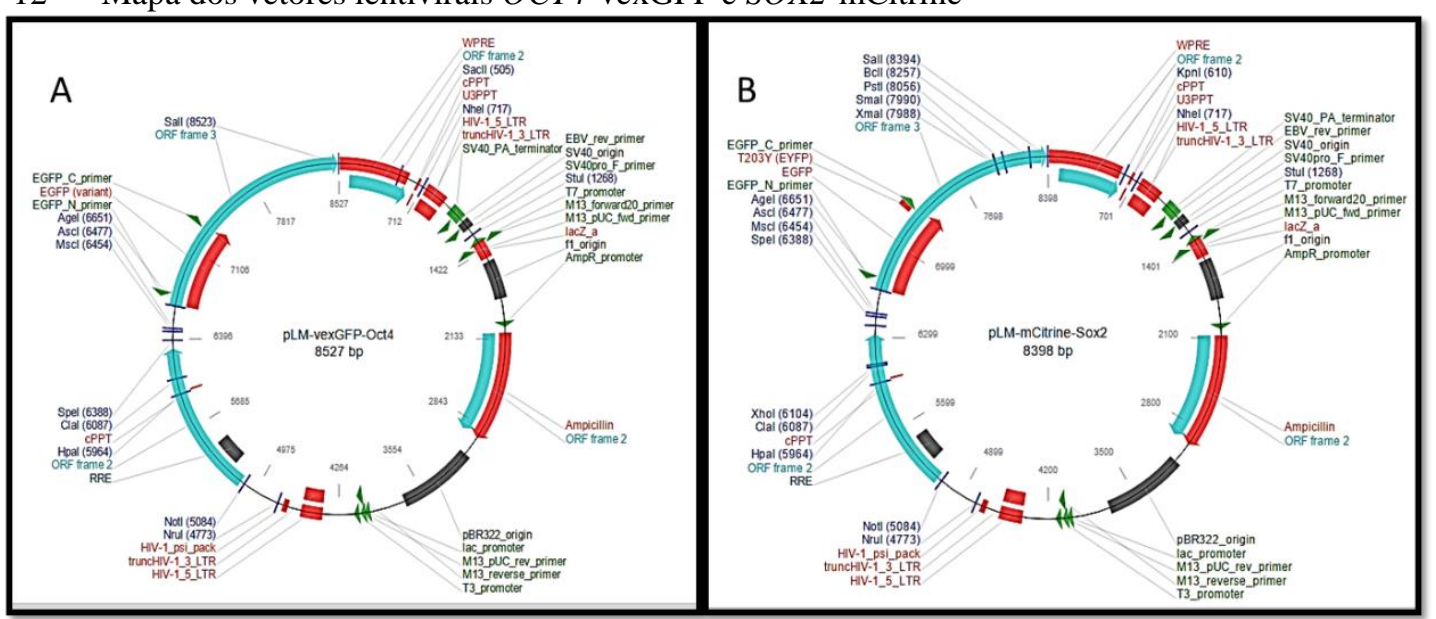

Fonte: Imagens adaptadas Addgene (www.addgene.org)

Legenda: Mapa dos vetores lentivirais OCT4-vexGFP (Addgene 22240) e SOX2-mCitrine (Addgene 23242). 


\subsubsection{Preparação dos plasmídeos}

Os plasmídeos foram providos em stabs bacterianos, as culturas foram inoculadas em placas de ágar LB (Luria-Bertani) e incubadas à $37^{\circ} \mathrm{C}$ por 16 horas. Uma colônia foi isolada para cada plasmídeo de interesse e esta foi preparada com o kit MaxiPrep (Qiagen) de acordo com o fabricante.

\subsubsection{Produção lentiviral}

Para a produção viral, células 293FT foram transfectadas com cada plasmídeo de interesse utilizando o reagente lipofectamina, plasmídeos empacotadores, e o envelope VSVG (Figura 13). O sobrenadante (meio de cultivo) foi recuperado após $72 \mathrm{~h}$ da transfecção, filtrado em filtros de seringa de $0,45 \mathrm{~nm}$, concentrado através da ultracentrifugação, aliquotado e estocado em freezer $-80^{\circ} \mathrm{C}$. Para a produção de tais linhagens estáveis, fibroblastos de cão foram cultivados $\left(2 \times 10^{5}\right.$ células por poço de placa de 6 poços $)$ e transduzidos com os lentivírus na presença de $6 \mu \mathrm{g} / \mathrm{ml}$ de polibreno (Sigma) utilizando $1 \mathrm{ml}$ de sobrenadante viral concentrado e filtrado. A eficiência de transfecção foi avaliada por fluorescência do repórter vex-GFP e fotografada em microscopia de fluorescência.

Figura 13 - Mapa dos vetores auxiliares necessários para a produção lentiviral

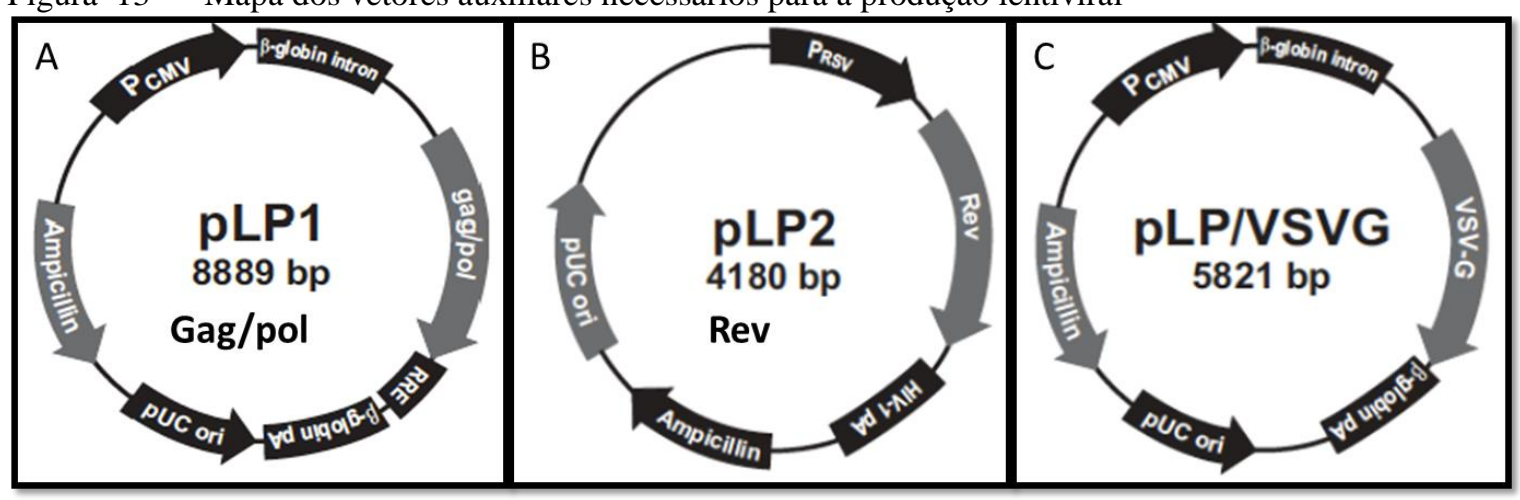

Fonte: Imagem adaptada Virapower Lentiviral Kit (Life Technologies)

Legenda: Mapa dos vetores auxiliares necessários para a produção lentiviral. A) pLP1 que contem as sequências gag/pol, B) pLP2 contendo a sequência Rev, C) e o vetor contendo a proteína de envelope pLP/VSVG. 


\subsubsection{Citometria de Fluxo - Cell sorting}

A porcentagem de células expressando os repórteres fluorescentes foi analisada por citometria de fluxo (FACSAria, BD Biosciences) e as células positivas passaram por sorting e foram mantidas em cultivo e criopreservadas para estudos futuros. Para o protocolo de purificação celular (cell sorting), as células 293FT transfectadas com os vetores OCT4 e SOX2 foram tripsinizadas, centrifugadas e ressuspendidas em $1 \mathrm{~mL}$ de meio IMDM, tal população foi então submetida a purificação celular que, resumidamente, se inicia visando que as células marcadas sejam direcionadas para um recipiente que as armazene. Cada célula dentro de uma gota é interceptada pelo laser e posteriormente passa por uma placa de carreamento de elétrons, onde recebe uma carga positiva ou negativa dependendo do critério de seleção pré-estabelecido no software de aquisição e análise. A seguir, as gotas são atraídas por placas defletoras com carga elétrica contrária à da gota, de forma que as gotas carregadas ao invés de seguirem o fluxo de líquido contínuo, são atraídas pelas respectivas placas, separando-as em positivas e negativas. Apenas as células positivas são recuperadas, centrifugadas, plaqueadas (para posterior avaliação em microscopia confocal) ou lavadas em solução PBS e congeladas (para análises de PCR).

\subsubsection{Reação de Polimerase em cadeia}

O RNA total (a partir de amostras purificadas) foi isolado pelo método do reagente Trizol (Life Technologies). A quantificação dos ácidos ribonucleicos foi realizada usando o espectrofotômetro Nanodrop. Para a síntese de cDNA foi utilizado kit cDNA Transcrição Reversa de Alta Capacidade (Applied Biosystems), este kit utiliza iniciadores aleatórios para a conversão de RNA total em cDNA.

A quantificação do cDNA foi realizada utilizando a metodologia de PCR quantitativo (Step One Real Time PCR Systems, Life Technologies). As reações foram realizadas usando um ensaio comercial (SYBR®Green PCR Master Mix, Life Technologies). Os genes alvo avaliados foram OCT4 e SOX2 devido a sua grande importância na reprogramação e pluripotência. Como referência endógena, foi utilizado o gene gliceraldeído 3-fosfato desidrogenase (GAPDH). As sequências dos iniciadores estão descritas no quadro 1 e os resultados foram avaliados pelo método $2^{\text {DDCt }}$ (LIVAK; SCHMITTGEN, 2001). 
Quadro 2 - Sequências dos primers usados para qPCR, de acordo com Bressan, 2013

\begin{tabular}{|c|c|}
\hline Gene & Sequência (5'- 3') \\
\hline OCT4_FWD & CAGGCCCGAAAGAGAAAGC \\
\hline OCT4_REV & CGGGCACTGCAGGAACA \\
\hline SOX2_FWD & TGCGAGCGCTGCACAT \\
\hline SOX2_REV & TCATGAGCGTCTTGGTTTTCC \\
\hline GAPDH_FWD & AAGGCCATCACCATCTTCCA \\
\hline GAPDH_REV & CCACTACATACTCAGCACCAGCAT \\
\hline
\end{tabular}

\subsubsection{Microscopia confocal}

As células purificadas por Cell Sorting foram plaqueadas em IMDM na concentração de $5 \times 10^{5}$ em poços de cultivo adaptados com lamínula no fundo, para que as células se aderissem nesta superfície, podendo ser levadas ao confocal ainda vivas para detecção da fluorescência.

O sistema conhecido como microscopia confocal utiliza uma fonte de laser para promover a excitação dos fluoróforos. As células viáveis foram submetidas à este sistema equipado com um filtro de espectro de fluorescência (Leica SP5 TSC AOBS, Leica Microsystems). As células transfectadas com OCT4-vexGFP foram analisadas com laser de excitação a $405 \mathrm{~nm}$ e emissão a 535nm e as transfectadas com SOX2-mCitrine, analisadas com laser de excitação 529nm e emissão a 514nm. As imagens foram analisadas pelo software LAS-AF com módulos Live Data, FRAP, FRET AB e SE. 


\subsection{Resultados}

Todos os plasmídeos foram testados quanto a sua funcionalidades, em transfecções com o reagente lipofectamina. O sucesso de tal procedimento era confirmado com a taxa de expressão do repórter fluorescente, por microscopia, as células 293FT utilizadas para produção lentiviral, mostraram grande eficácia na produção viral (Figura 14A) que é finalizada com o rompimento da célula e extrusão das partículas lentivirais no meio de cultivo. A alta taxa de transfecção pode ser confirmada pela fluorescência de GFP (Figura 14B).

Figura 14 - Células 293FT fotografadas após 48h de transfecção, mostrando a produção viral
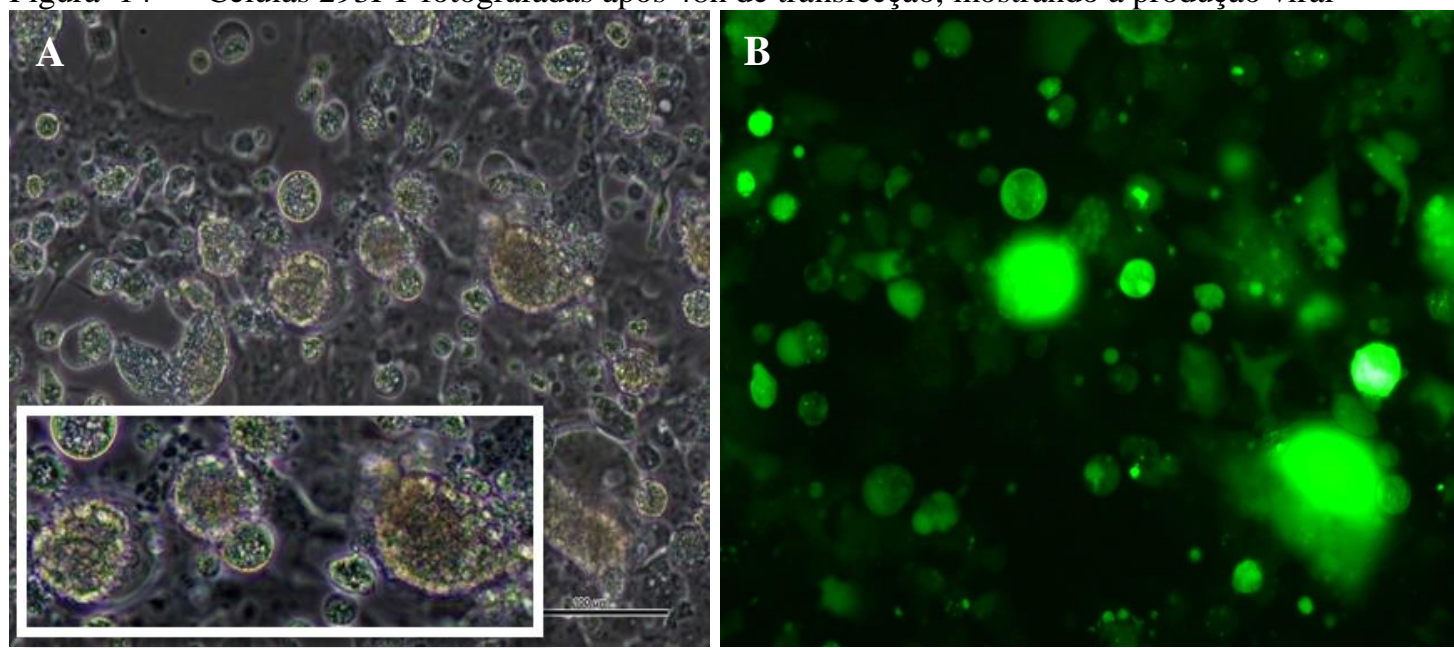

Fonte: (GONÇALVES, N. N., 2015).

Legenda: A) Células 293FT fotografadas após 48h de transfecção, mostrando a replicação viral, observar no aumento abaixo da figura A células 293FT repletas de cópias virais. B) Células 293FT transfectadas com a proteína fluorescente $O C T 4$-vexGFP, confirmando a alta taxa de transfecção.

Para o cell sorting, o citômetro tem um sistema específico que permite a separação de populações celulares puras e homogêneas, a partir de uma amostra heterogênea, de acordo com critérios biológicos predefinidos, neste caso, as células OCT4-vexGFP, SOX2-mCitrine em diferentes concentrações e a combinação de ambos, tiveram suas populações positivas separadas daquelas não transduzidas, onde todas se mostraram altamente positivas. (Figuras 15 e 16). A concentração do fator não foi um ponto determinante para o aumento ou diminuição da sua expressão, uma vez que todos os gráficos evidenciaram altos níveis de integração dos vetores às células. A porcentagem de células positivas pode ser usada como parâmetro da eficiência de transdução. 
Figura 15 - Análise fluxo-citométrica de populações combinadas e separadas OCT4 e SOX2, separadas por sorting

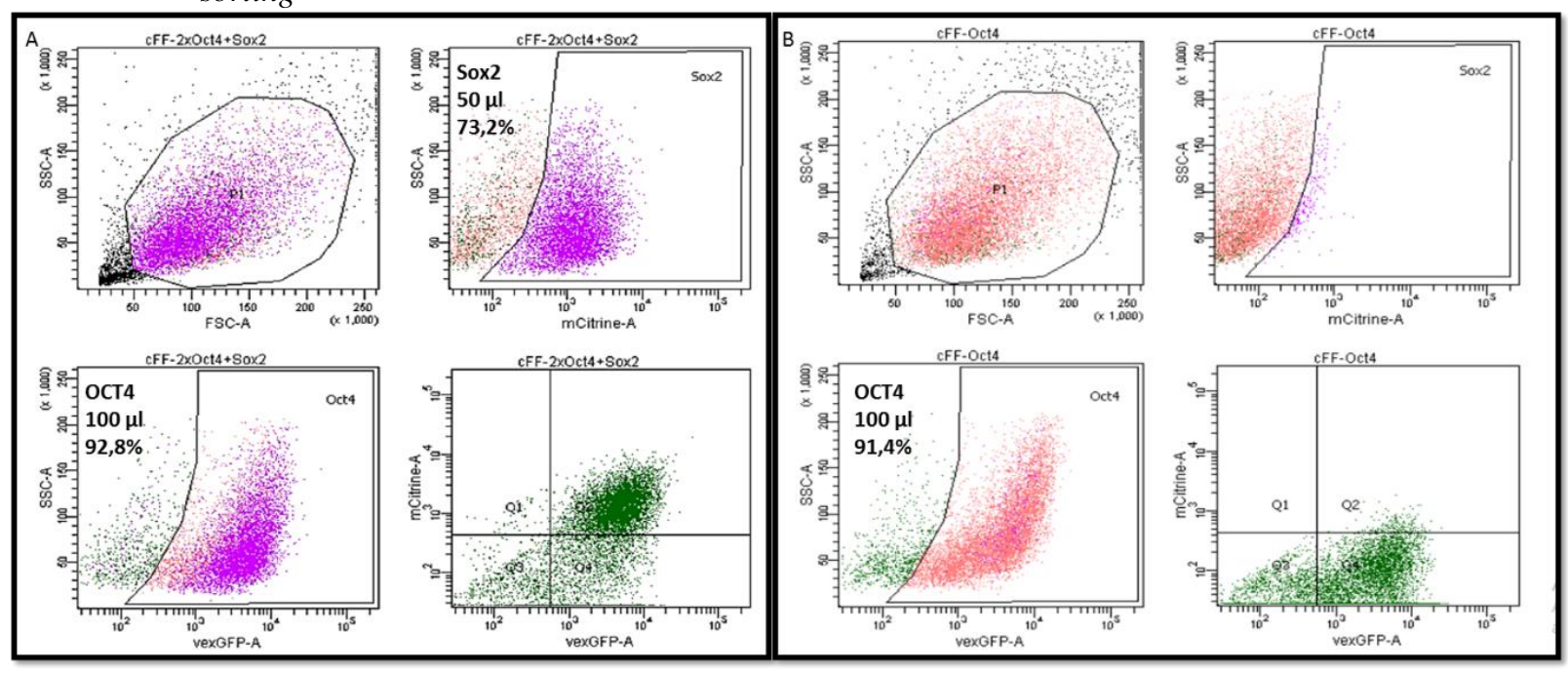

Fonte: (GONÇALVES, N. N., 2015).

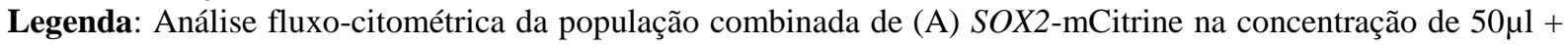
OCT4-vexGFP $100 \mu \mathrm{l}$, positivas, e (B) população única de OCT4 na concentração de $100 \mu \mathrm{l}$, separadas por citometria de fluxo em fibroblastos caninos transgênicos.

Figura 16 - Análise fluxo-citométrica da população única de SOX2-mCitrine separadas por sorting
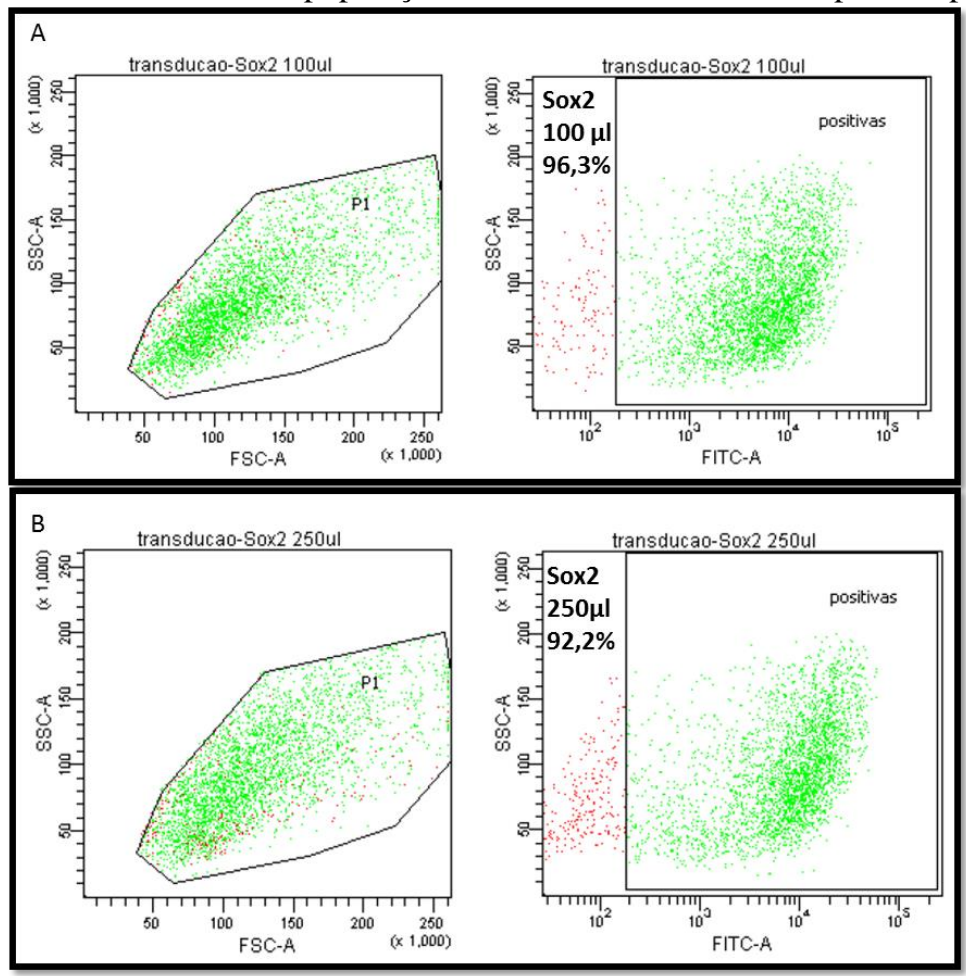

Fonte: (GONÇALVES, N. N., 2015).

Legenda: Análise fluxo-citométrica da população única de (A) SOX2-mCitrine na concentração de $100 \mu 1$ e (B) população única $S O X 2$-mCitrine na concentração de $250 \mu 1$, separadas por citometria de fluxo em fibroblastos caninos transgênicos. 
O sistema da microscopia confocal utiliza uma fonte de laser para promover a excitação dos fluoróforos criando imagens sucessivas de diferentes planos da mesma amostra, possibilitando a construção de imagens tridimensionais precisas expressando a positividade do repórter associado. Os fibroblastos que receberam os vetores associados a proteínas repórteres, de fato, estavam integrados as células, fato evidenciado por alta fluorescência detectada (Figura 17).

Figura 17 - Microscopia confocal para fibroblastos caninos fetais expressando as proteínas repórteres fluorescentes
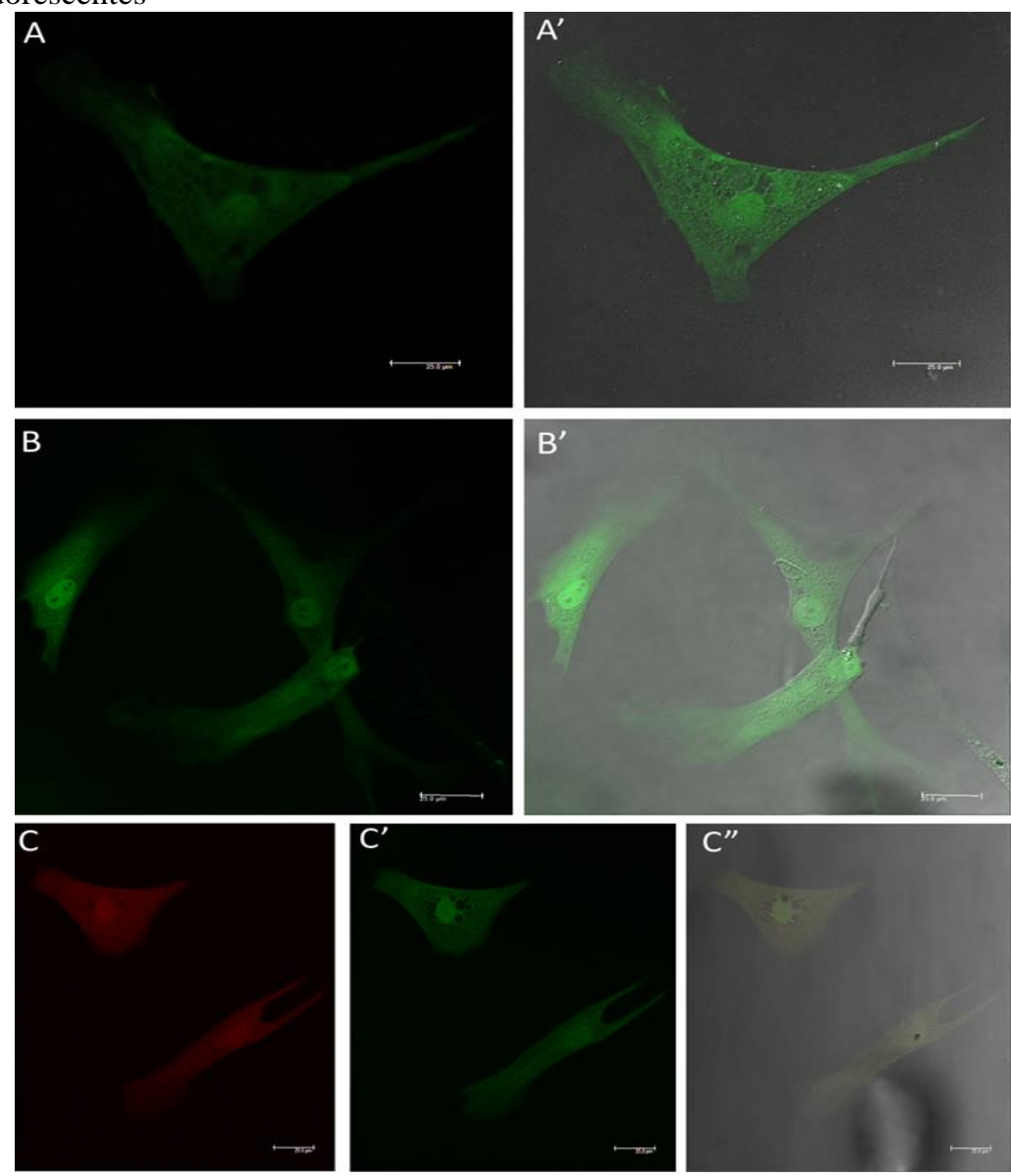

Fonte: (GONÇALVES, N. N., 2015).

Legenda: Microscopia confocal para fibroblastos caninos fetais expressando as proteínas repórteres fluorescentes. A e A': OCT4-vexGFP e imagem mesclada. B e B': SOX2-mCitrine e imagem mesclada. C, C' e C": OCT4-vexGFP, SOX2-mCitrine e duplo positivo, respectivamente.

Fibroblastos fetais caninos expressando OCT4 e SOX2 foram avaliados por PCR tempo real, comparados a fibroblastos não transduzidos. A expressão de OCT4 foi maior (Figura 18A) do que a de SOX2 (Figura 18B) apesar de ambos serem expressos, as associações $O C T 4+S O X 2$ e 2x $O C T 4+S O X 2$ aumentaram a expressão de $S O X 2$ quando 
comparados aos fibroblastos transduzidos apenas com SOX2, porém para OCT4 a associação dos fatores inibiu sua expressão. De forma geral, verifica-se alta expressão em todos os casos.

Figura 18 - Gráfico representando a expressão de hSOX2 e hOCT4, e a combinação dos fatores

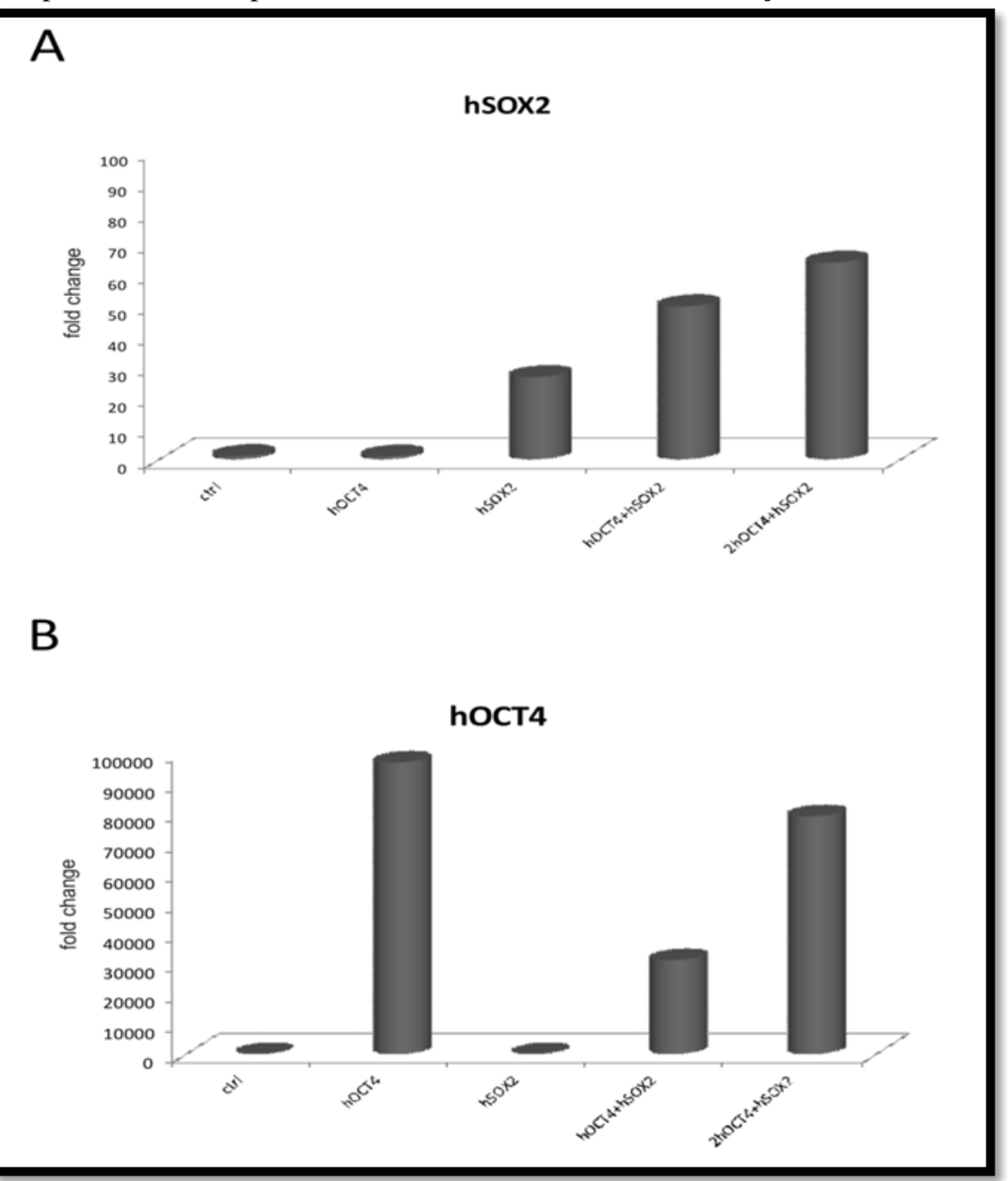

Fonte: (GONÇALVES, N. N., 2015).

Legenda: Gráfico representando a expressão de hSOX2 (A) e hOCT4 (B) em separado e em associação, bem 2x hOCT4 + hSOX2 nas linhagens IPS canina, comparadas a fibroblastos fetais não reprogramados, em unidades arbitrárias. 


\subsection{Discussão}

Descrevemos linhagens de fibroblastos fetais caninos expressando diferentes fatores de transcrição humanos relacionados à pluripotência. Estas linhagens celulares são importantes para o desenvolvimento de células-tronco pluripotentes induzidas completamente reprogramadas, derivadas deste modelo animal.

A quantidade de células em que os fatores de reprogramação se integraram no genoma canino foi determinada através da expressão do gene repórter fluorescente detectada por sorting em citometria de fluxo. Assim, pudemos observar que as células caninas se mostraram sensíveis à integração e expressão do OCT4 e SOX2 humano em uma eficiência elevada, raramente observado em outras espécies (HUANGFU et al., 2008).

A análise por microscopia de fluorescência revelou que a distribuição de proteínas repórter é semelhante entre as duas diferentes construções proteicas e que não se restringe a uma região da célula em particular.

OCT4 e SOX2 mostraram uma elevada expressão exógena de cada gene alvo, bem como células dupla positivas. No entanto, nenhuma interação (formação de colônia) foi observada pelo menos 6 dias após a transdução. De acordo com Hammachi et al. (2012) OCT4 é um regulador essencial da pluripotência, assim como um mediador chave da reprogramação das células somáticas induzidas e a sua interação com $S O X 2$ pode ser essencial para esse processo (RIZZINO, 2009).

A separação de populações positivas, como foi demonstrado neste experimento, permite que apenas as células que incorporaram os fatores sejam cultivadas, aumentando, em teoria, a eficiência de reprogramação. 
Capítulo 8: Produção e caracterização das células pluripotentes induzidas no modelo canino 


\section{PRODUÇÃo E CARACTERIZAÇÃo DAS CÉLULAS PLURIPOTENTES INDUZIDAS NO MODELO CANINO}

Neste capítulo descrevemos o mecanismo de reprogramação por integração lentiviral para indução da pluripotência em fibroblastos fetais de cão. A obtenção de CTE-like na espécie canina é de grande importância para a ciência, uma vez que os cães são forte modelo de estudo por sua homologia em diversas doenças genéticas. Além disso, as dificuldades de se acessar e caracterizar células-tronco embrionárias verdadeiras nas espécies domésticas ainda é um problema, com resultados pouco conclusivos; o estudo de tais linhagens induzidas pode aprofundar o conhecimento do perfil epigenético de tais células. As linhagens obtidas e completamente caracterizadas neste estudo não seguem os protocolos já descritos na literatura, com importantes alterações, como a independência de LIF ou qualquer outra suplementação com inibidores, sendo dependente apenas de bFGF; destacando ainda o uso de vetores policistrônicos, bem como sua resistência ao repique enzimático. O processo de reprogramação delineado neste experimento apresentou índices máximo de $0.001 \%$ de eficiência.

O entendimento e caracterização de tais linhagens em cães possibilitará seu uso em diversas vertentes terapêuticas bem como o estabelecimento de um importante modelo de estudo pré-clínico de terapias celulares e gênicas. Além de possibilitar novos protocolos e otimizações do processo com o objetivo de tornar tais linhagens cada vez mais reprodutíveis e seguras.

Estes resultados foram divulgados na Revista eletrônica FAPESP e apresentados no International Federation of Placenta Associations - IFPA 2014 (Anexo D 1 e 2)

1) GONÇALVES, N. J. N.; AMBRÓSIO, C. E. Parceria busca linhagem segura de células tronco para tratar lesão medular. REVISTA FAPESP (online) 2013. Home page: http://agencia.fapesp.br/18298

2) GONCALVES, N.; BRESSAN, F.; MEIRELLES, F.; AMBRÓSIO, C. Reprogramming by Gene Induction: The Factors Involved in the establishment of Canine Stem Cells. Placenta. $\quad$ v. $\quad 35, \quad$ n. $\quad 9, \quad$ p. $\quad$ A92, 2014. DOI: http://dx.doi.org/10.1016/j.placenta.2014.06.299 


\subsection{Material e Métodos}

\subsubsection{Produção de fibroblasto fetal canino}

Fibroblastos fetais caninos foram derivados de um embrião com aproximadamente 15 dias de idade gestacional (Figura 19) (idade determinada por medidas de crown-rump, embrião com medida de $0.9 \mathrm{~cm}$ ). Somente os somitos foram preservados e em seguida lavados com solução salina PBS, foram fragmentados e desagregados por pipetagem e as células em suspensão foram cultivadas em meio de cultivo completo IMDM (Gibco) suplementado com $10 \%$ de soro fetal bovino e antibióticos (Gibco).

Figura 19 - Embrião canino com aproximadamente 15 dias de idade gestacional, utilizado para o cultivo de fibroblastos

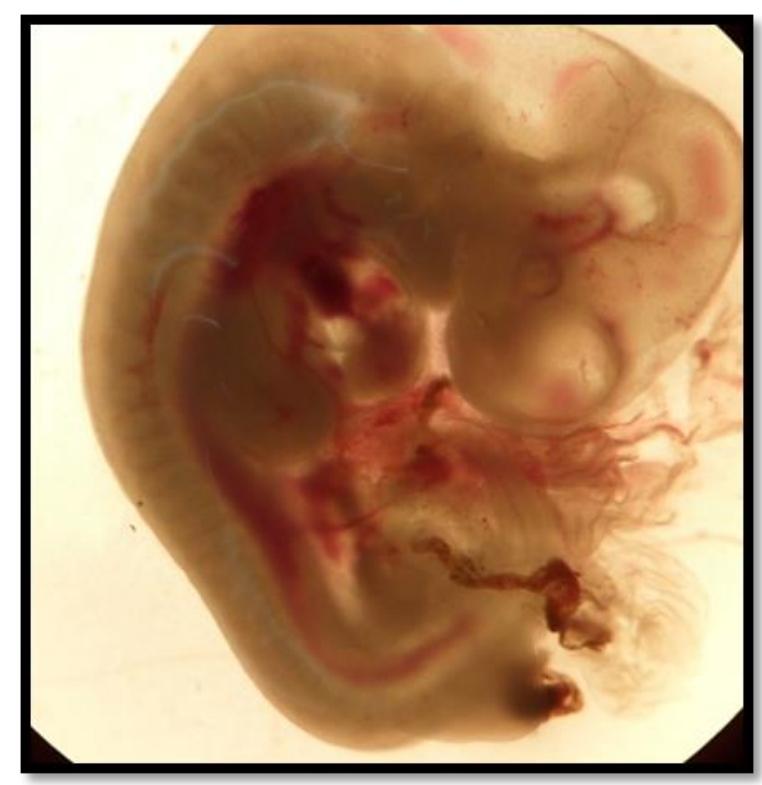

Fonte: (GONÇALVES, N. N., 2015).

Legenda: Embrião canino com aproximadamente 15 dias de idade gestacional, utilizado para o cultivo de fibroblastos. Foram removidos órgãos, cabeça e membros e apenas os somitos foram preservados. Fotografado em lupa de aumento.

\subsubsection{Produção de fibroblastos embrionários murinos para monocamada de cultivo}

Camundongos Swiss (3 fêmeas e 1 macho) foram colocados para acasalar e a cópula foi confirmada em 1 fêmea pela presença de tampão vaginal. A fêmea foi separada das demais e após 13,5 dias foi sacrificada em câmara de $\mathrm{CO}_{2}$, com confirmação por deslocamento 
cervical. O útero gravídico foi retirado e armazenado imediatamente em solução salina PBS com antibióticos e antifúngico. Os úteros foram dissecados e para os 13 embriões recuperados (Figura 20), foram removidos os órgãos, cabeça e membros e o restante do tecido foi macerado e incubado com Colagenase IV (Sigma-Aldrich 0,040g/mL) por 3 h a $38,5^{\circ} \mathrm{C}$. Após a incubação o tecido digerido foi lavado e plaqueado em meio de cultivo completo IMDM. Foram divididos 4 embriões para 1 garrafa de cultivo de $75 \mathrm{~cm}^{2}$, após $48 \mathrm{~h}$ os cultivos foram congelados para posterior utilização.

Para a produção de monocamada (MEFs) os fibroblastos murinos foram inativados com mitomicina C, um inibidor da síntese de DNA (Sigma-Aldrich), onde garrafas de cultivo com aproximadamente $80 \%$ de confluência foram incubados com mitomicina $(10 \mathrm{mg} / \mathrm{mL})$ por 3h em incubadora, após este período os cultivos foram tripsinizados, contados e replaqueados na concentração de $1,2 \times 10^{5}$ células em placas de $35 \mathrm{~mm}$.

Figura 20 - Coleta de embriões murinos com 13,5 dias de idade gestacional

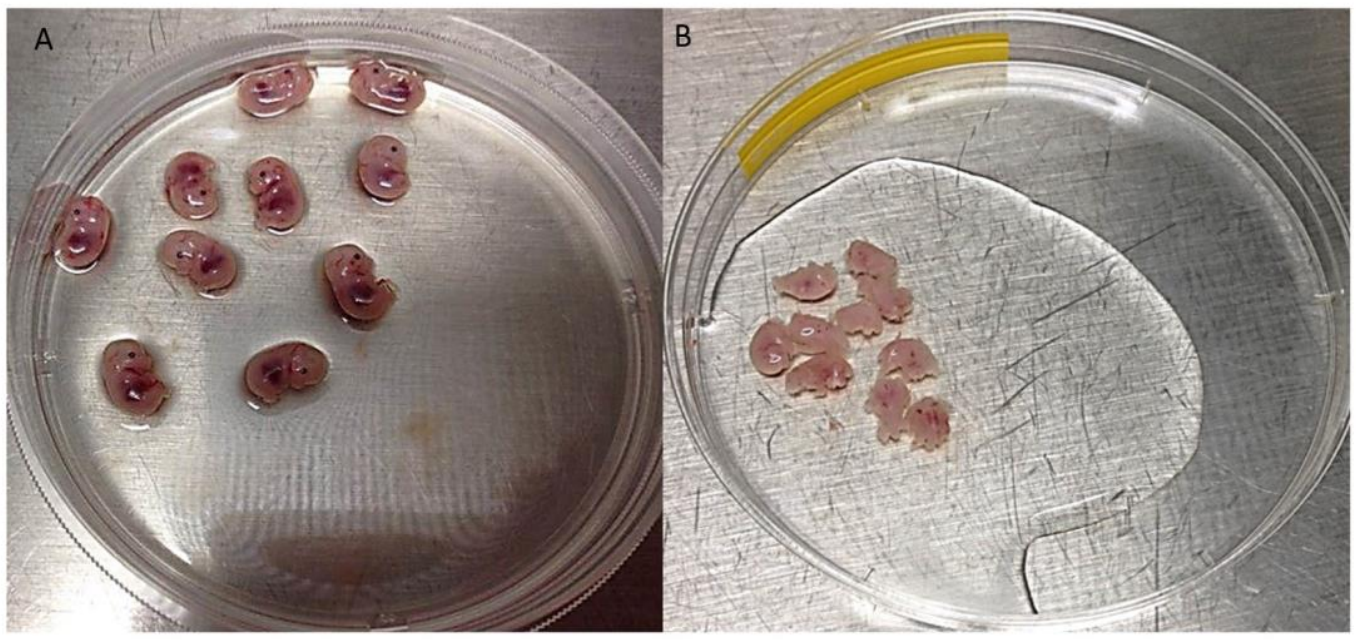

Fonte: (GONÇALVES, N. N., 2015).

Legenda: Coleta de embriões murinos com 13,5 dias de idade gestacional. Em A, embriões recuperados do útero e lavados com PBS. Em B, embriões com órgãos, cabeça e membros removidos. 


\subsubsection{Vetores Virais}

Foram utilizados vetores lentivirais policistrônicos STEMCCA (SOMMER et al., 2009) construído como um sistema de múltipla expressão das proteínas OCT4, SOX2, KLF4, e $c$-MYC (Figura 21) humanas (hOSKM) ou murinas (mOSKM), para uma transfecção eficiente foram usados plasmídeos auxiliares contendo as sequências de TAT, REV, Hgpm2 e o empacotador VSGV. O plasmídeo policistrônico foi provido em stab bacteriano, passando pelo mesmo procedimento descrito na preparação de plasmídeos do experimento 1, sendo preparados por MaxiPrep e quantificados em Nanodrop.

Figura 21 - Esquema representando construção do vetor policistrônico STEMCCA

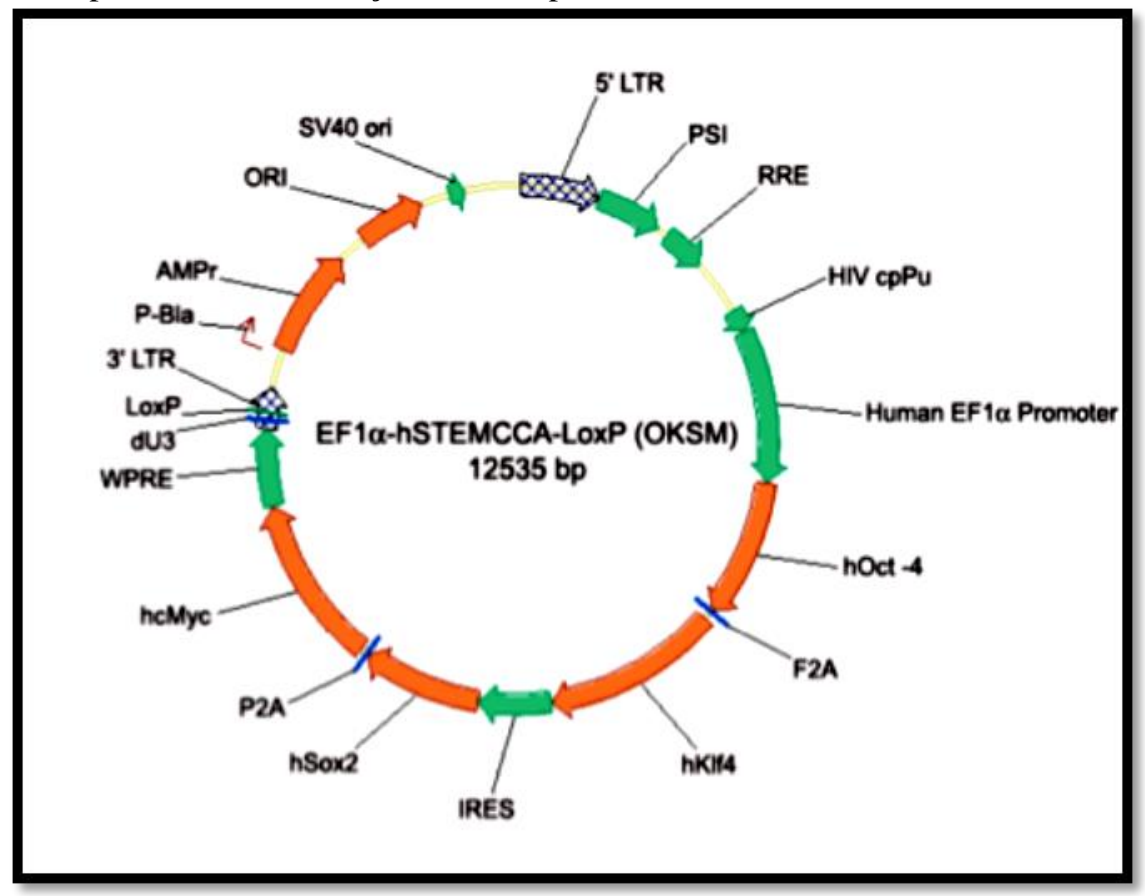

Fonte: Millipore Humano catálogo SCR544 e Mouse catálogo SCR518

Legenda: Esquema representando construção do vetor policistrônico. Imagem obtida do catálogo Millipore referenciando a construção STEMCCA humana (hOSKM), sendo que a construção para o vetor mouse (mOSKM) segue a mesma representação.

\subsubsection{Produção das partículas lentivirais}

Para a produção viral, $5 \times 10^{6}$ células 293FT foram plaqueadas no dia anterior, em placas de 100mm para que no momento da transfecção estivessem $90 \%$ confluentes, as células 
293FT foram transfectadas com $12 \mu \mathrm{g}$ do vetor hOSKM e/ou mOSKM e $1.2 \mu \mathrm{g}$ de cada auxiliar e $2.4 \mu \mathrm{g}$ do auxiliar VSVG, utilizando o reagente lipofectamina 2000 (Life Technologies). A lipofecção foi incubada por 12 horas [overnight] e o sobrenadante (meio de cultivo) foi recuperado após 24 e $48 \mathrm{~h}$, filtrado e as partículas virais foram mantidas a $4^{\circ} \mathrm{C} \mathrm{e}$ utilizadas no mesmo dia. Foram produzidas partículas de hOSKM e também mOSKM, para a transdução combinada e em separado, para que pudessemos observar qual a melhor combinação para a reprogramação das células caninas.

\subsubsection{Transdução celular}

O cultivo celular foi previamente plaqueado (fibroblastos fetais caninos) na concentração de $1.5 \times 10^{4}$ por poço (placas de 6 poços) cada poço recebeu $1 \mathrm{~mL}$ da produção viral, estes foram incubados por 12-16 horas (overnight) e o meio de cultivo foi trocado. Este procedimento foi repetido no dia seguinte, totalizando duas infecções virais, sendo considerado D0 o primeiro dia da infecção. Após 5 dias, as células transduzidas foram transferidas para MEFs previamente mitomicinizadas, por um mínimo de 14 dias. Durante este período de reprogramação celular, as células receberam meio de cultura adequado, nomeado pelo nosso grupo de trabalho, como meio IPS, que é composto por: DMEM/F12 Knockout (Life Technologies /Gibco) suplementado com 20\% de substituto de soro (KSR Knochout serum replacement, Life Technologies) 1\% L-glutamina (Life Technologies), 1:1000 B-mercaptoetanol (Life Technologies), 1\% de aminoácidos não essenciais (Life Technologies) 10 $\mathrm{\mu g} / \mathrm{mL}$ bFGF (Peprotech) e antibióticos (penicilina/streptomicina - SigmaAldrich) além de um deliniamento experimental (Fig. 9) que consiste em testar células transduzidas com a adição de Fator inibidor de Leucemia humano (Human Leukemia Inhibitory Factor - LIF 1000U/mL, Millipore), ou iGSK3 (inibidor da via de sinalização da glicogênio sintase quinase 3,3 $\mu \mathrm{M}$, Stemgent) e iMEK (inibidor da via de sinalização da proteína quinase ativa por mitógeno quinase/ $1 \mu \mathrm{M}$ ) ou ainda os dois inibidores (2i) acrescidos de LIF (Figura 22). Todo o processo de reprogramação segue uma sequência temporal de eventos importantes para o estabelecimento de colônias e sua manutenção, tais etapas fazem parte de cada novo processo de reprogramação exemplificando que desde a transdução (Do) até a obtenção de linhagens clonais iniciais, foi necessário, ao menos, 30 dias (Figura 23). 
Figura 22 - Plano experimental das células transduzidas - experimento 3

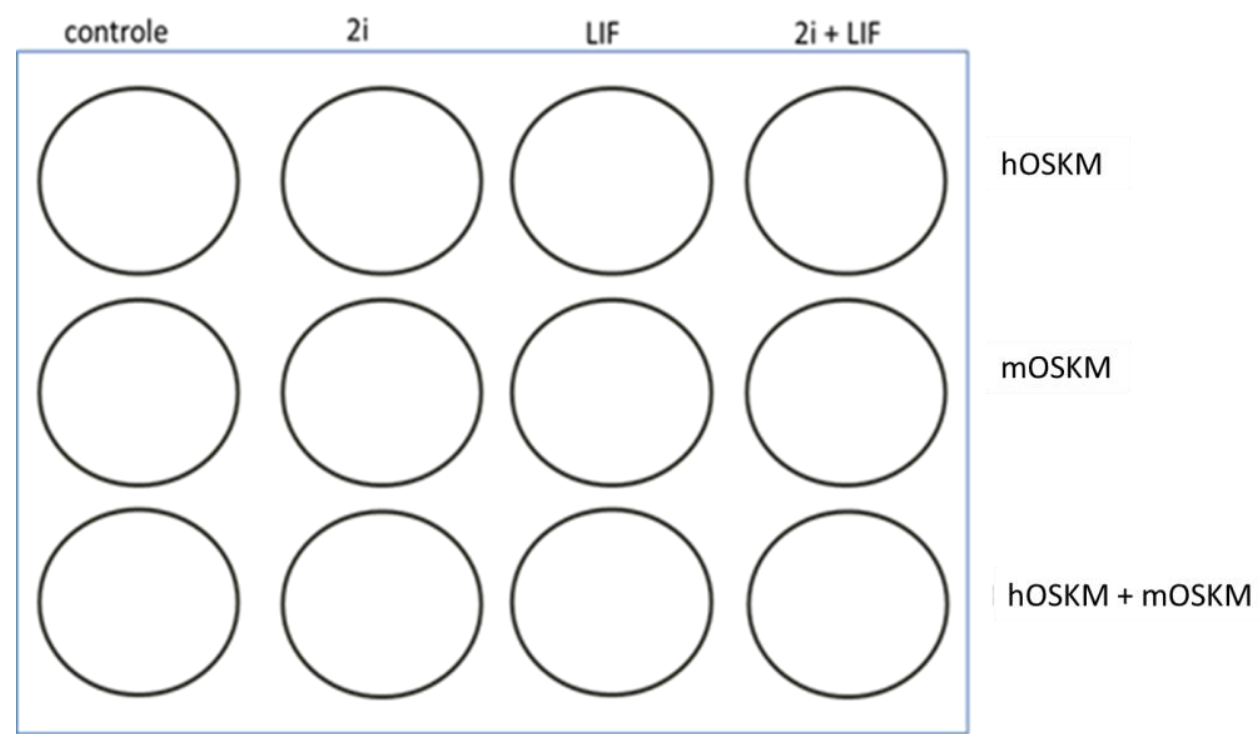

Fonte: (GONÇALVES, N. N., 2015).

Legenda: Plano experimental das células transduzidas com fator humano (hOSKM), murino (mOSKM) ou a combinação (hOSKM + mOSKM) cultivadas em placas de 6 poços com MEFs na presença de $2 \mathrm{i}$ (inibidores), LIF, 2i + LIF, comparadas às células transduzidas controle (sem suplementação).

Figura 23 - Esquema temporal do processo de reprogramação

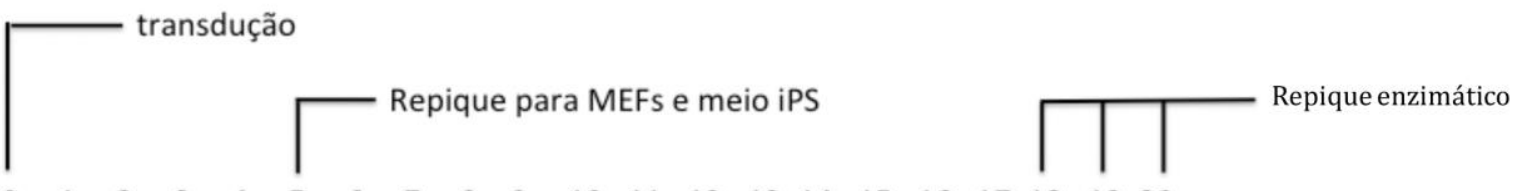

$\begin{array}{llllllllllllllllllllll}0 & 1 & 2 & 3 & 4 & 5 & 6 & 7 & 8 & 9 & 10 & 11 & 12 & 13 & 14 & 15 & 16 & 17 & 18 & 19 & 20 & \ldots\end{array}$

\begin{tabular}{|c|c|}
\hline Meio IMDM & Meio iPS + MEFs \\
\hline
\end{tabular}

Fonte: (GONÇALVES, N. N., 2015).

Legenda: Esquema temporal do processo de reprogramação, e as etapas necessárias para o estabelecimento e manutenção de uma linhagem iPS. Considerando uma escala de tempo em dias, o processo requer ao menos 1 mês para obtenção de linhagens clonais.

\subsubsection{Detecção da expressão enzimática de fosfatase alcalina}

O teste para detecção da fosfatase alcalina nas linhagens de IPS canina foi feito com o kit Leukocyte Alkaline Phosphatase (Sigma-Aldrich) de acordo com instruções do fabricante. Depósitos insolúveis de corante vermelho indicam a atividade da fosfatase alcalina, e altos níveis de expressão da fosfatase caracterizam células indiferenciadas pluripotentes. 


\subsubsection{Formação de corpos embrióides e diferenciação in vitro}

Placas de cultivo de $35 \mathrm{~mm}$ foram tratadas com agarose $0,6 \%$ autoclavada, após cerca de 20 min com a camada solidificada, células IPS caninas foram repicadas normalmente e cultivas sobre a agarose em meio de cultivo sem adição de bFGF por 48 - 72 horas. Após a formação dos corpos embrióides, estes foram recuperados e plaqueados sob camada de gelatina $0,1 \%$ para a indução da diferenciação in vitro. Foram então mantidos em cultivo por um mínimo de 6 dias com uso de meio de cultivo adequado à diferenciação (IMDM suplementado com 10\% SFB e antibióticos).

\subsubsection{Análise da expressão gênica de fatores relacionados à pluripotência}

As células caninas pós reprogramação in vitro foram submetidas à avaliação da expressão dos genes relacionados à pluripotência: OCT4, SOX2 e o controle endógeno $18 S$. Para tal análise, as colônias foram plaqueadas em Matrigel $(10 \mu 1 / \mathrm{mL}), 24 / 48 \mathrm{~h}$ antes de serem tripsinizadas e coletadas. O cultivo foi tripsinizado e lavado com PBS simples filtrado, as células precipitadas foram congeladas em $-80{ }^{\circ} \mathrm{C}$ até o momento da extração. O RNA foi isolado pelo método Trizol (Trizol Reagente, Life Technologies) em um protocolo adaptado com acrilamida linear $(5 \mathrm{mg} / \mathrm{mL}$, Ambion) para melhor visualização do precipitado. Após o isolamento do RNA, sua quantificação foi feita em espectrofotômetro Nanodrop. A conversão do RNA em cDNA foi feita com o kit High Capacity cDNA Transcrição Reversa (Apllied Biosystems) com auxílio de primers randômicos para a síntese de cDNA a partir do RNA isolado. A expressão do cDNA foi quantificada por PCR tempo real como o equipamento Step One Real Time (PCR Systems, Life Technologies). As reações foram realizadas usando um ensaio comercial (SYBR®Green PCR Master Mix, Life Technologies). Os primers foram previamente desenhados (Quadro 2) e foram diluídos para a concentração final de $100 \mathrm{nMol}$ em condições padrão de termociclagem (anelamento $60^{\circ} \mathrm{C}$ por 40 ciclos). A eficiência e quantificação das amostras, em duplicatas, foram avaliadas com o método $2^{-\triangle \Delta C T}$ (LIVAK; SCHMITTGEN, 2001). 
Quadro 3 - Sequências dos primers utilizados para análise da pluripotência, de acordo com Bressan - 2013

\begin{tabular}{|l|l|}
\hline Gene & Sequência (5'-3') \\
\hline OCT4_FWD & CAGGCCCGAAAGAGAAAGC \\
\hline OCT4_REV & CGGGCACTGCAGGAACA \\
\hline SOX2_REV & TGCGAGCGCTGCACAT \\
\hline 18S_FWD & TCATGAGCGTCTTGGTTTTCC \\
\hline 18S_REV & CCTGCGGCTTAATTTGACTC \\
\hline
\end{tabular}

\subsubsection{Detecção da proteína $O C T 4, S O X 2$ e $N A N O G$ por imunofluorescência}

O protocolo utilizado foi descrito por Oliveira et al. (2012), onde linhagens clonais de iPS canina foram plaqueadas em NUNC com MEF, fixadas em paraformaldeído $4 \%$ por 20 min e mantidas overnight a $4^{\circ} \mathrm{C}$ com uma solução de PBS suplementado com BSA $3 \%$ e Triton X-100 0.5\%, no dia seguinte, os cultivos foram incubados em solução de bloqueio (PBS com BSA 3\% e Tween-20 0,2\% ) por 1 hora em temperatura ambiente. Após o bloqueio, as linhagens foram incubadas com o anticorpo primário específico para OCT3/4 anti-rabbit, diluído 1:50 (Sigma-Aldrich C279); SOX2 anti-rabbit IgG, diluído 1:100 (Abcam ab97959), e NANOG anti-rabbit IgG, duluído 1:100 (Abcam ab80892) overnight a $4^{\circ} \mathrm{C}$. Foram entao lavados três vezes com PBS e receberam o anticorpo secundário (goat anti- rabbit Ig-G 488 Alexa Fluor, A-11008, Life Technologies) na diluição de 1:100 por 2 hs. Foram então lavados com PBS e avaliados em microscopia de fluorescência (Zeiss, AXIVISION 4.7.1. Carl Zeiss). 


\subsubsection{Caracterização in vivo - formação de teratoma em camundongos imunosuprimidos Balb c/nude}

Para a formação de teratoma, as linhagens IPS caninas $4 \mathrm{~h}+\mathrm{m}$ e $12 \mathrm{~h}$ foram injetadas, em ambiente estéril, via subcutânea em camundungos fêmeas jovens, balb/c NUDE. Foram injetadas $1.5 \times 10^{6}$ células ressuspendidas em PBS com 30\% de matrigel (BD Biosciences). Os animais foram observados a cada 2 ou 3 dias e mantidos por um período de 150 dias. Após 120 dias foi observada a formação macroscópica de uma massa tumoral, no animal que recebeu a linhagem $4 \mathrm{~h}+\mathrm{m}$, esta foi observada por mais 4 semanas e entao os nudes foram eutanasiados em câmaras de $\mathrm{CO}^{2}$ com confirmação por deslocamento cervical (aprovado em comitê de bioética) e a massa tumoral, bem como os orgãos, foram coletados e analisados histopatologicamente para a comprovação ou não da presença dos três folhetos embrionários, sendo que todos os orgãos e tecidos também foram avaliados por patologista quanto a presença de quaisquer anomalias celulares.

\subsubsection{Separação de Metafase cromossomal e FISH}

Células iPS foram tratadas com Colcemid (Life Technologies), um desestabilizador de microtubulos, na concentração de $10 \mu \mathrm{L} / \mathrm{mL}$ por $1 \mathrm{~h}$ e lavado com PBS. As células foram tripsinizadas e incubadas por 25 min em solução hipotônica (Cloreto de potássio $75 \mathrm{mM}$ ) e ressuspendidas com solução fixadora (metanol/ácido acético 3:1 vol:vol) seguido de repetidas etapas de centrifugação e decantação. A separação da metáfase cromossomal foi feita gotejando $10 \mu \mathrm{L}$ de suspensão de células em lâminas previamente resfriadas. As lâminas foram deixadas em temperatura ambiente para secagem, por 10 min e mantidas em $-20^{\circ} \mathrm{C}$ até o momento da análise. A análise FISH foi feita usando sondas citogeneticamente validadas por sistema de clonagem em bactérias. Os cromossomos foram contados por coloração DAPI, as imagens foram capturadas usando um microscópio fluorescente (Axioplan II, Zeiss) equipado com filtros apropriados (Chroma) e câmera CCD (KAF1410E, Sensys) ambos SmartCapture software (Digital Scientific). O status do número de cópias de cada cromossomo foi gravada num mínimo de 30 células de cada amostra, e as provas para reorganização estrutural foram avaliadas. A metodologia FISH foi feita a partir de uma parceria com a Universidade da Carolina do Norte (NCSU), Raleigh, EUA. Que visa o estudo de anomalias cromossomais em células de pluripotência induzida. 


\subsection{Resultados}

A transdução viral de sucesso ocorreu sem que este fosse previamente ultracentrifugado, como nos primeiros experimentos, em parceria com o Laboratório de Biotecnologia do Instituto Hemocentro de Ribeirão Preto, é sabido que a manipulação excessiva e o transporte do vírus é um procedimento laborioso, que aumenta as variáveis, reduz a eficiência de infecção e aumenta as chances de insucesso na reprogramação. A tentantiva da transdução sem prévia concentração viral, foi eficaz, como será observado nas imagens das células reprogramadas a partir deste procedimento, essa nova estratégia foi executada com o objetivo de otimizar a transdução viral, gerando um protocolo mais seguro.

Todas as colônias foram repicadas manualmente para a primeira passagem e enzimaticamente para as demais, com uma adaptação do uso de Tryple express em menor volume, por menos tempo, desta forma, este procedimento não foi tóxico às colônias de um modo geral. Por outro lado, o processo de criopreservação com DMSO aparentemente era extremamente tóxico as colônias, que levavam cerca de 15 dias para retornarem a sua morfologia típica em cultivo sob MEF.

Diferentes protocolos foram testados como o objetivo de otimização da reprogramação, delineando diversas vertentes a serem avaliadas, tais como, o vetor Stemmcca humano, murino e a combinação de ambos; a adição de inibidores (2i), LiF e bFGF em separado ou em conjunto, bem como a concentração inicial de fibroblastos fetais caninos. O resultado de cada protocolo está detalhado na tabela 1 . 
Tabela 1 - Delineamento dos 6 protocolos de transdução, com uso ou não de suplementação, combinando ou não os vetores humano e murino, reprogramando fibroblastos fetais caninos em duas concentrações iniciais. De todos os protocolos foram obtidas 66 linhagens clonais, das quais 18 (dos protocolos 4,5 e $6 \mathrm{~h}+\mathrm{m}$ e h) se mantiveram por no máximo 10 passagens e 10 se mantiveram por 15 ou mais passagens, sendo 7 h+mOSKM e 3 hOSKM em eficiência máxima de reprogramação de $0,001 \%$

\begin{tabular}{|c|c|c|c|c|c|c|}
\hline & 1 & 2 & 3 & 4 & 5 & 6 \\
\hline hOSKM & + & + & + & + & + & + \\
\hline mOSKM & - & - & - & + & + & \\
\hline LIF & + & + & - & & - & - \\
\hline $\mathrm{bFGF}$ & + & + & + & + & + & + \\
\hline $2 \mathrm{i}$ & + & - & - & & - & - \\
\hline Concentração celular & $2 \times 10^{4}$ & $2 \times 10^{4}$ & $1,5 \times 10^{4}$ & $1,5 \times 10^{4}$ & $1,5 \times 10^{4}$ & $1,5 \times 10^{4}$ \\
\hline $\mathrm{N}^{\mathrm{o}}$ de colônias & 3 & 7 & 12 & 10 & 20 & 14 \\
\hline Taxa de eficiência $(\%)$ & $0,00015 \%$ & $0,00035 \%$ & $0,0008 \%$ & $0,00066 \%$ & $0,001 \%$ & $0,0009 \%$ \\
\hline Colônias estáveis & - & - & - & $3(4,5,6)$ & $4(7,8,9)$ & $3(10,11,12)$ \\
\hline
\end{tabular}

Fonte: (GONÇALVES, N. N., 2015).

Nos primeiros dias pós transdução (D4 e D7) não foi possível observar diferenças entre a infecção murina ou humana e ainda tratada ou não com LIF (Figura 24 A-I). As células em processo de reprogramação, apresentaram características de células reprogramadas e colônias iniciais 11 dias após a transdução (Figura 25 A-F), e apesar de ser observado a formação de colônias em todas as transduções, a melhor condição de cultivo foi com hOSKM + mOSKM, sem adição de inibidores, considerando sua manutenção a longo prazo, ressaltando que as células que receberam LIF + inibidores não apresentaram formações que se assemelhassem a colônias iPSC e ainda, as que receberam apenas LIF apresentaram colônias, em menor número, sem diferenças morfológicas ou de desenvolvimento, porém eram aparentemente mais frágeis, sugerindo uma reprogramação incompleta e não se mantiveram após algumas passagens. As linhagens avaliadas eram h+mOSKM ou hOSKM, sendo as h+m mais estáveis a todos os procedimentos, bem como de morfologia mais adequada. Para a afirmação de uma dupla infecção faz-se necessário a confirmação da integração de ambos os fatores ao núcleo por PCR tempo real. 
Figura 24 - Fibroblastos caninos em processo de reprogramação com o vetor policistrônico humano, murino e a combinação de ambos

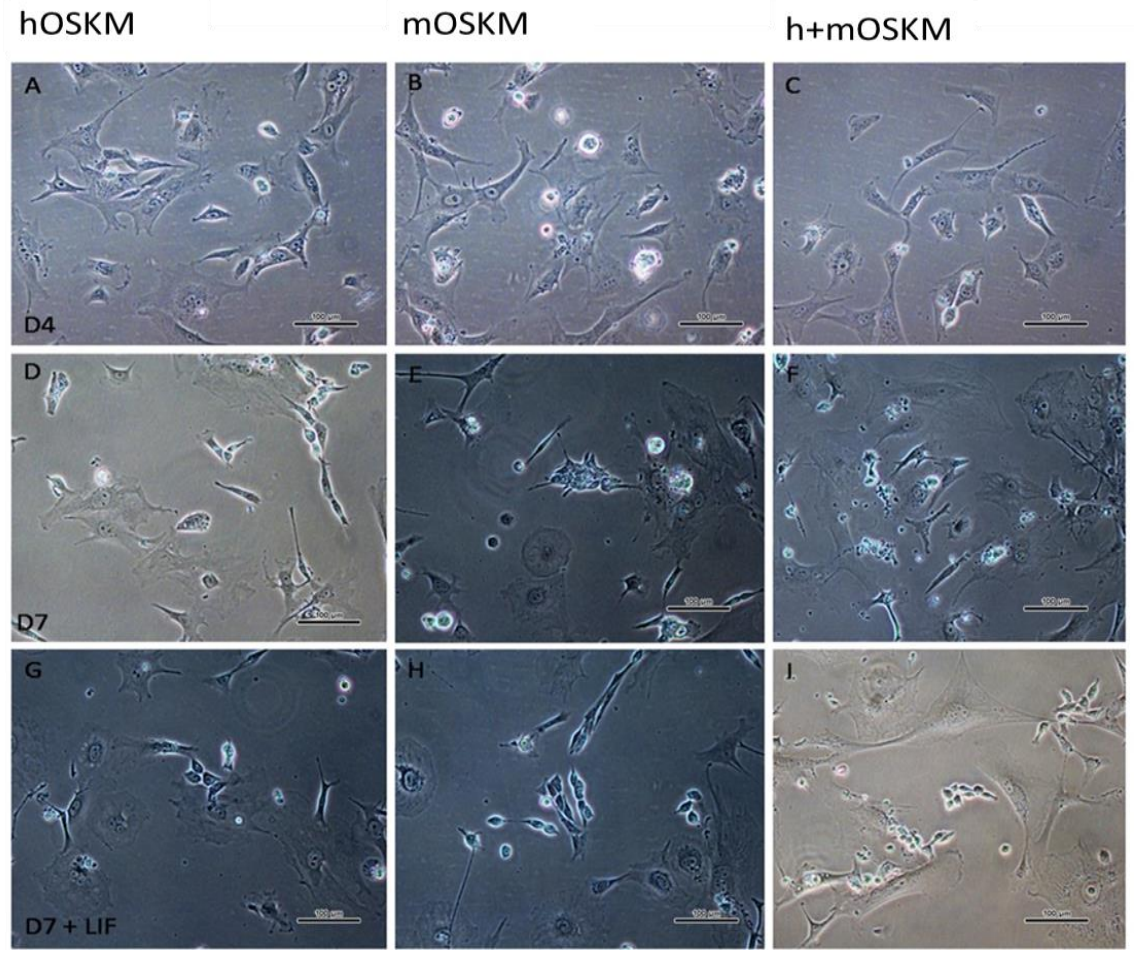

Fonte: (GONÇALVES, N. N., 2015).

Legenda: Fibroblastos caninos em processo de reprogramação com o vetor policistrônico humano (A, D, G), murino (B, E, H) e a combinação de ambos (C, F, I) em D4 (A, B, C), D7 (D, E, F) e D7 acrescido de $\operatorname{LIF}(\mathrm{G}, \mathrm{H}, \mathrm{I})$.

Figura 25 - Fibroblastos caninos em processo de reprogramação com o vetor policistrônico humano, murino e a combinação de ambos em D11

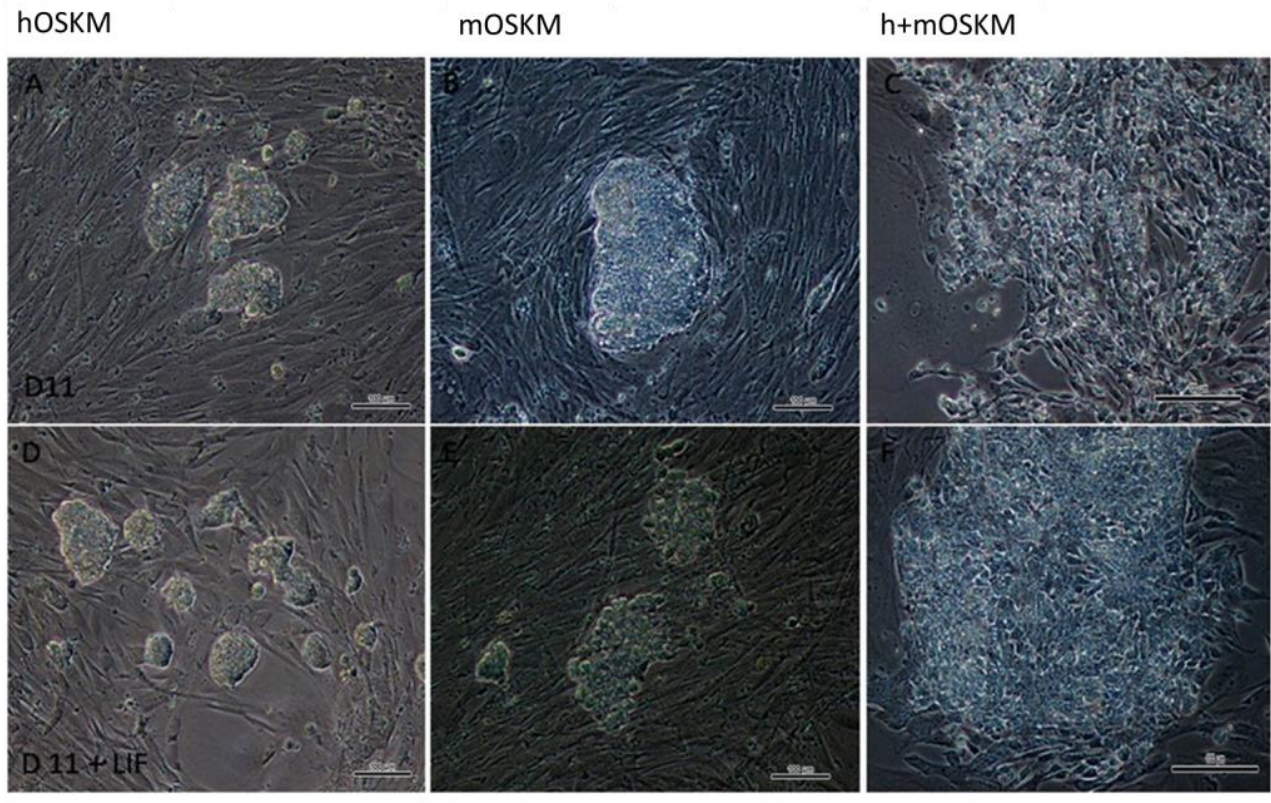

Fonte: (GONÇALVES, N. N., 2015).

Legenda: Fibroblastos caninos em processo de reprogramação com o vetor policistrônico humano (A, D), murino $(\mathrm{B}, \mathrm{E})$ e a combinação de ambos $(\mathrm{C}, \mathrm{F})$ sob diferentes condições de cultivo. Controle (A-C) ou acrescido de LIF (D - F), 11 dias pós transdução. 
Pudemos observar ainda diferenças dependentes do substrato de cultivo, as iPSCs caninas só se estabeleceram e mantiveram uma morfologia adequada, quando mantidas em MEF (Figura 26 B-D). Tais linhagens, quando mantidas em matriz extracelular (Matrigel hESqualified, BD Biociences), tinham sua morfologia típica alterada (Figura 26 A-C), tal substrato já otimizado para o cultivo de iPSC humana (YAMANAKA et al., 2007) e bovina (BRESSAN, 2013) não se mostrou eficaz para as iPSC caninas, apesar de seu uso para tal espécie já ter sido relatado (LUO et al., 2011), outros grupos que trabalham em parceria com nosso grupo também observaram a mesma dificuldade em manter o cultivo de iPSC canina em matrigel (comunicação pessoal) ${ }^{1}$. Tais diferenças devem ser ponderadas, pois é sabido que alterações morfológicas podem ser o reflexo de uma expressão gênica alterada; uma vez que tal expressão encontra-se prejudicada em células com formação atípica, isso deve ser considerado em análises de quantificação da expressão gênica.

Figura 26 - Diferenças morfológicas observadas no cultivo de iPSC canina em diferentes substratos
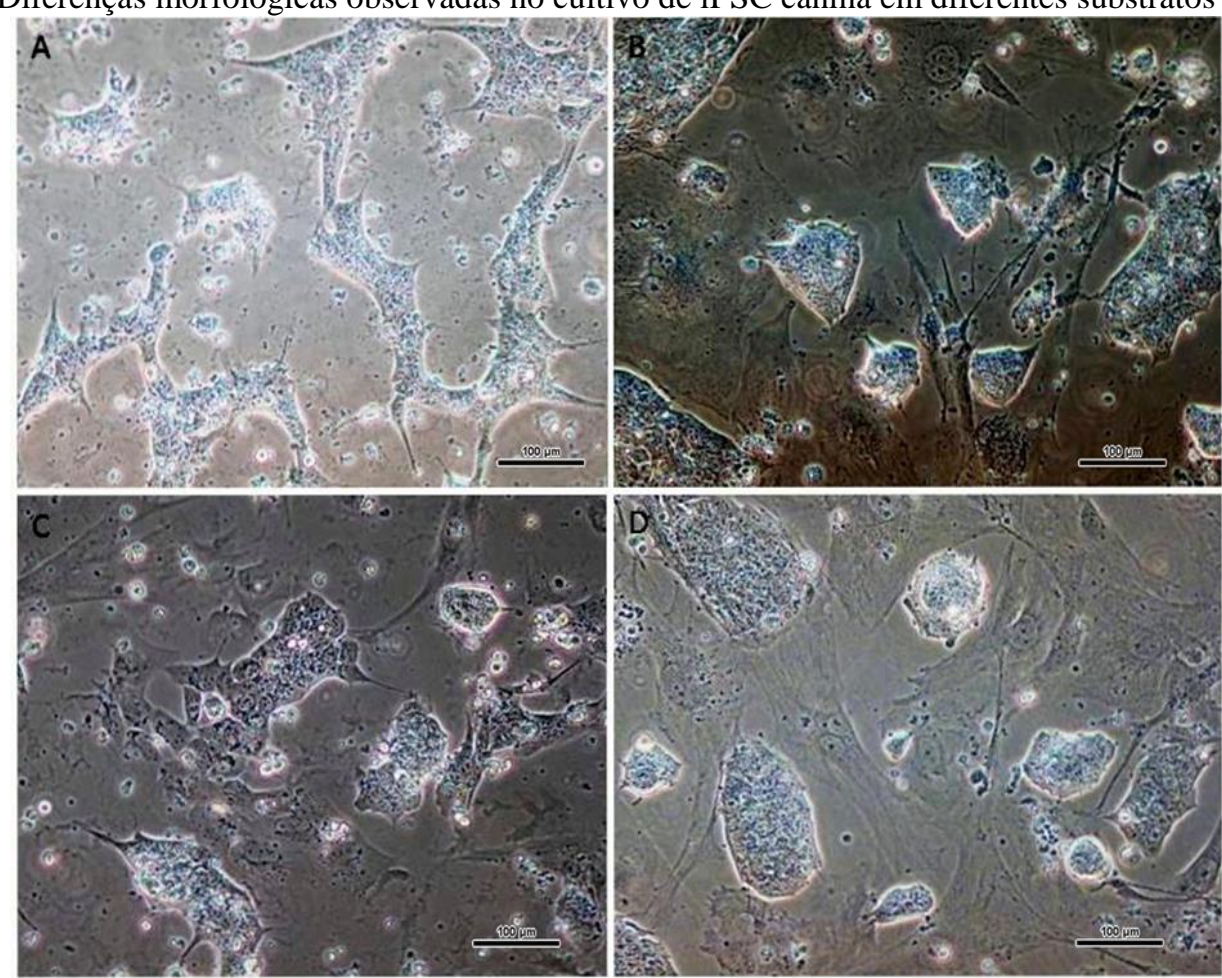

Fonte: (GONÇALVES, N. N., 2015).

Legenda: Diferenças morfológicas observadas no cultivo de iPSC canina em diferentes substratos. A e B) linhagem 4 em matrigel e MEF. C e D) linhagem 6 em matrigel e MEF. Observar que nas imagens de cultivo em MEF (B e D) as colônias têm borda definida e morfologia típica de células pluripotentes reprogramadas, o que não se reproduz no cultivo em matrigel (A e C).

\footnotetext{
${ }^{1}$ Informação fornecida pelo Dr. Sehwon Koh, da Universidade da Carolina do Norte (NCSU), em discussão científica informal por email.
} 
As colônias mostraram morfologia típica com aproximandamente 15 a 20 dias pós transdução e passaram a ser repicadas manualmente, tal procedimento foi realizado através da manipulação de agulhas $30 \mathrm{G}$ acopladas a seringas de $1 \mathrm{~mL}$ estéreis, na qual as MEFS foram recortadas do contorno das colônias, e estas por sua vez, foram recortadas em pedaços menores (Figura 27), os pedaços menores foram transportados para uma nova placa com MEFs com auxílio de uma micropipeta de $10 \mu 1$, e em seguida os pedaços foram delicadamente fixados à MEF com uma lâmina de bisturi.

Figura 27 - Imagem sob estereomicroscópio mostrando o procedimento para repique manual

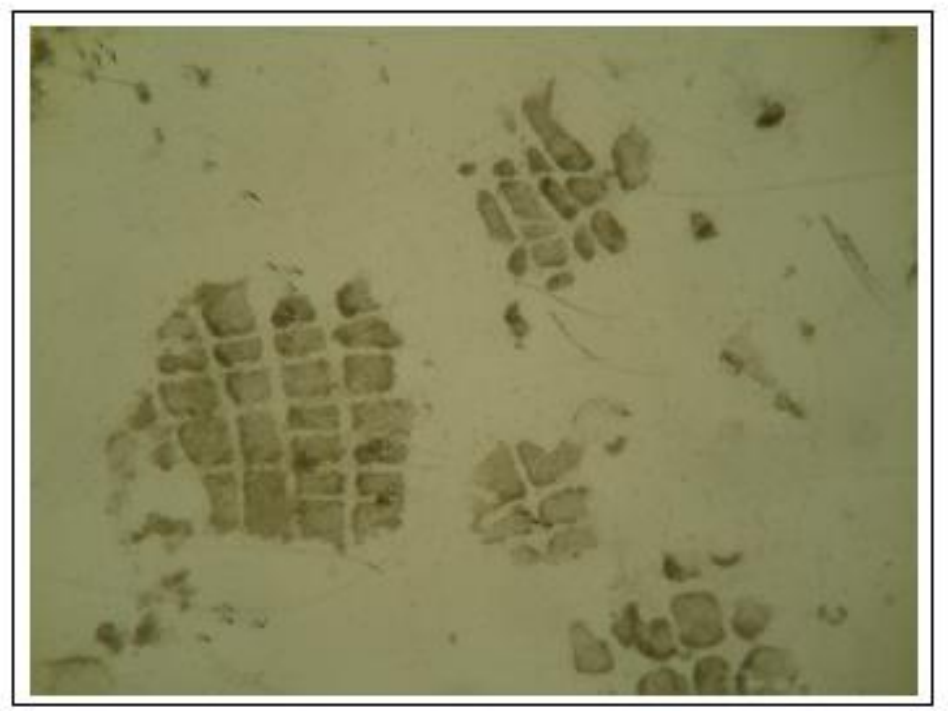

Fonte: (BRESSAN, F., 2013).

Legenda: Imagem sob estereomicroscópio mostrando o procedimento para repique manual.

De todos os protocolos foram obtidas 66 linhagens clonais, das quais 18 (dos protocolos 4,5 e $6 \mathrm{~h}+\mathrm{m}$ e h) se mantiveram por no máximo 10 passagens e 10 se mantiveram por $15 \mathrm{ou}$ mais passagens e foram utilizadas para todos os testes de caracterização in vitro, sendo $7 \mathrm{~h}+\mathrm{m}$ e 3h. Destas, quatro linhagens estão representadas (Figura 28 A-H) com alta expressão de fosfatase alcalina indicando se tratar de uma célula indiferenciada com potencial de autorrenovação. A fosfatase alcalina é uma enzima hidrolase presente em altos níveis na membrana de células pluripotentes indiferenciadas, sendo portanto, um teste in vitro para comprovação da pluripotência de tais linhagens IPSCs. 
Figura 28 - Linhagens clonais expressando fosfatase alcalina
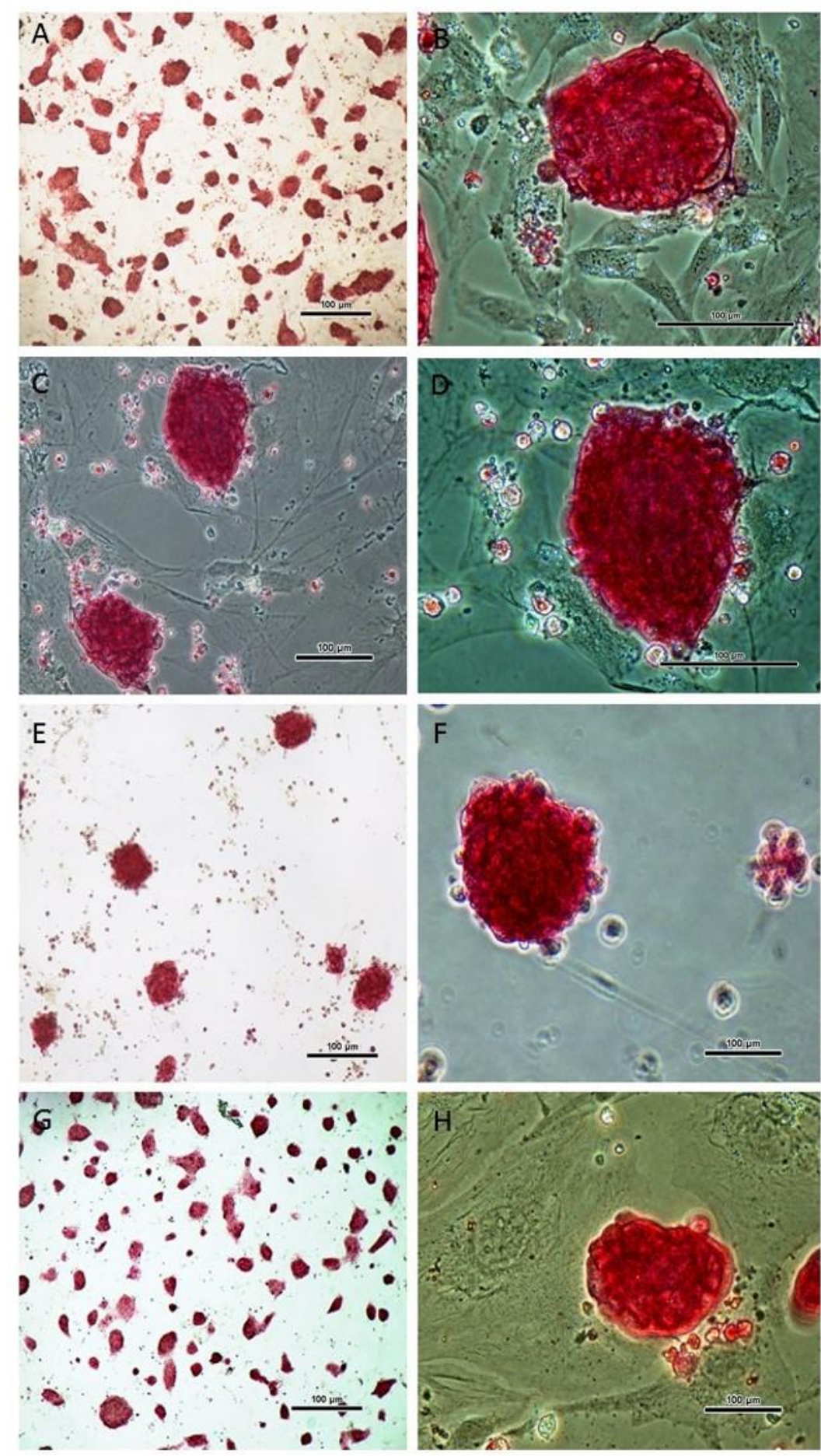

Fonte: (GONCALVES, N. N., 2015).

Legenda: Linhagens clonais expressando fosfatase alcalina. A e B) colônia 4 - $5^{\text {a }}$ pasagem, aumento 5x e 40x. C e D) colônia 5 - $4^{a}$ passagem, aumento 10x e 40x. E e F) colônia 6 - $4^{a}$ passagem, aumento 5x e 20x. G e H) colônia $11-8^{\mathrm{a}}$ passagem, aumento $5 \mathrm{x}$ e 20x.

As IPSC caninas cultivadas foram repicadas manualmente na primeira e segunda passagem e a partir deste estágio, o repique foi mantido com uma adaptação do método enzimático com Tryple Express (Gibco) uma vez que a maioria dos protocolos indica o uso de 
$1 \mathrm{~mL}$ por poço e incubação por cerca de 3 mim para que todas as colônias se desprendam da placa, este procedimento foi visivelmente (alterações morfológicas) prejudicial ao desenvolvimento das colônias, a partir de tal circunstância, estabelecemos uma adaptação, onde apenas $500 \mu \mathrm{l}$ de Tryple eram adicionados por placa de $35 \mathrm{~mm}$, sem incubação e imediatamente a mesma quantidade de meio de cultivo era adicionado, lavando a placa delicadamente até que as colônias se soltassem. As células apresentaram uma recuperação completa após este procedimento (morfologia adequada), que foi padronizado e mantido para todas as passagens e linhagens clonais selecionadas (Figura 29 A-C).

Figura 29 - Morfologia das colônias após repique enzimático adaptado com Tryple Express
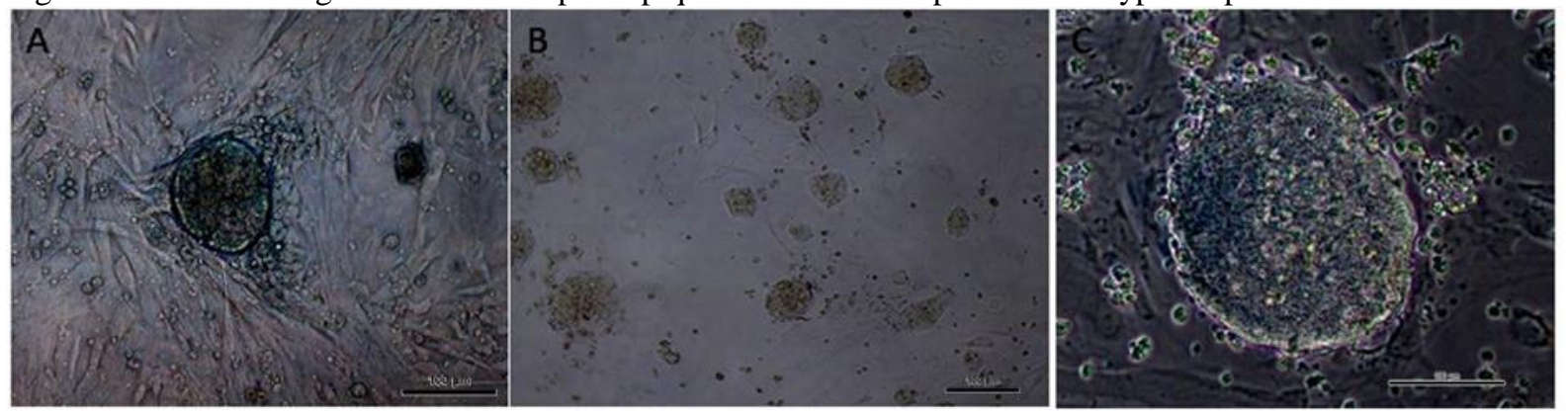

Fonte: (GONÇALVES, N. N., 2015).

Legenda: Morfologia das colônias após repique enzimático adaptado com Tryple Express. A, B e C) colônia 4 após 4 passagens com Tryple. 10x, 5x e 40x, respectivamente.

A formação de corpos embrióides mostrou-se eficiente em todas as linhagens avaliadas, sendo em sua maioria, com morfologia adequada e borda definida (Figura 30 A-H). Os corpos embrióides são estruturas esféricas, agregados tri-dimensionais, formadas in vitro a partir de células pluripotentes, abrigando em tal estrutura o desenvolvimento de diversos tipos celulares e tecidos. A formação desta estrutura caracteriza o potencial de diferenciação das células de pluripotência induzida. 
Figura 30 - Formação de corpos embrióides cultivados em agarose, fotografados após 48 horas de cultivo
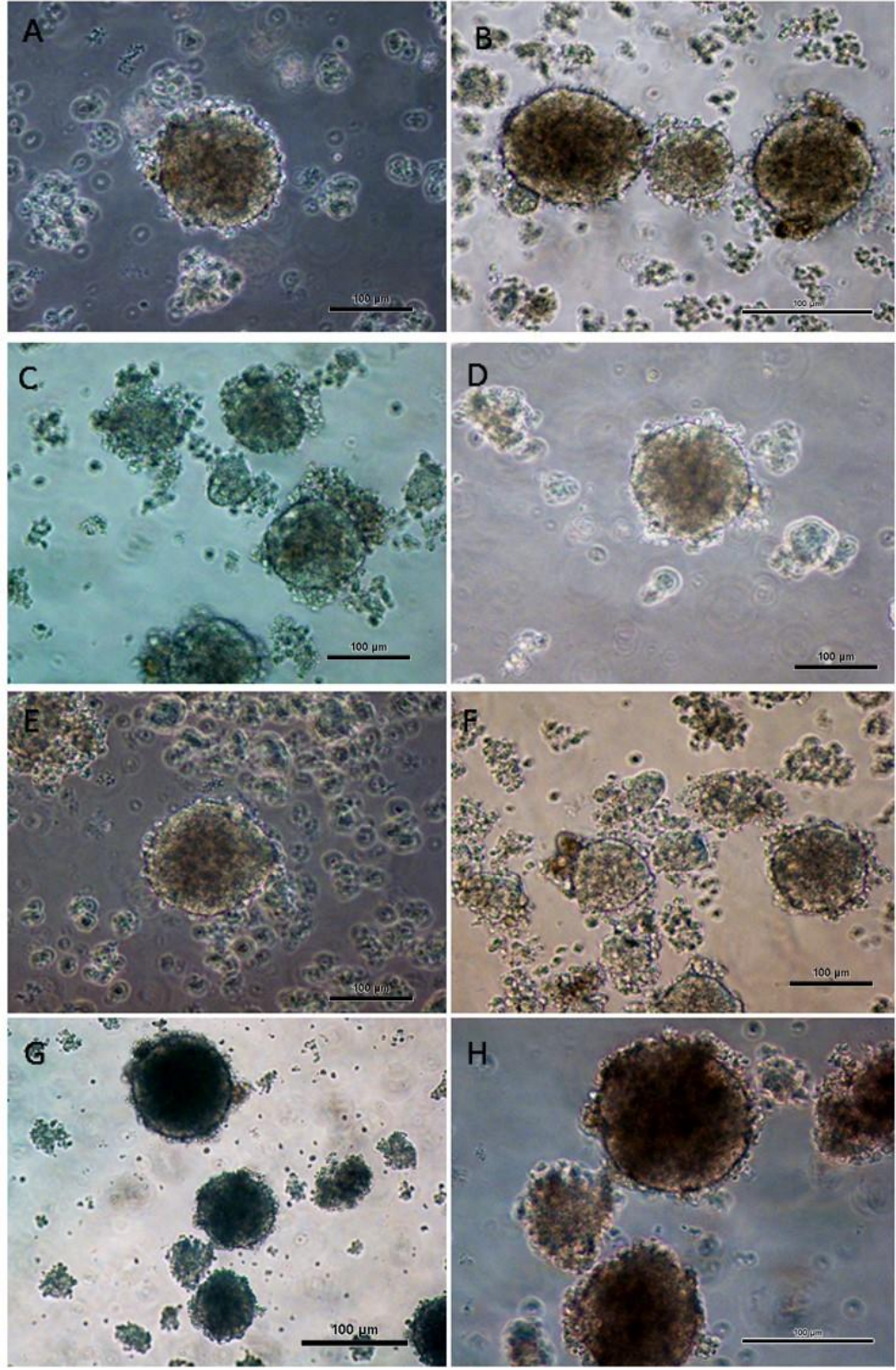

Fonte: (GONÇALVES, N. N., 2015).

Legenda: Formação de corpos embrióides cultivados em agarose, fotografados após 48 horas de cultivo. A e B) linhagem 4- $16^{\mathrm{a}}$ passagem. C e D) linhagem $5-11^{\mathrm{a}}$ passagem. E e F) linhagem $6-11^{\mathrm{a}}$ passagem. G e H) linhagem $11-9^{\mathrm{a}}$ passagem. 20x.

A análise de diferenciação in vitro espontânea, foi feita após a formação de corpos embrióides, sem auxílio de kits específicos de diferenciação, onde foi possível observar células com morfologia fibroblastóide (Figura 31). 
Figura 31 - Diferenciação in vitro após 5 dias de cultivo em gelatina
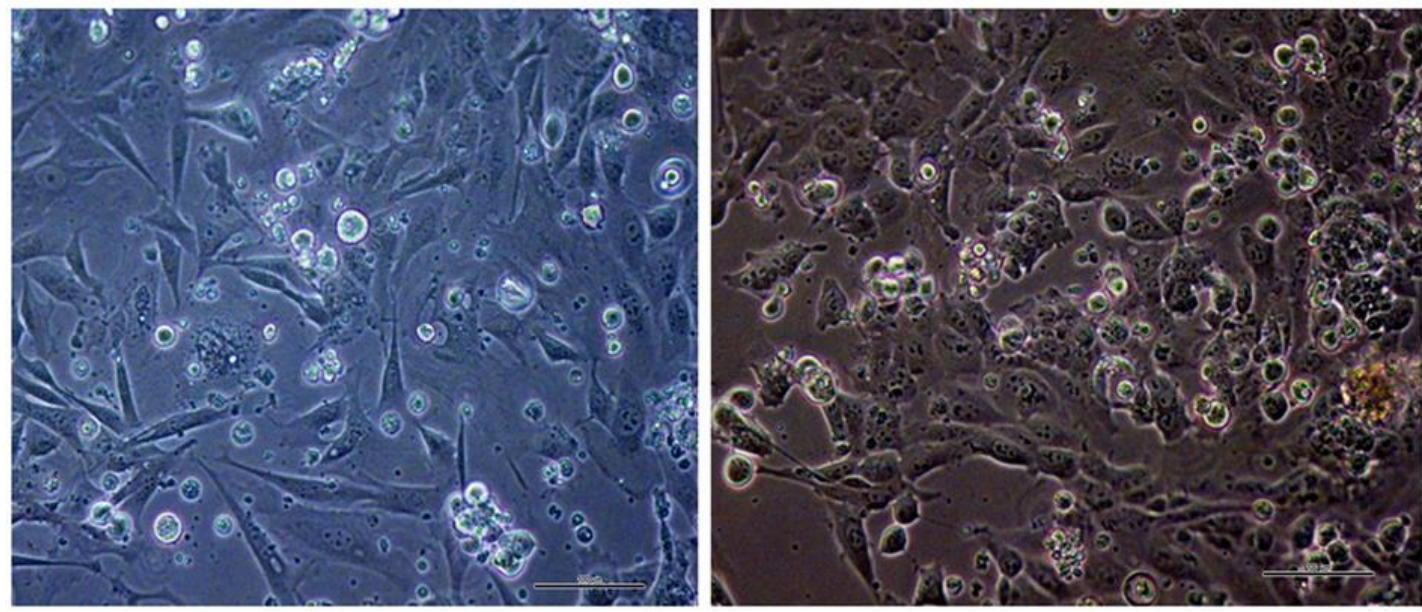

Fonte: (GONÇALVES, N. N., 2015).

Legenda: Diferenciação in vitro após 5 dias de cultivo em gelatina. Foi possível observar por toda a placa a mudança de morfologia com características fibroblastóides. Linhagem $4 \mathrm{~h}+\mathrm{m}-16^{\mathrm{a}}$ passagem, 40x.

As linhagens foram avaliadas quanto a expressão dos fatores de pluripotência endógenos, comprovando uma reprogramação completa onde o maquinário da célula assume o controle da pluripotência. Pudemos observar alta expressão de OCT4 e SOX2, sendo que estes foram normalizados com a expressão de fibroblastos embrionários não reprogramados. As colônias 4, 5 e 6 foram cultivas em matrigel, para evitar a contaminação com MEF (que expressa OCT4 e pode ser detectado, camuflando os resultados), desta forma, apurando nossas análises e demonstrando alta expressão de ambos os fatores nas linhagens avaliadas, a média das colônias avaliadas foi gerada a partir de triplicatas biológicas, para obtenção de desvio padrão, que se mostrou alto para tais análises, evidenciando a diferença entre as linhagens reprogramadas, demonstrando que cada linhagem clonal é única no processo de reprogramação e pode apresentar variações de padrão (Figuras 32 e 33). 
Figura 32 - Gráfico representando a expressão de SOX2 nas linhagens IPS canina, comparadas a fibroblastos fetais não reprogramados, em unidades arbitrárias

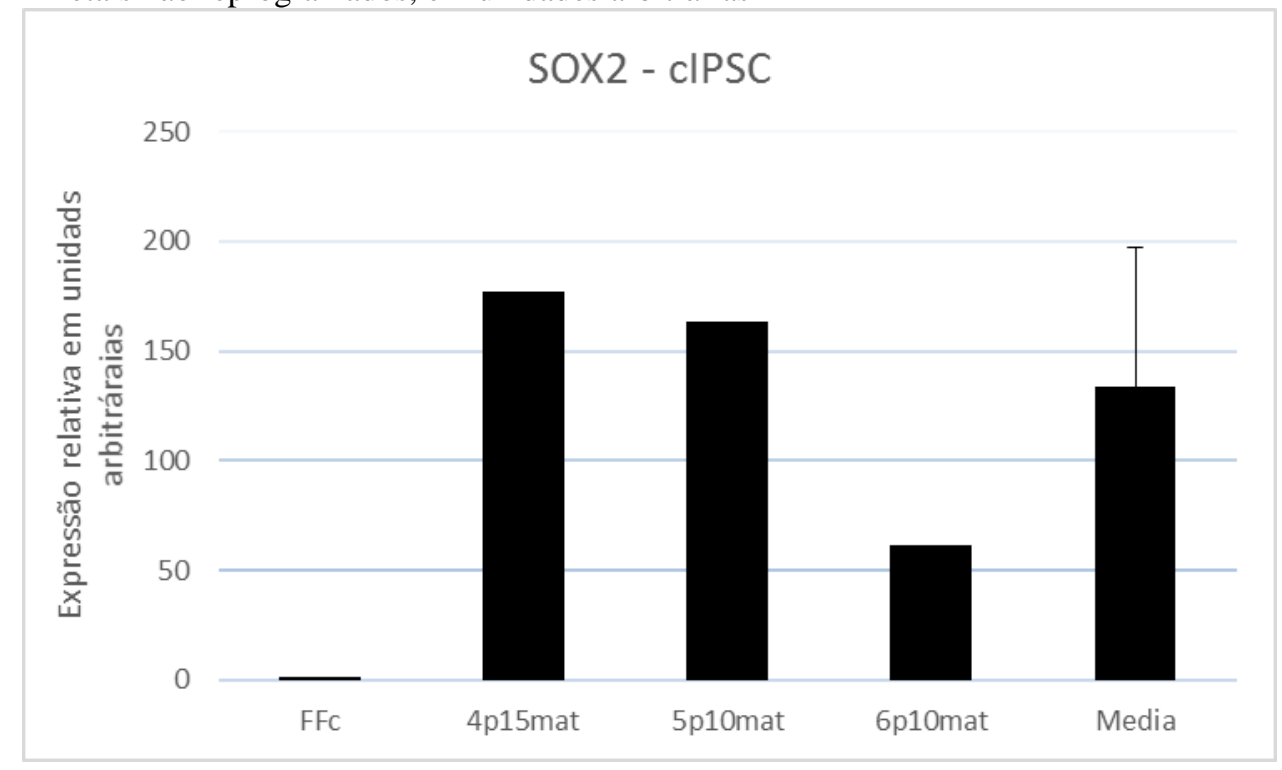

Fonte: (GONÇALVES, N. N., 2015).

Legenda: Gráfico representando a expressão de SOX2 nas linhagens IPS canina, comparadas a fibroblastos fetais não reprogramados, em unidades arbitrárias. Amostras mescladas como triplicatas biológicas para obtenção de média e desvio padrão.

Figura 33 - Gráfico representando a expressão de OCT4 nas linhagens IPS canina, comparadas a fibroblastos fetais não reprogramados, em unidades arbitrárias

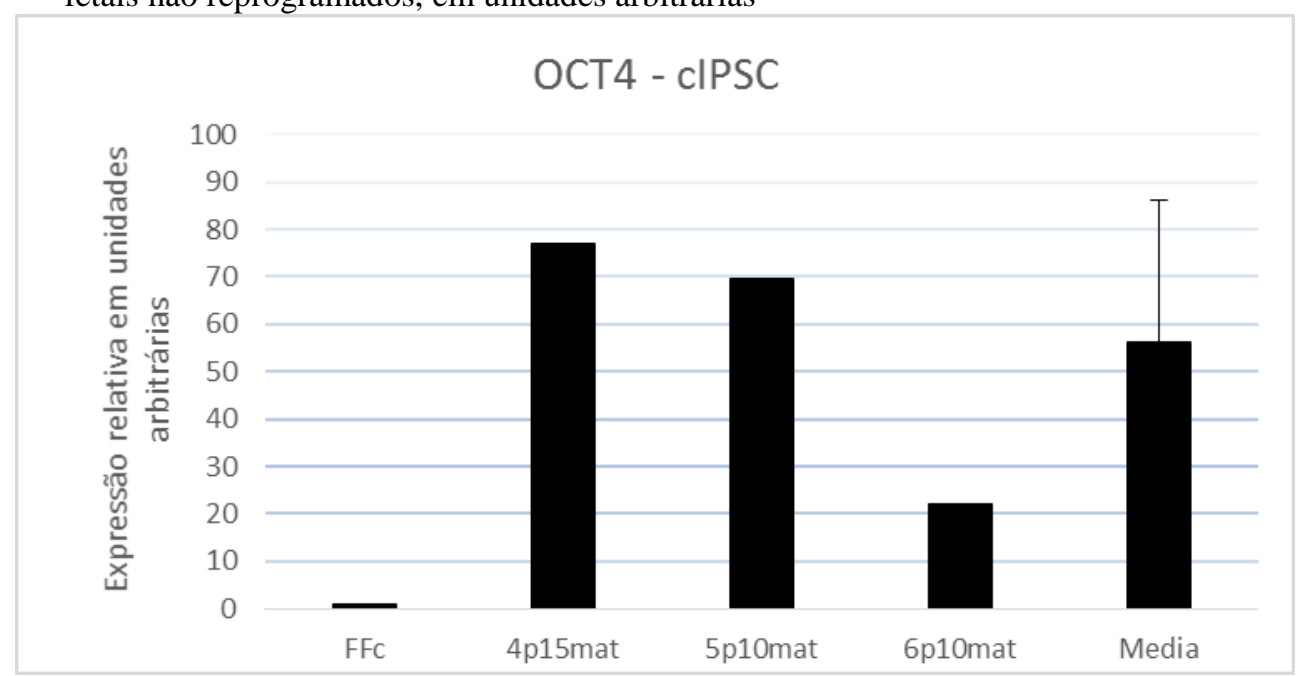

Fonte: (GONÇALVES, N. N., 2015).

Legenda: Gráfico representando a expressão de OCT4 nas linhagens IPS canina, comparadas a fibroblastos fetais não reprogramados, em unidades arbitrárias. Amostras mescladas como triplicatas biológicas para obtenção de média e desvio padrão. 
Assim como comprovado através da expressão gênica, foi observada a expressão das proteínas com os anticorpos para OCT4, SOX2 e NANOG (Figura 34).

Figura 34 - Detecção da proteína OCT4, SOX2 e NANOG em linhagens clonais positivas, sob microscopia óptica e de fluorescência

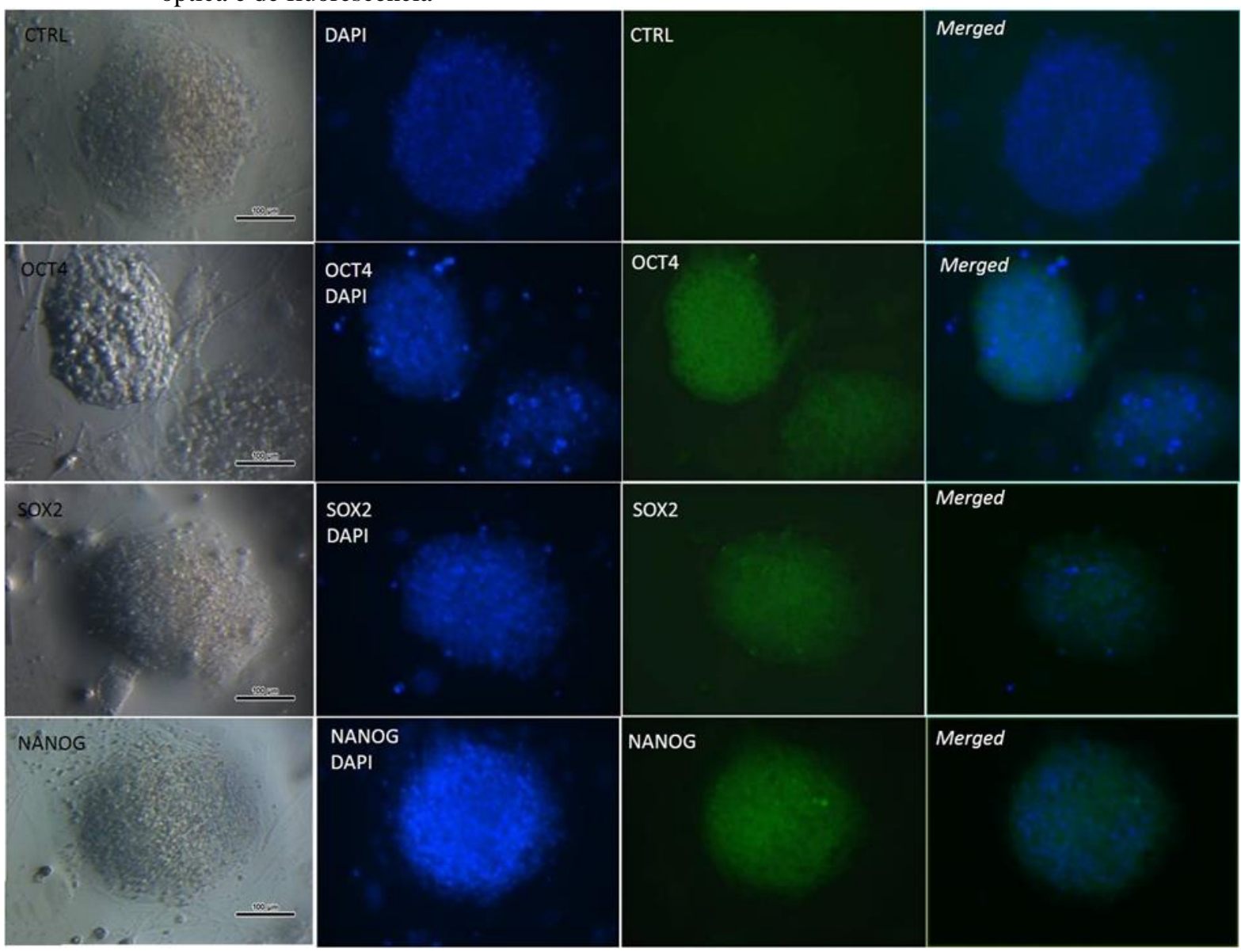

Fonte: (GONÇALVES, N. N., 2015).

Legenda: Detecção da proteína $O C T 4$, SOX2 e NANOG em linhagens clonais positivas, sob microscopia óptica e de fluorescência. Imagens merged (sobrepostas) da fluorescência positiva com a coloração nuclear por DAPI.

O cariótipo canino é considerado o mais difícil de se trabalhar, com 78 cromossomos, dos quais 76 são autossomos, de morfologia acrocêntrica com uma alteração de tamanho muito pequena. A padronização do cariótipo canino para os cromossomos de 1-21 pode ser lida por técnicas convencionais de coloração, os demais 17 pares são muito difíceis de serem identificados. Com o objetivo de facilitar esse processo, o grupo do Dr. Breen em 1999 desenvolveram sondas fluorescentes por DOP-PCR a partir de cromossomos de cão selecionados por sorted. Cada sonda foi usado por hibridização fluorescente para identificar o cromossomo correspondente, um a um identificando os 78 cromossomos, padronizando a identificação dos 17 pares não visualizados por técnicas convencionais (BREEN et al., 1999). 
O grupo do Dr. Breen pioneiro nesse delineamento experimental, tem publicado diversos trabalhos aumentando a acurácia do entendimento para o genoma canino com tais sondas. Os experimentos desenvolvidos com sondas FISH para identificar possíveis anomalias cromossomais nas iPS caninas, foi desenvolvido na Universidade da Carolina do Norte em parceria com Dr. Breen e o Dr. Piedrahita.

Os cromossomos da linhagem $4 \mathrm{~h}+\mathrm{m}$ em $15^{\mathrm{a}}$ passagem foram contados pela técnica de coloração DAPI que oferece a possibilidade de melhor compreensão da estrutura do cromossomo, estes foram lidos em fluorescência adequada, apresentando 78 cromossomos, comprovando sua origem canina (Figura 35 A) a coloração DAPI invertida foi feita para comprovar que não existem cromossomos duplicados (Figura 35 B). Os cromossomos foram então hibridizados com sondas centroméricas (Figura 36 C), não sendo detectado qualquer tipo de anomalia nesta leitura inicial.

Figura 35 - Dados de contagem cromossomal de iPS canina com coloração DAPI e avaliação por hibridização in situ (FISH)

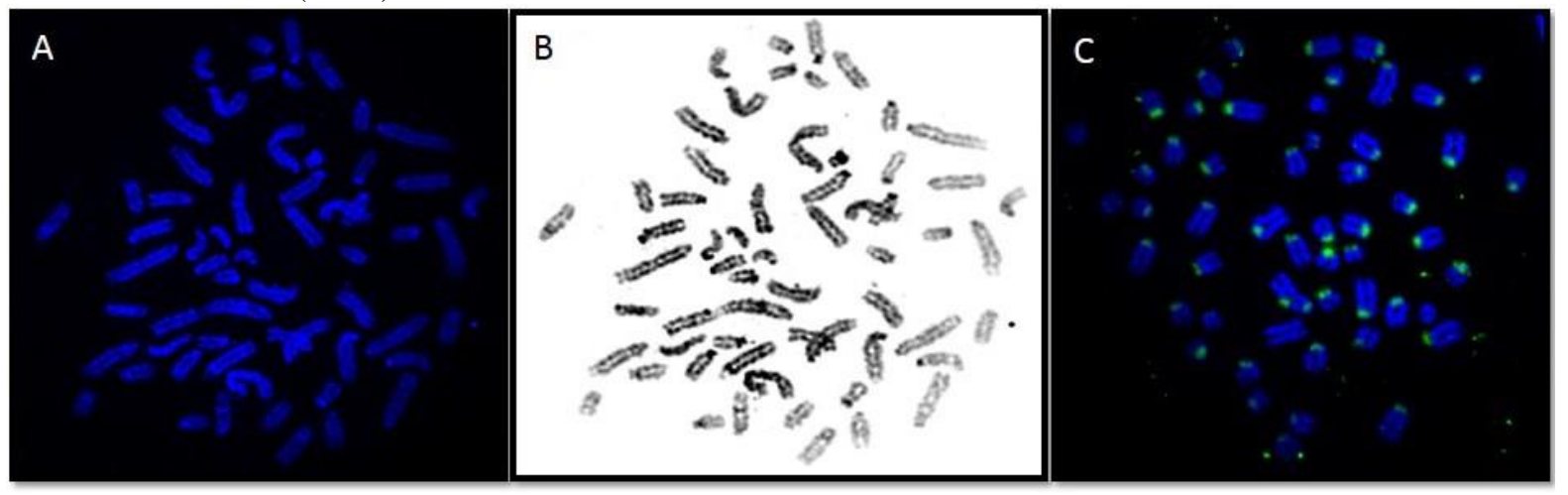

Fonte: (GONÇALVES, N. N., 2015).

Legenda: Dados de contagem cromossomal de iPS canina com coloração DAPI capturada em microscópio de fluorescência e avaliação por hibridização in situ (FISH) com sondas centroméricas.

Para a comprovação da pluripotência in vivo as linhagens $4 \mathrm{~h}+\mathrm{mOSKM}$ e 12 hOSKM foram administradas de forma subcutânea em camundongos imunossuprimidos (Figura $36 \mathrm{~A}$ ), $\mathrm{O}$ animal que foi inoculado com a linhagem $4 \mathrm{~h}+\mathrm{m}$ apresentou formação tumoral após 120 dias da inoculação, e então foi observado por 4 semanas, para acompanhamento do desenvolvimento da massa teratogênica (36 B-D) antes da eutanásia e avaliação histopatológica. O animal que recebeu a linhagem $12 \mathrm{~h}$ não apresentou formação macroscópica, porém foi eutanasiado para avaliação histopatológica, sendo que nenhuma alteração celular ou tecidual foi encontrada. 
Figura 36 - Injeção subcutânea de linhagem clonal 4 h+m ciPS em Balb/c nude

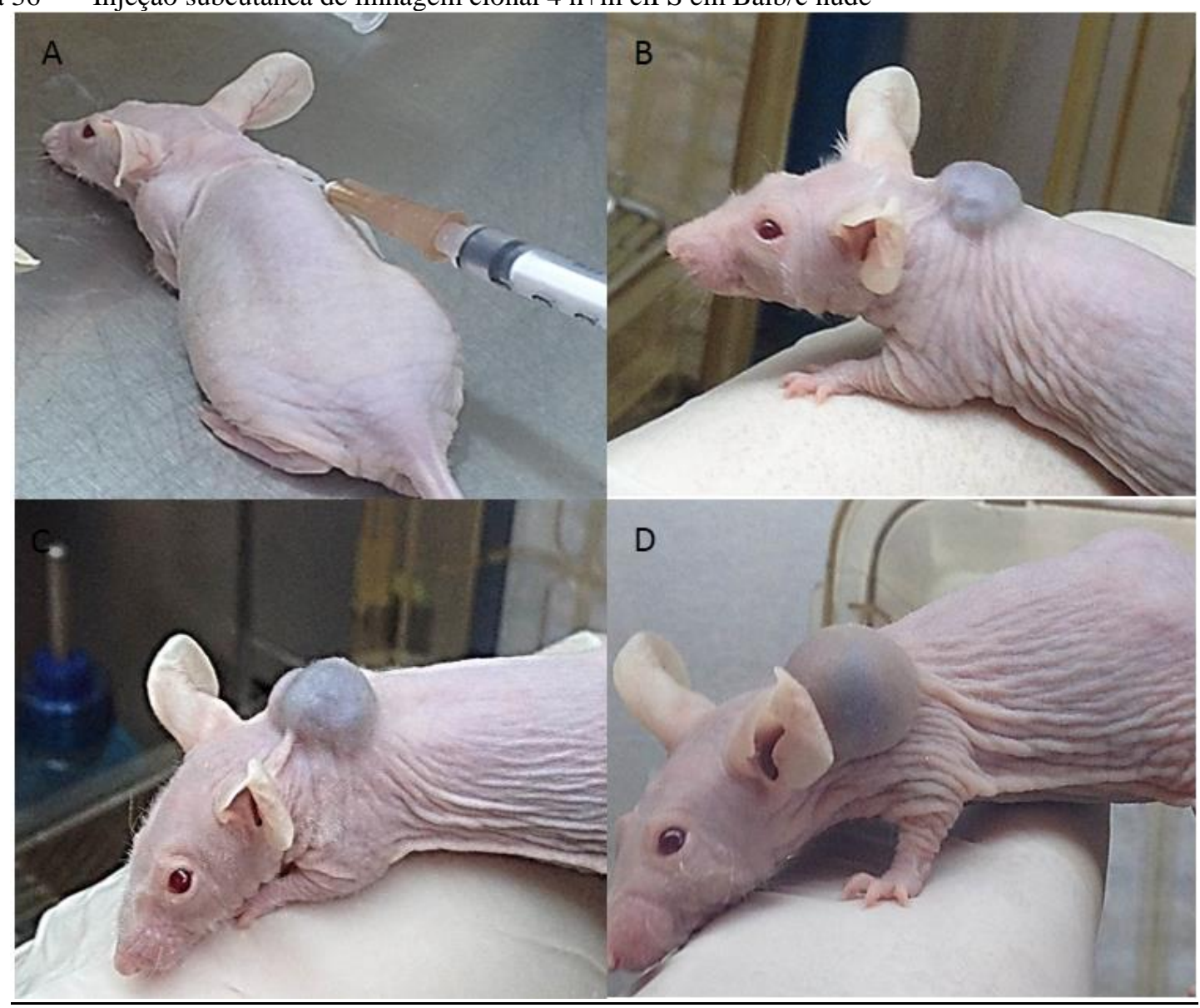

Fonte: (GONÇALVES, N. N., 2015).

Legenda: Injeção subcutânea de linhagem clonal 4h+m ciPS em Balb/c nude (A), formação de massa teratogênica após 120 dias mantida por 1 semana (B), 2 semanas (C), 3 semanas (D), antes da eutanásia para avaliação histopatológica.

Os animais foram eutanasiados em câmara de $\mathrm{CO}^{2}$, confirmado por deslocamento cervical, de acordo com protocolo aprovado e estabelecido no comitê de bioética da FMVZ/USP e FZEA/USP, em seguida, foram avaliados por médico veterinário quanto a possíveis alterações macroscópicas nos demais órgãos. Todos os órgãos foram mensurados e se apresentaram com arquitetura preservada. $\mathrm{O}$ animal que desenvolve a massa teratogênica não apresentou quaisquer outras alterações macro e microscópicas (Figuras 37 e 38) assim como o animal que não apresentou a formação tumoral mostrou tecidos e órgãos com características normais (Figuras 39 e 40). Após processamento histológico, os cortes de ambos os animais foram avaliados por médico veterinário patologista e não apresentaram anomalias celulares, com arquitetura preservada, bem como parênquima e tecidos glandulares sem alterações. (Figuras 37, 38, 39, 40). 
Figura 37 - Avaliação macroscópica e microscópica dos órgãos para o Nude com formação tumoral

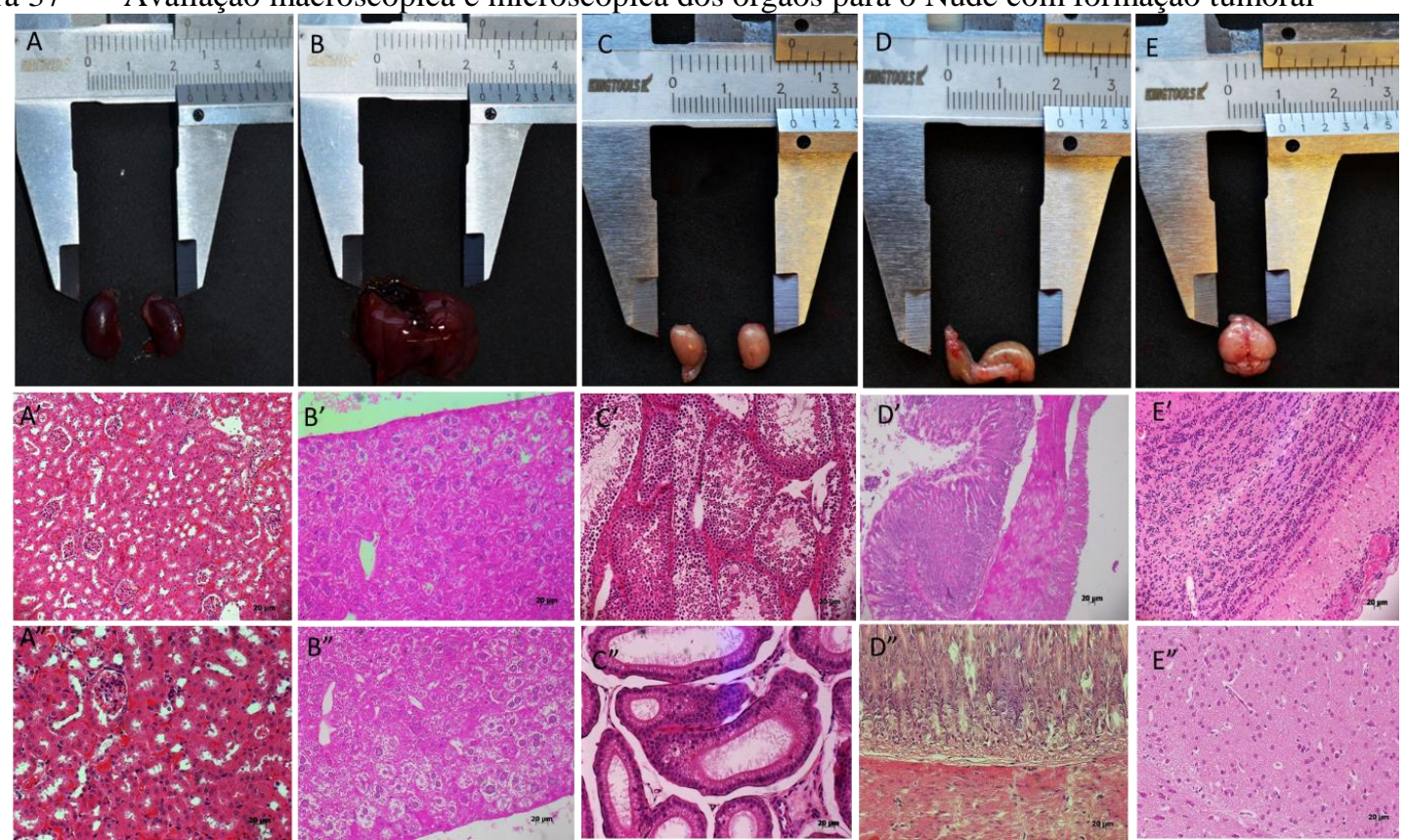

Fonte: (GONÇALVES, N. N., 2015).

Legenda: Avaliação macroscópica dos órgãos para o Nude com formação tumoral: rins (A), fígado (B), testículos (C), estômago (D) e cérebro (E), todos com mensuração e anatomia normais. Fotomicrografias dos órgãos avaliando os constituintes celulares que se apresentaram com arquitetura preservada, distribuição histológica sem alterações, bem como parênquima e regiões glandulares preservadas. Objetiva de 10x (A', B', C', D', E') e objetiva de 20x (A”, B”, C”, D”, E”).

Figura 38 - Avaliação macroscópica e microscópica dos órgãos para o Nude com formação tumoral

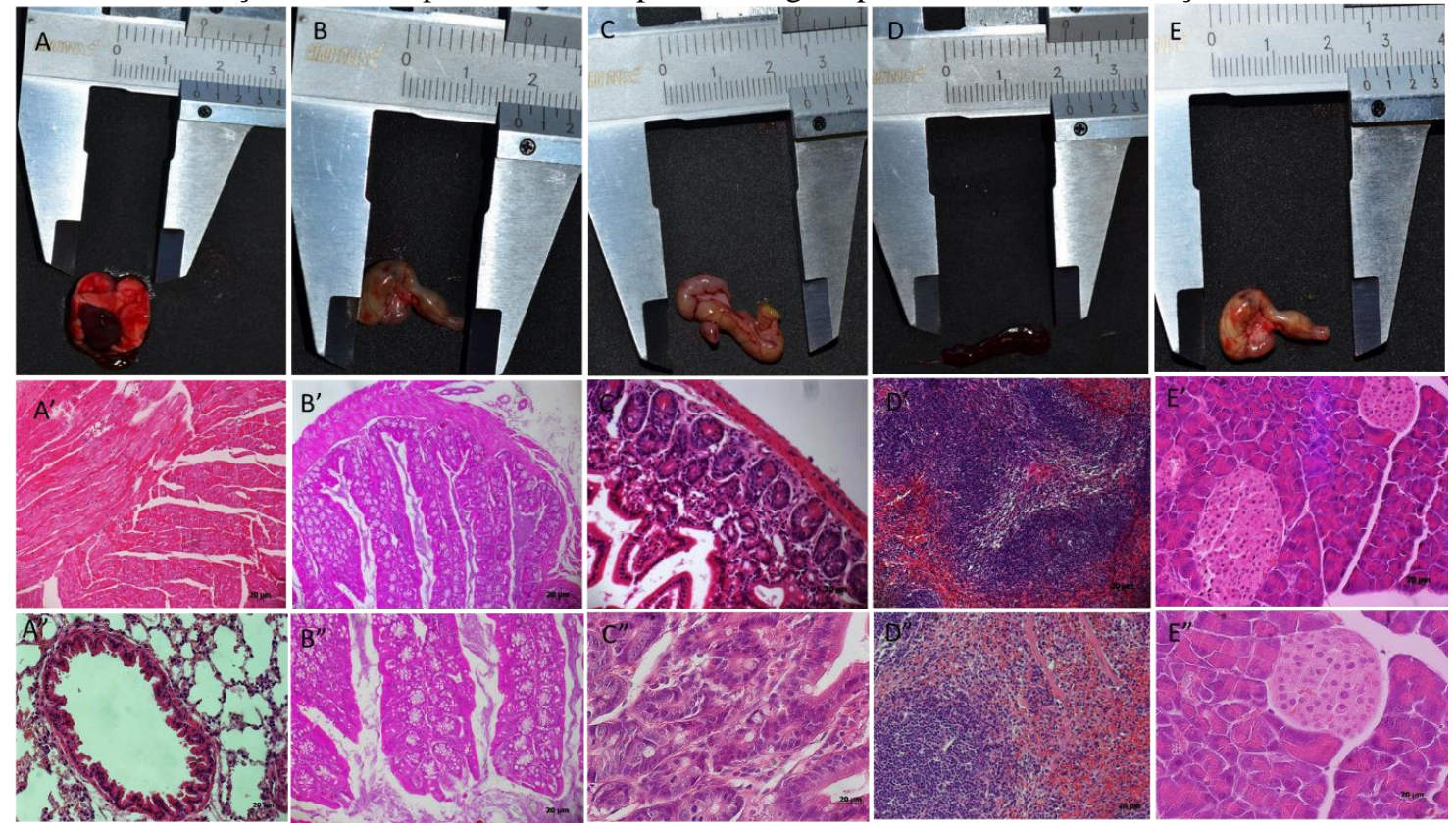

Fonte: (GONÇALVES, N. N., 2015).

Legenda: Avaliação macroscópica dos órgãos para o Nude com formação tumoral macroscópica: Coração e pulmão (A), intestino grosso (B), intestino delgado (C), baço (D), pâncreas (E), todos com mensuração e anatomia normais. Fotomicrografias dos órgãos avaliando os constituintes celulares que se apresentaram com arquitetura preservada, distribuição histológica sem alterações, bem como parênquima e regiões glandulares preservadas. Objetiva de 10x (A', B', C', D', E') e objetiva de 20x (A", B", C", D", E"). 
Figura 39 - Avaliação macroscópica e microscópica dos órgãos para o Nude sem formação tumoral

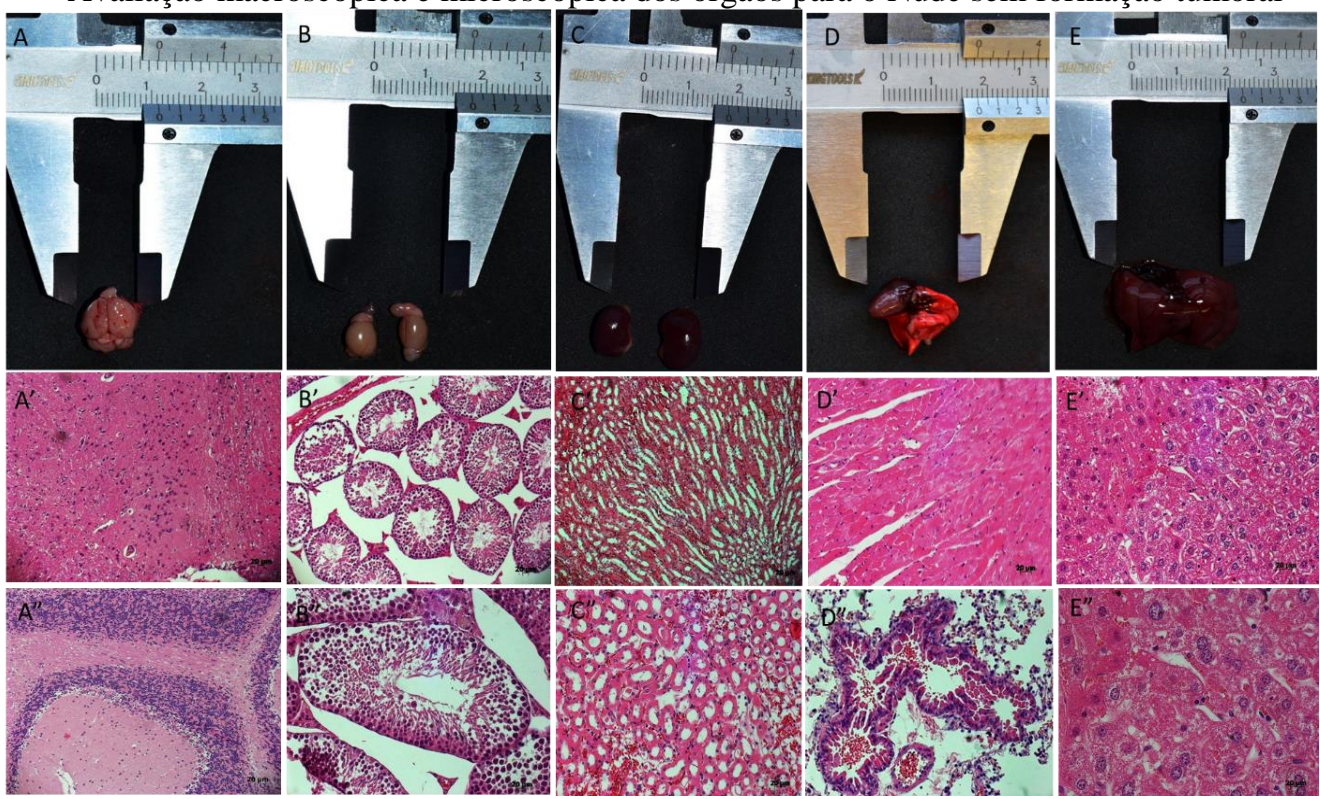

Fonte: (GONÇALVES, N. N., 2015).

Legenda: Avaliação macroscópica dos órgãos para o Nude sem formação tumoral macroscópica: Cérebro (A), testículos (B), rim (C), coração e pulmão (D) e fígado (E), todos com mensuração e anatomia normais. Fotomicrografias dos órgãos avaliando os constituintes celulares que se apresentaram com arquitetura preservada, distribuição histológica sem alterações, bem como parênquima e regiões glandulares preservadas. Objetiva de 10x (A', B', C', D', E') e objetiva de 20x (A”, B”, C”, D”, E”).

Figura 40 - Avaliação macroscópica e microscópica dos órgãos para o Nude sem formação tumoral

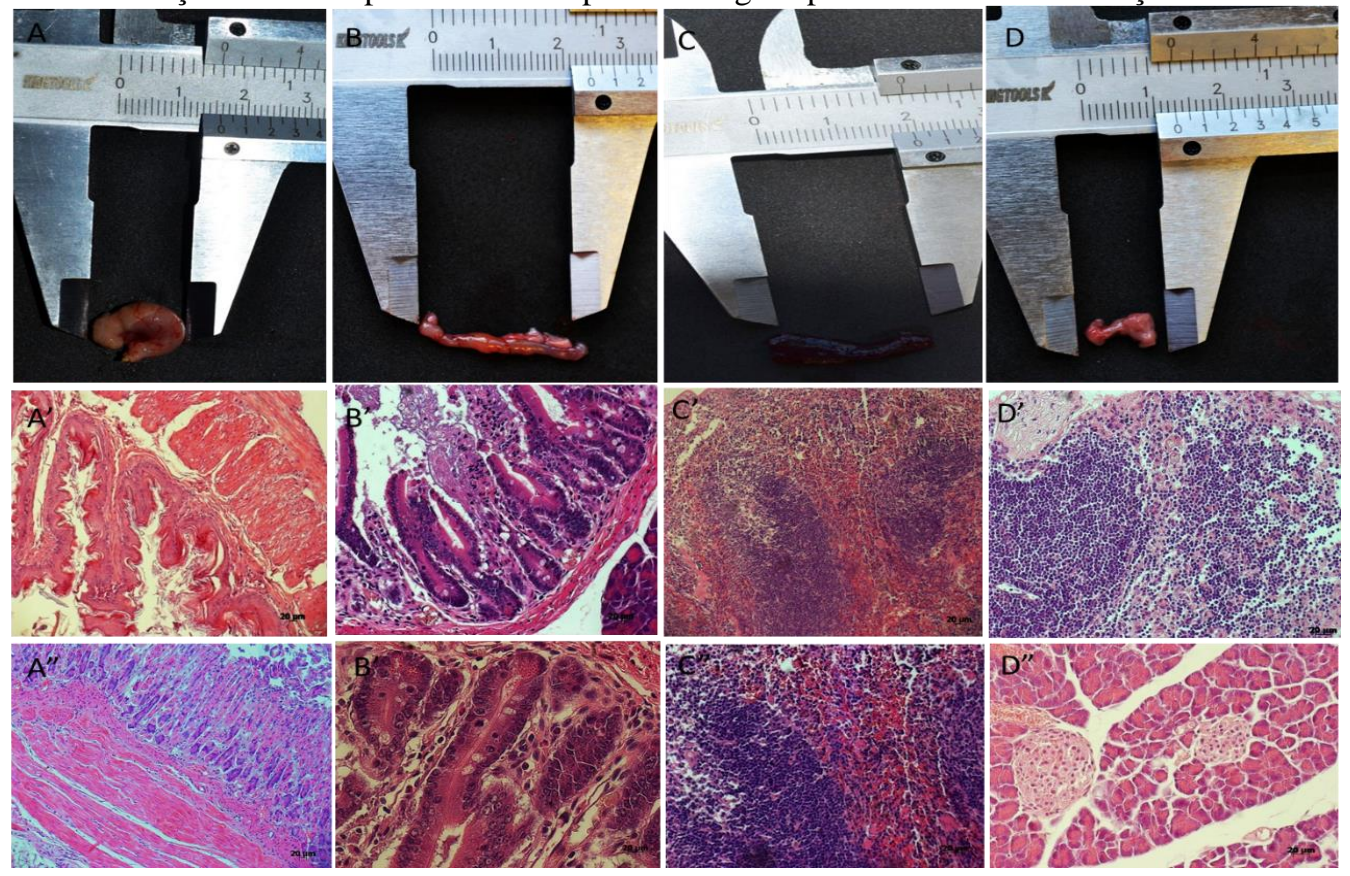

Fonte: (GONÇALVES, N. N., 2015).

Legenda: Avaliação macroscópica dos órgãos para o Nude sem formação tumoral macroscópica: Estômago (A), intestino delgado (B), baço (C) e pâncreas (D), todos com mensuração e anatomia normais. Fotomicrografias dos órgãos avaliando os constituintes celulares que se apresentaram com arquitetura preservada, distribuição histológica sem alterações, bem como parênquima e regiões glandulares preservadas. Objetiva de 10x (A', B', C', D', E') e objetiva de 20x (A”, B', C”, D”). 
A massa tumoral, mantida por 4 semanas, estava localizada em região cervical com aproximadamente $1 \mathrm{~cm}$, era circunscrita, firme, de contornos irregulares, não aderida, não serada ou revestida de pele íntegra além de muito vascularizada. O tumor era heterogêneo, com intensa anisocitose, presença de trabéculas de tecido muscular, células eusinofílicas, bem como características de tecido mielóide distribuídas pelo parênquima, células de citoplasma amplo e claro, característico de tecido adiposo, além de células multinucleadas e presença de diversos nucléolos, indicando intensa proliferação celular além de altamente vascularizado (Figura $41 \mathrm{~A}, \mathrm{~B}, \mathrm{C}$ ).

Figura 41 -Avaliação microscópica da massa teratogênica localizada em região cervical

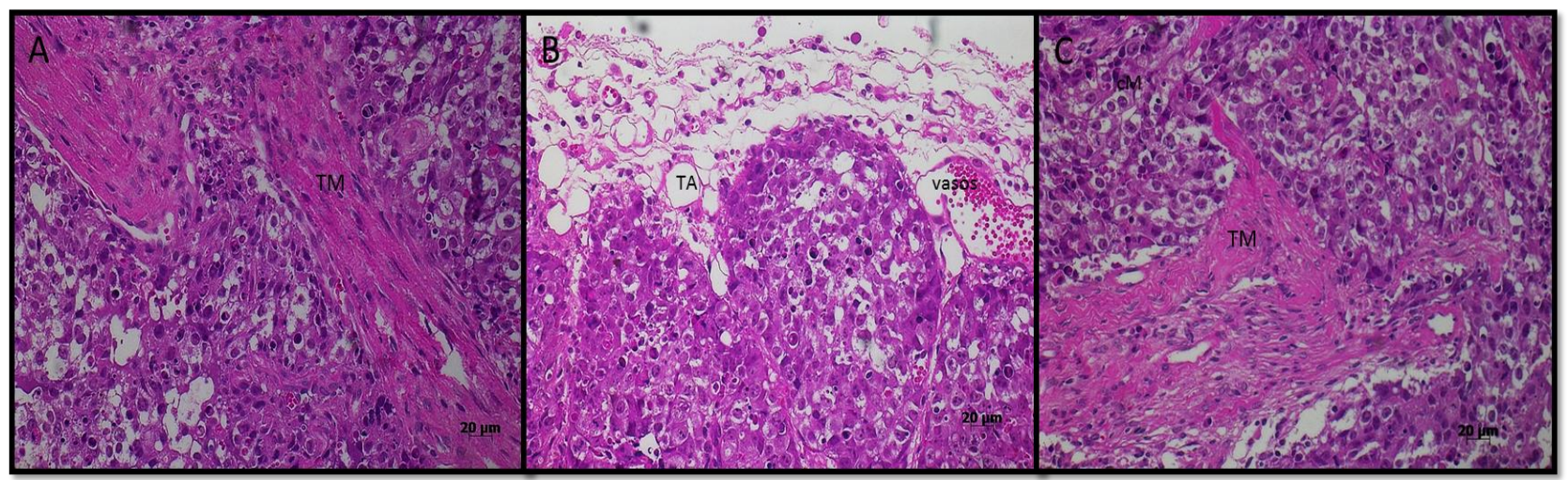

Fonte: (GONÇALVES, N. N., 2015).

Legenda: Fotomicrografia da massa tumoral evidenciando trabéculas de tecido muscular difuso (TM) (A e C),

(B) com vascularização intensa (vasos) e células com características de tecido adiposo (TA) e ainda (C') células multinucleadas (cM). Objetiva 20x. 


\subsection{Discussão}

Desde a primeira geração de iPs, feita por Yamanaka et al. (2006) com a introdução dos fatores gênicos por vetor retroviral, muitas variáveis deste processo vem surgindo, o objetivo de todas estas tentativas é estabelecer um protocolo cada vez mais reprodutível, com altas taxas de eficiência e sem integração viral, situação ideal para seu uso em testes clínicos e terapia celular. Até o momento, muitas vertentes foram publicadas com tais objetivos, produzindo linhagens cada vez mais aplicáveis a testes clínicos e terapêuticos.

Diversos vetores não integrados vêm ganhando espaço no processo de reprogramação, como o vetor epissomal, onde porções do Epstein-Barr herpes vírus humano é usado para criar um vetor capaz de transfectar sem empacotamento viral, resultando no oriP/EBNA1 (Epstein-Barr antígeno nuclear 1), que também pode ser removido por seleção de drogas específicas. Este vetor passa por replicação extracromossomal estável, apenas uma vez por ciclo celular, sem se integrar ao genoma da célula. No entanto, a taxa de eficiência de geração de iPS com vetores epissomais é muito baixa (YU et al., 2009). Okita et al. (2011) aumentaram a taxa de eficiência com a supressão de p53, pois é sabido que a proteína P53, supressora de tumores, repara danos celulares, e desempenha um papel crítico na limitação do desenvolvimento e progressão celular malígna. Quaase todos os cânceres estão associados com defeitos nesta via ou mutação (ALAM et al., 2015) Com sua supressão, as células alteradas conseguem se proliferar com mais facilidade, associado a 1-MYC/c-MYC, proliferador celular, resultando no aumento de eficiência da geração de iPS.

Nossos resultados com vetor epissomal só foram positivos quando acrescidos do fator $c$ MYC, semelhante aos experimentos de Okita et al. (2011), porém a taxa de eficiência ainda foi muito baixa, apesar de tais achados abrirem caminho para a produção de cIPSCs mais seguras e sem a integração viral. É sabido que a integração viral ainda é uma barreira para as aplicações clínicas, muitos artigos tem reportado a ocorrência de aneuploidias, variações no numero de cópias, ou mutações pontuais em células iPS. As metodologias de não integração vêm sendo desenvolvidas para minimizar o impacto do processo de reprogramação no genoma (STEICHEN et al., 2015). Aliado ao $c$-MYC, identificado três décadas atrás, capaz de acelerar o processo de replicação celular, apesar de sua colocação importante no desenvolvimento tumoral (DANG, 2010; WASYLISHEN; PENN, 2010). Numerosos fatores de transcrição regulatórios interagem com $c-M Y C$ e este gene está associado com ativação e 
diferenciação celular, metabolismo, apoptose e interação com a regulação de outros genes. Tipicamente, este gene vem sendo muito estudado quanto a sua relação com neoplasias, linfomas, mielomas, entre outros (NIE et al., 2012). Esta forte relação com a proliferação celular pode explicar o sucesso da reprogramação epissomal quando associada a tal gene.

Schlaeger et al. (2015) descreveram um estudo comparativo entre os métodos não integrativos de reprogramação, definindo em porcentagem a taxa de sucesso quanto ao surgimento de colônias hiPSC para o método epissomal (93\%), Sendai-vírus (FUSAKI et al., 2009) (94\%) comparados ao método integrado por lentivírus (100\%), em contraste com o método por mRNA (WARREN et al., 2010) com baixa eficiência (27\%), mostrando que é possível obter altas taxas de sucesso com a reprogramação epissomal, apesar do processo lentiviral ainda ser mais eficaz.

A avaliação da expressão dos genes $O C T 4$ e $S O X 2$, essenciais para a reprogramação, associados a proteínas repórteres, nos permite avaliar o comportamento bem como a influência de cada fator no processo de reprogramação. A separação por sorting, apenas das células que se integraram ao gene, aumenta em teoria a eficiência de reprogramação, permitindo uma avalição biológica dos mecanismos de integração rastreados por uma proteína reporter. Rizzino (2013) descreveu em sua revisão a importância destes dois fatores de transcrição e o quanto estão conectados, discutindo seu papel essencial na embriogênese e que ambos trabalham na manutenção da pluripotência ativando outros genes, sabendo-se que uma pequena alteração nos níveis de ambos é suficiente para induzir a diferenciação. Papapetrou et al. (2009) observou que o aumento dos níveis de OCT4 é capaz de manter os níveis de SOX2, KLF4 e c-MYC constantes, e a diminuição dos níveis de OCT4 diminui drasticamente a frequencia de reprogramação. Outro trabalho constatou que a diminuição dos índices de SOX2 aumentam a frequência de células iPS parcialmente reprogramadas (YAMAGUCHI et al., 2011). De forma geral, estes estudos deixam claro que as taxas de OCT4 e SOX2 precisam ser cuidadosamente controlados para otimização da produção de células iPS.

Inicialmente, com o trabalho de Yamanaka et al. (2006) as iPS foram geradas por vetores retrovirais derivados de MLV e HIV-1, porém tais vetores já foram diretamente associados com ativação de pro-oncogenes, mais do que os derivados de HIV-1 (MONTINI et al., 2006). Com o objetivo de otimizar o processo, surgiram os vetores de expressão simultânea de múltiplos genes, que se tornaram possíveis com a inserção de sequências intercalantes, como o peptídeo 2A ou iRES (sítio interno de ligação ao ribossomo) entre quadros de leitura (ORF), assim, diversos vetores policistrônicos foram desenvolvidos a partir destas combinações, acreditando-se que com a expressão multipla dos fatores em um único 
vetor, a taxa de reprogramação poderia ser significativamente melhorada, e o procedimento menos laborioso e mais seguro (CHANG et al., 2009; SOMMER et al., 2009). A princípio, reprogramações geradas por tais vetores produzem células mais próximas do perfil de célulastronco embrionárias verdadeiras (CHIN et al., 2010). Tais vetores, utilizados na reprogramação lentiviral, gerou um alto número de colônias na maioria dos protocolos desenvolvidos neste experimento.

O primeiro trabalho com iPs canina, data de 2010 (SHIMADA et el., 2010) onde linhagens foram estabelecidas com o protocolo Yamanaka de infecção retroviral OSKM dependentes de LIF e bFGF e suplementadas com 2i, porém tais linhagens não foram caracterizadas de forma completa até a formação de massa teratogênica. O segundo estudo para a espécie canina foi publicado 2 anos depois, onde Luo et al. (2011) usaram OSKM associado a um gene repórter, e geraram linhagens iPs LIF e bFGF dependentes.

Já em 2012, Withworth et al, fez uso dos vetores lentivirais, mas não usou a formação policistrônica, gerando células iPs com os fatores OSKM somado a LIN28 e NANOG suplementando tais células com LIF, comprovando que as colônias mantidas com a combinação de LIF e bFGF ou apenas bFGF se diferenciavam de forma espontânea, e as colonias mantidas apenas com LIF se mantiveram indiferenciadas por pelo menos 40 passagens numa eficiência de reprogramação de $0,0007 \%$.

Em 2013 Koh e colaboradores geraram células iPs de cão a partir do sistema retroviral, dependentes de LIF e ou LIF e bFGF e ainda avaliaram alterações cromossomais em tais linhagens identificando anomalias nos cromossomos 4, 8, 13 e 16. Nishimura et al. (2013) obtiveram colonias de iPS canina dependentes de LIF e bFGF por infecção lentiviral e posteriormente diferenciadas com sucesso em plaquetas, evidenciando o avanço nas pesquisas de iPS em animais domésticos.

Comparados aos dados já publicados, as iPSCs caninas aqui descritas foram obtidas com o vetor policistrônico STEMCCA desenvolvido por Sommer et al. (2009) e mantidas dependentes apenas de bFGF, além de resistentes ao repique enzimático com Tryple Express se mantendo estáveis por pelo menos 20 passagens, e positivas paara todos os testes in vitro e in vivo de caracterização, apresentando ainda cromossomos com estrutura adequada e sem indícios de anomalias, baseado na hibridização por FISH. Porém, algumas de nossas linhagens foram estabelecidas com a infecção dupla, ou seja, hOSKM + mOSKM, para a confirmação de qual fator efetivamente reprogramou as células ou se ambos se integraram ao genoma, faz-se necessário um experimento de PCR tempo real com primers específicos para cada vetor, provando como ocorreu o processo de integração. Nenhum dos trabalhos descritos 
até o momento para a espécie em questão trabalharam com a combinação de vetores, reforçando a necessidade de se comprovar tal processo inovador, uma vez que as linhagens mais estáveis foram obtidas de tal procedimento.

Diversos trabalhos tem sido desenvolvidos com a hibridização in situ, para a avaliações de anomalias sexuais (CASSATELLA et al., 2013; DIANOVSKY et al., 2013), principalmente para o diagnóstico de tumores (POORMAN et al., 2015; SHAPIRO et al., 2015). Desde os primeiros estudos com iPSC até o momento, muito tem sido discutido quanto aos efeitos genéticos e epigenéticos de tal reprogramação induzida. A técnica FISH vem sendo utilizada para esclarecimentos de anomalias. Terai et al. (2013) investigaram o tamanho do telômero cromossomal de células iPSC humanas por FISH, mostrando seu encurtamento conforme o aumento do número de passagens e ainda anomalias como a trissomia do cromossomo $\mathrm{X}$; esta relação de encurtamento versus número de passagens foi comprovado também por Ji et al (2013) em células iPSC suínas com o uso de sondas hibridizadas. Em camundongos foram avaliadas 127 linhagens de iPSC com alta incidência de trissomia nos cromossomos 8 e 11 (BEN-DAVID; BENVENISTY, 2012).

Para as iPSCs geradas a partir de animais domésticos tal investigação ainda é escassa. Koh et al. (2013) avaliaram a instabilidade cromossomal em células iPSCs canina, identificando regiões comuns de anomalias em células iPSC de cães, camundongos e humanos, especificamente nos cromossomos 8 e 13 e ainda regiões específicas (4 e 16). Nossos resultados avaliando anomalias cromossomais por hibridização FISH, são preliminares para conclusões, porém não foi detectada nenhuma anomalia estrutural nas avaliações iniciais, vale ressaltar que as células iPS são únicas e o micro ambiente no qual são mantidas, in vitro ou in vivo, pode ter efeito significativo quanto as mudanças cromossomais observadas (KOH et al., 2013), assim, podemos sugerir que a ausência de anomalias indica uma indução da pluripotência mais segura.

Schlaeger et al. (2015) também descrevem de forma comparativa o cariótipo de linhagens hIPSC geradas por diferentes metodologias, mostrando que aquelas geradas por sistema retroviral tinham altas taxas de aneoploidia $(13,5 \%)$, as geradas com mRNA apresentaram os menores índices $(2,3 \%)$ seguidas pelo sistema lentiviral $(4,5 \%)$ e Sendaivírus $(4,6 \%)$ de reprogramação, embasando nossos resultados cromossomais sem alterações, a partir de células ciPSC geradas com sistema lentiviral.

A formação de tumores na produção de iPSCs é caracterizada como um teste essencial para a comprovação da pluripotência, o primeiro artigo caracterizando iPS a partir de fibroblastos caninos (SHIMADA et al., 2010) não relata a formação de tumores, a partir de 
então, Luo et al. em 2011 também não tiveram sucesso na formação tumoral de células iPS caninas, sugerindo que a injeção de tais células em camundongos imunossuprimidos talvez não fosse a forma mais adequada para a formação tumoral. Whitworth et al. (2012) injetaram 8 linhagens em nudes, e obtiveram apenas 2 formações tumorais que eram basicamente formadas por células germinativas-like (PGCs). Em cães o único artigo que relata formações tumorais verdadeiras e provenientes dos 3 folhetos, foi Koh et al. em 2013, onde a formação tumoral era detectada após um período médio de 60 dias. Neste estudo, a formação tumoral só foi evidente macroscopicamente 120 dias pós inoculação e mantida para desenvolvimento por 4 semanas. A avaliação histológica sugere um grande número de células indiferenciadas, porém em sua predominância de origem mesodérmica, sugerindo que a manutenção desta massa por 4 semanas pode não ter sido tempo suficiente para que todas as células se diferenciassem em células dos três folhetos embrionários.

Vaskova et al. (2013) revisaram o comportamento epigenético das células iPSCs quanto a sua "memória" somática, e demonstraram algumas características adquiridas durante a reprogramação ou ainda assinaturas no epigenoma e transcriptoma remanescentes do tecido doador. Essa assinatura residual no tecido somático é chamado de "memória epigenética" e este fenômeno pode influenciar o comportamento de células reprogramadas, bem como as possibilidades de sua aplicação, uma vez que a célula somática reprogramada, quando em processo de diferenciação, tende a retornar a suas origens devido a essa memória celular, se diferenciando com mais facilidade em seus precursores originais. Isso poderia explicar a prevalência de células mesodermais no tumor gerado, onde as colônias iPSCs canina, geradas a partir de fibroblastos, podem ter se diferenciado considerando sua memória epigenética, retornando a sua origem mesodermal. 


\section{CONCLUSÃO}

$\checkmark \quad$ Neste estudo foi proposto o estabelecimento da linhagem iPSC canina a partir de fibroblastos fetais, bem como a compreensão de outros protocolos e fatores envolvidos na reprogramação, com o objetivo de aumentar a eficácia deste processo ou ainda conhecer os fatores envolvidos no mesmo.

A reprogramação por vetor epissomal foi possível, quando associada ao fator $c-M Y C$, que aumenta a proliferação celular, mostrando um caminho alternativo na obtenção de tais linhagens, sem a integração viral, mas que ainda precisa ser melhor estabelecido.

$\checkmark \quad$ Descrevemos linhagens de fibroblastos fetais caninos expressando diferentes fatores de transcrição humanos relacionados à pluripotência. As células caninas se mostraram sensíveis à integração e expressão do OCT4 e SOX2 humano em uma eficiência elevada, raramente observado em outras espécies.

As células iPS canina foram resistentes ao repique enzimático e geradas independentes de LIF, positivas para todos os testes de caracterização in vitro, bem como o teste in vivo, formando tumores predominantemente mesodérmicos. As linhagens foram avaliadas quanto a sua integridade cromossomal por hibridização FISH e apesar de preliminares, tais resultados não mostraram anomalias, fato este essencial para um processo de reprogramação eficaz e mais seguro. 


\section{REFERENCIAS}

AKSOY, I.; JAUCH, R.; ERAS, V.; BIN, A. C.; CHEN, J.; DIVAKAR, U.; NG, C. K.; KOLATKAR, P. R.; STANTON, L. W. Sox transcription factors require selective interactions with $O C T 4$ and specific transactivation functions to mediate reprogramming. Stem Cells, v. 31, n. 12, p. 2632-46, 2013.

ALAM, M. J.; KUMAR, S.; SINGH, V.; SINGH, RK. Bifurcation in Cell Cycle Dynamics Regulated by p53. PLoS One, v. 10, n. 6, p. e0129620, 2015.

AMIT, M.; ELDOR, J. I. Derivation and spontaneous differentiation of human embryonic stem cells. Journal of Anatomy, v. 200, p. 225-232, 2002.

ANOKYE-DANSO, F.; TRIVEDI, C. M.; JUHR, D.; GUPTA, M.; CUI, Z.; TIAN, Y.; ZHANG, Y.; YANG, W.; GRUBER, P. J.; EPSTEIN, J. A.; MORRISEY, E. E. Highly efficient miRNA-mediated reprogramming of mouse and human somatic cells to pluripotency. Cell Stem Cell, v. 8, n. 4, p. 376-88, 2011.

ARNHOLD, S.; KLEIN, H.; SEMKOVA, I.; ADDICKS, K.; SCHRAERMEYER, U.; Neurally selected embryonic stem cells induce tumor formation after long-term survival following engraftment into the subretinal space. Investigative Ophthalmology \& Visual Science, v. 45, n. 12, p. 4251-5, 2004.

BAO, L.; HE, L.; CHEN, J.; WU, Z.; LIAO, J.; RAO, L.; REN, J.; LI, H.; ZHU, H.; QIAN, L.; GU, Y.; DAI, H.; XU, X.; ZHOU, J.; WANG, W.; CUI, C.; XIAO, L. Reprogramming of ovine adult fibroblasts to pluripotency via drug-inducible expression of defined factors. Cell Research, v. 21, n. 4, p. 600-608, 2011.

BEN-DAVID, U., N. BENVENISTY. High prevalence of evolutionarily conserved and species-specific genomic aberrations in mouse pluripotent stem cells. Stem Cells, v. 30, n. 4, p. 612-622, 2012.

BLOMBERG, L. A.; TELUGU, B. P. V. L. Twenty years of embryonic stem cell research in farm animals. Reproduction in Domestic Animals, v. 47, n. 4, p. 80-85, 2012.

BOYER, L. A.; LEE, T. I.; COLE, M. F.; JOHNSTONE, S. E.; LEVINE, S. S.; ZUCKER, J. P.; GUENTHER, M. G.; KUMAR, R. M.; MURRAY, H. L.; JENNER, R. G.; GIFFORD, D. K.; MELTON, D. A.; JAENISCH, R.; YOUNG, R. A. Core transcriptional regulatory circuitry in human embryonic stem cells. Cell, v. 122, n. 6, p. 947-956, 2005.

BREEN, M.; LANGFORD, C. F.; CARTER, N. P.; HOLMES, N. G.; DICKENS, H. F.; THOMAS, R.; SUTER, N.; RYDER, E. J.; POPE, M.; BINNS, M. M. FISH mapping and identification of canine chromosomes. Journal of Heredity, v. 90, n. 1, p. 27-30, 1999.

BRESSAN, F. F. Geração de células pluripotentes através da indução gênica e transferência de núcleo: modelo bovino de aquisição de pluripotência. 2013. 134 p. Tese (Doutorado) - Faculdade de Zootecnia e Engenharia de Alimentos, Universidade de São Paulo, Pirassununga, 2013. 
BREVINI, T. A.; ANTONINI, S.; PENNAROSSA, G.; GANDOLFI, F. Recent progress in embryonic stem cell research and its application in domestic species. Reproduction in Domestic Animals, v. 43, n. 2, p. 193-9, 2008.

CAI, Y.; DAI, X.; ZHANG, Q.; DAI, Z. Gene expression of OCT4, SOX2, KLF4 and MYC (OSKM) induced pluripotent stem cells: identification for potential mechanisms. Diagnostic Pathology, v. 10, n. 1, p. 35, 2015.

CASSATELLA, D.; MARTINO, N. A.; VALENTINI, L.; GUARICCI, A. C.; CARDONE, M. F.; PIZZI, F.; DELL'AQUILA, M. E.; VENTURA, M. Male infertility and copy number variants (CNVs) in the dog: a two-pronged approach using Computer Assisted Sperm Analysis (CASA) and Fluorescent In Situ Hybridization (FISH). BMC Genomics, v. 14, n.921, p. 1-10, 2013.

CHANG, C. W.; LAI, Y. S.; PAWLIK, K. M.; LIU, K.; SUN, C. W.; LI, C.; SCHOEB, T. R.; TOWNES, T. M. Polycistronic lentiviral vector for "hit and run" reprogramming of adult skin fibroblasts to induced pluripotent stem cells. Stem Cells, v. 27, n. 5, p. 1042-9, 2009. 10.1002/stem.39.

CHIN, M. H.; PELLEGRINI, M.; PLATH, K.; LOWRY, W. E. Molecular analyses of human induced pluripotent stem cells and embryonic stem cells. Cell Stem Cell, v. 7, n.2, p. 263-9, 2010.

DANG, C. V. Enigmatic MYC conducts an unfolding systems biology aymphony. Genes Cancer, v. 1, p. 526-531, 2010.

DARABI, R.; ARPKE, R. W.; IRION, S.; DIMOS, J. T.; GRSKOVIC, M.; KYBA, M.; PERLINGEIRO, C. R. Human ES- and iPS-derived myogenic progenitors restore dystrophin and improve contractility upon transplantation in dystrophic mice. Cell Stem Cell, v. 10, n. 5, p. 610-619, 2012.

DE BARI, C.; DELLACCIO, F.; TYLZANOWSKI, P.; LUYTEN, F. Multipotent mesenchymal stem cells from adult human synovial membrane. Arthritis Rheumatism, v. 44, n. 8, p. 1928-42, 2001.

DENNING, C.; PRIDDLE, H. New frontiers in gene targeting and cloning success, application and challenges in domestic animals and human embryonic stem cells.

Reproduction, v. 126, n. 1, p. 1-11, 2003.

DIMOS, J. T.; RODOLFA, K. T.; NIAKAN, K. K.; WEISENTHAL, L. M.; MITSUMOTO, H.; CHUNG, W.; CROFT, G. F.; SAPHIER, G.; LEIBEL, R.; GOLAND, R.; WICHTERLE, H.; HENDERSON, C. E.; EGGAN, K. Induced pluripotent stem cells generated from patients with ALS can be differentiated into motor neurons. Science, v. 321, n. 5893, 2008.

DOETSCHMAN, T.; GREGG, R. G.; MAEDA, N.; HOOPER, M. L.; MELTON, D. W.; THOMPSON, S.; SMITHIES, O. Targetted correction of a mutant HPRT gene in mouse embryonic stem cells. Nature, v. 330, n. 6148, p. 576-8, 1987. 
DOSS, M. X.; KOEHLER, C. I.; GISSEL, C.; HESCHELER, J.; SACHINIDIS, A. Embryonic stem cells: a promising tool for cell replacement therapy. Journal of Cellular and Molecular Medicine, v. 8, n. 4, p. 465-473, 2004.

ESTEBAN, M. A.; WANG, T.; QIN, B.; YANG, J.; QIN, D.; CAI, J.; LI, W.; WENG, Z.; CHEN, J.; NI, S.; CHEN, K.; LI, Y.; LIU, X.; XU, J.; ZHANG, S.; LI, F.; HE, W.; LABUDA, K.; SONG, Y.; PETERBAUER, A.; WOLBANK, S.; REDL, H.; ZHONG, M.; CAI, D.; ZENG, L.; PEI, D. Vitamin C enhances the generation of mouse and human induced pluripotent stem cells. Cell Stem Cell, v. 6, n. 1, p. 71-79, 2010.

ESTEBAN, M. A.; XU, J.; YANG, J.; PENG, M.; QIN, D.; LI, W.; JIANG, Z.; CHEN, J.; DENG, K.; ZHONG, M.; CAI, J.; LAI, L.; PEI, D. Generation of induced pluripotent stem cell lines from Tibetan miniature pig. Journal of Biological Chemistry, v. 284, n. 26, p. 17634-40, 2009.

EVANS, M. J.; KAUFMAN, M. H. Establishment in culture of pluripotential cells from mouse embryos. Nature, v. 292, n. 5819, p. 154-6, 1981.

EVANS, M. J.; NOTARIANNI, E.; LAURIE, S.; MOOR, R. M. Derivation and preliminary characterization of pluripotent cell lines from porcine and bovine blastocysts.

Theriogenology, v. 33, n. 4, p.125-8, 1990.

FESTUCCIA, N.; OSORNO, R.; WILSON, V.; CHAMBERS I. The role of pluripotency gene regulatory network components in mediating transitions between pluripotent cell states. Current Opinion in Genetics \& Deveelopment, v. 23, n. 5, p. 1-8, 2013.

FUSAKI, N.; BAN, H.; NISHIYAMA, A.; SAEKI, K.; HASEGAWA, M. Efficient induction of transgene-free human pluripotent stem cells using a vector based on Sendai virus, an RNA virus that does not integrate into the host genome. Proceedings of the Japan Academy.

Series B Physical and Biological Science, v. 85, p. 348-62, 2009.

GINIS, I.; LUO, Y.; MIURA, T.; THIES, S.; BRANDENBERGER, R.; GERECHT-NIR, S.; AMIT, M.; HOKE, A.; CARPENTER, J. I.; RAO, M. S. Differences between human and mouse embryonic stem cells. Developmental Biology, v. 269, n. 2, p. 360-80, 2004.

GÓMEZ, M. C.; SERRANO, M. A.; POPE, C. E.; JENKINS, J. A.; BIANCARDI, M. N.; LÓPEZ, M.; DUMAS, C.; GALIGUIS, J.; DRESSER, B. L. Derivation of cat embryonic stem-like cells from in vitro-produced blastocysts on homologous and heterologous feeder cells. Theriogenology, v. 74, n. 4, p. 498-515, 2010.

GONÇALVES, N. N.; AMBRÓSIO, C. E.; PIEDRAHITA, J. A. Stem cells and regenerative medicine in domestic and companion animals: a multispecies perspective. Reproduction in Domestic Animals, v.4, n. 49, p. 2-10, 2014.

GORE, A.; LI, Z.; FUNG, H. L.; YOUNG, J. E.; AGARWAL, S.; ANTOSIEWICZBOURGET, J.; CANTO, I.; GIORGETTI, A.; ISRAEL, M. A.; KISKINIS, E.; LEE, J. H.; LOH, Y. H.; MANOS, P. D.; MONTSERRAT, N.; PANOPOULOS, A. D.; RUIZ, S.; WILBERT, M. L.; YU, J.; KIRKNESS, E. F.; IZPISUA BELMONTE, J. C.; ROSSI, D. J.; THOMSON, J. A.; EGGAN, K.; DALEY, G. Q.; GOLDSTEIN, L. S.; ZHANG, K. Somatic 
coding mutations in human induced pluripotent stem cells. Nature, v. 471, n. 7336, p. 63-7, 2011.

GUEST, D. J.; ALLEN, W. R. Expression of cell-surface antigens and embryonic stem cell pluripotency genes in equine blastocysts. Stem Cells Development, v. 16, n. 5, p. 789-96, 2007.

GURDON, J. B. The developmental capacity of nuclei taken from intestinal epithelium cells of feeding tadpoles. Journal of Embryology and Experimental Morphology, v. 10, p. 62240, 1962.

HAMMACHI, H.; MORRISON, G. M.; SHAROV, A. A.; LIVIGNI, A.; NARAYAN, S.; PAPAPETROU, E. P.; O’MALLEY, J.; KAJI, K.; KO, M. S. H.; PTASHNE, M.;

BRICKMAN, J. M. Transcriptional Activation by OCT4 Is Sufficient for the Maintenance and Induction of Pluripotency. Cell Reports, v. 1, n. 2, p. 1-11, 2012.

HAN, J. W.; YOON, Y. S. Induced pluripotent stem cells: emerging techniques for nuclear reprogramming. Antioxidants \& Redox Signaling, v. 15, n.7, p. 1799-1820, 2011.

HATOYA, S.; TORII, R.; KONDO, Y.; OKUNO, T.; KOBAYASHI, K.; WIJEWARDANA, $\mathrm{V}$. Isolation and characterization of embryonic stem-like cells from canine blastocysts.

Molecular Reproduction and Development, v. 73, n. 3, p. 298-305, 2006.

HAYES, B.; FAGERLIE, S. R.; RAMAKRISHNAN, A.; BARA, S.; HARKEY, M.; GRAF, L. Derivation, characterization, and in vitro differentiation of canine embryonic stem cells. Stem Cells, v. 26, n. 2, p. 465-73, 2008.

HENG, J. C.; FENG, B.; HAN, J.; JIANG, J.; KRAUS, P.; NG, J. H.; ORLOV, Y. L.; HUSS, M.; YANG, L.; LUFKIN, T.; LIM, B.; NG, H. H. The nuclear receptor Nr5a2 can replace OCT4 in the reprogramming of murine somatic cells to pluripotent cells. Cell Stem Cell, v. 6, n. 2, p. 167-74, 2010.

HOFFMAN, L. M.; CARPENTER, M. K. Characterization and culture of human embryonic stem cells. Nature Biotechnology, v. 23, n. 6, p. 699-708, 2005.

HONDA, A.; HIROSE, M.; HATORI, M.; MATOBA, S.; MIYOSHI, H.; INOUE, K.; OGURA, A. Generation of induced pluripotent stem cells in rabbits: potential experimental models for human regenerative medicine. The Journal of Biological Chemistry, v. 285, n. 41, p. 31362-31369, 2010.

HOSKEN, R. F. Embryo transfer in the dog and cat. Theriogenology, v. 68, n. 3, p. 382-385, 2007

HOTTA, A.; ELLIS, J. Retroviral vector silencing during iPS cell induction: an epigenetic beacon that signals distinct pluripotent states. Journal of Cellular Biochemistry, v. 105, n. 4, p. 94-8, 2008.

HOU, P.; LI, Y.; ZHANG, X.; LIU, C.; GUAN, J.; LI, H.; ZHAO, T.; YE, J.; YANG, W.; LIU, K.; GE, J.; XU, J.; ZHANG, Q.; ZHAO, Y.; DENG, H. Pluripotent Stem Cells Induced 
from Mouse Somatic Cells by Small-Molecule Compound. Science, v. 341, n. 6146, p. 651-4, 2013.

HUANGFU, D.; OSAFUNE, K.; MAEHR, R.; GUO, W.; EIJKELENBOOM, A.; CHEN, S. Induction of pluripotent stem cells from primary human fibroblasts with only OCT4 and SOX2. Nature Biotechnology, v. 26, n. 11, p. 1269-1275, 2008.

HUSSEIN, S. M.; BATADA, N. N.; VUORISTO, S.; CHING, R. W.; AUTIO, R.; NÄRVÄ, E.; NG, S.; SOUROUR, M.; HÄMÄLÄINEN, R.; OLSSON, C.; LUNDIN, K.; MIKKOLA, M.; TROKOVIC, R.; PEITZ, M.; BRÜSTLE, O.; BAZETT-JONES, D. P.; ALITALO, K.; LAHESMAA, R.; NAGY, A.; OTONKOSKI, T. Copy number variation and selection during reprogramming to pluripotency. Nature, v. 471, n. 7336, p. 58-62, 2011.

ICHIDA, J. K.; BLANCHARD, J.; LAM, K.; SON, E. Y.; CHUNG, J. E.; EGLI, D.; LOH, K. M.; CARTER, A. C.; DI, GIORGIO, F. P.; KOSZKA, K.; HUANGFU, D.; AKUTSU, H.; LIU, D. R.; RUBIN, L. L.; EGGAN, K. A small-molecule inhibitor of tgf-Beta signaling replaces $S O X 2$ in reprogramming by inducing $N A N O G$. Cell Stem Cell, v. 5, n. 5, p. 491503, 2009.

JAENICH, R.; YOUNG, R. Stem cells, the molecular circuity of Pluripotency and nuclear reprogramming. Cell, v. 132, n. 4, p. 567-82, 2008.

JEWGENOW, K.; PARIS, M. C. J. Preservation of female germ cells from ovaries of cat species. Theriogenology, v. 66, n. 1, p. 93-100, 2006.

JI, G.; RUAN, W.; LIU, K.; WANG, F.; SAKELLARIOU, D.; CHEN, J.; YANG, Y.; OKUKA, M.; HAN J.; LIU, Z.; LAI, L.; GAGOS, S.; XIAO, L.; DENG, H.; LI, N.; LIU, L. Telomere reprogramming and maintenance in porcine iPS cells. Plos One, v. 30, n. 8, p. e74202, 2013.

KIM, J. B.; SEBASTIANO, V.; WU, G.; ARAÚZO-BRAVO, M. J.; SASSE, P.; GENTILE, L.; KO, K.; RUAU, D.; EHRICH, M.; VAN DEN BOOM, D.; MEYER, J.; HUBNER, K.; BERNEMANN, C.; ORTMEIER, C.; ZENKE, M.; FLEISCHMANN, B. K.; ZAEHRES, H.; SCHOLER, H. R. OCT4-Induced Pluripotency in Adult Neural Stem Cells. Cell, v. 136, n. 3, p. 411-419, 2009.

KOH, S.; PIEDRAHITA, J. A. From "ES-like" cells to induced pluripotent stem cells: a historical perspective in domestic animals. Theriogenology, v. 81, n. 1, p. 103-11, 2014.

KOH, S.; THOMAS, R.; TSAI, S.; BISCHOFF, S.; LIM, J. H.; BREEN, M.; OLBY, N. J.; PIEDRAHITA, J. A. Growth Requirements and Chromosomal Instability of Induced Pluripotent Stem Cells Generated from Adult Canine Fibroblasts. Stem Cells and Development, v. 22, n. 6, p. 951-63, 2013.

KUIJK, E. W.; LOPES, S. M. C. S.; GEIJSEN, N.; MACKLON, N.; ROELEN, B. A. J. The Different Shades of Mammalian Pluripotent stem cells. Human Reproduction Update, v. 17, n. 2, p. 254-27, 2010. 
LANGFORD, C. F.; FISCHER, P. E.; BINNS, M. M.; HOLMES, N. G.; CARTER, N. P. Chromosome-specific paints from a high-resolution flow karyotype of the dog. Chromosome Research, v. 4, n. 2, p. 115-23, 1996.

LEE, A. S.; XU, D.; PLEWS, J. R.; NGUYEN, P. K.; NAG, D.; LYONS, J. K.; HAN, L.; HU, S.; LAN, F.; LIU, J.; HUANG, M.; NARSINH, K. H.; LONG, C. T.; DE ALMEIDA, P. E.; LEVI, B.; KOOREMAN, N.; BANGS, C.; PACHARINSAK, C.; IKENO, F.; YEUNG, A. C.; GAMBHIR, S. S.; ROBBINS, R. C.; LONGAKER, M. T.; WU, J. C. Preclinical derivation and imaging of autologously transplanted canine induced pluripotent stem cells. The Journal of Biological Chemistry, v. 286, n. 37, p. 32697-32704, 2011.

LI, H. L.; FUJIMOTO, N.; SASAKAWA, N.; SHIRAI, S.; OHKAME, T.; SAKUMA, T.; TANAKA, M.; AMANO, N.; WATANABE, A.; SAKURAI, H.; YAMAMOTO, T.; YAMANAKA, S.; HOTTA, A. Precise correction of the dystrophin gene in duchenne muscular dystrophy patient induced pluripotent stem cells by TALEN and CRISPR-Cas9. Stem Cell Reports, v. 4, n. 1, p. 143-54, 2015.

LI, Y.; ZHANG, Q.; YIN, X.; YANG, W.; DU, Y.; HOU, P.; GE, J.; LIU, C.; ZHANG, W.; ZHANG, X.; WU, Y.; LI, H.; LIU, K.; WU, C.; SONG, Z.; ZHAO, Y.; SHI, Y.; DENG, H. Generation of iPSCs from mouse fibroblasts with a single gene, OCT4, and small molecules. Cell Research, v. 2, n. 1, p. 196-204, 2011.

LIANG, G.; ZHANG, Y. Embryonic stem cell and induced pluripotent stem cell: an epigenetic perspective. Cell Research, v. 23, n.1, p. 49-69, 2013.

LIN C. H.; JACKSON, A. L.; GUO, J.; LINSLEY, P.; EISENMAN, R. N. A. Myc-regulated microRNAs attenuate embryonic stem cell differentiation The EMBO Journal, v. 28, n. 20, p. 3157-3170, 2009a.

LIN, T.; AMBASUDHAN, R.; YUAN, X.; LI, W.; HILCOVE, S.; ABUJAROUR, R.; LIN, X.; HAHM, H. S.; HAO, E.; HAYEK, A.; DING, S. A chemical platform for improved induction of human iPSCs. Nature Methods, v. 6, n. 11, p. 805-808, $2009 \mathrm{~b}$.

LIU, H.; ZHU, F.; YONG, J.; ZHANG, P.; HOU, P.; LI, H.; JIANG, W.; CAI, J.; LIU, M.; CUI, K.; QU, X.; XIANG, T.; LU, D.; CHI, X.; GAO, G.; JI, W.; DING, M.; DENG, H. Generation of induced pluripotent stem cells from adult rhesus monkey fibroblasts. Cell Stem Cell, v. 3, n. 6, p. 587-90, 2008.

LIVAK, K. J.; SCHMITTGEN, T. D. Analysis of relative gene expression data using realtime quantitative PCR and the 2(-Delta Delta C(T)) Method. Methods, v. 25, n. 4, p. 402-408, 2001.

LUO, J.; SUHR, S. T.; CHANG, E. A.; WANG, K.; ROSS, P. J.; NELSON, L. L.; VENTA, P. J.; KNOTT, J. G.; CIBELLI, J. B. Generation of Leukemia Inhibitory Factor and Basic Fibroblast Growth Factor-Dependent Induced Pluripotent Stem Cells from Canine Adult Somatic Cells. Stem cells and development, v. 20, n. 10, p. 1669-78, 2011. 
LYSSIOTIS, C. A.; FOREMAN, R. K.; STAERK, J.; GARCIA, M.; MATHUR, D.; MARKOULAKI, S.; HANNA, J.; LAIRSON, L. L.; CHARETTE, B. D.; BOUCHEZ, L. C.; BOLLONG, M.; KUNICK, C.; BRINKER, A.; CHO, C. Y.; SCHULTZ, P. G.; JAENISCH, $\mathrm{R}$. Reprogramming of murine fibroblasts to induced pluripotent stem cells with chemical complementation of KLF4. Proceedings of the National Academy of Sciences, v. 106, n. 22, p. 8912-8917, 2009.

MAHERALI, N.; SRIDHARAN, R.; XIE, W.; UTIKAL, J.; EMINLI, S.; ARNOLD, K.; STADTFELD, M.; YACHECHKO, R.; TCHIEU, J.; JAENISCH, R.; PLATH, K.; HOCHEDLINGER, K. Directly reprogrammed fibroblasts show global epigenetic remodeling and widespread tissue contribution. Cell Stem Cell, v. 1, n. 1, p. 55-70, 2007.

MALAVER-ORTEGA, L. F.; SUMER, H.; LIU, J.; VERMA, P. J. The state of the art for pluripotent stem cells derivation in domestic ungulates. Theriogenology, v. 78, n. 8, p. 1749$62,2012$.

MALI, P.; CHOU, B. K.; YEN, J.; YE, Z.; ZOU, J.; DOWEY, S.; BRODSKY, R. A.; OHM, J. E.; YU, W.; BAYLIN, S. B.; YUSA, K.; BRADLEY, A.; MEYERS, D. J.; MUKHERJEE, C.; COLE, P. A.; CHENG, L. Butyrate greatly enhances derivation of human induced pluripotent stem cells by promoting epigenetic remodeling and the expression of pluripotency-associated genes. Stem Cells, v. 28, n. 4, p. 713-720, 2010.

MARSON, A.; FOREMAN, R.; CHEVALIER, B.; BILODEAU, S.; KAHN, M.; YOUNG, R. A.; JAENISCH, R. Wnt signaling promotes reprogramming of somatic cells to pluripotency.

Cell Stem Cell, v. 3, n. 2, p. 132-5, 2008.

MARTIN, G. R. Isolation of a pluripotent cell line from early mouse embryos cultured in medium conditioned by teratocarcinoma stem cells. Proceedings of the National Academy of Sciences, v. 78, n. 12, p. 7634-7638, 1981.

MEISSNER, A. Epigenetic modifications in pluripotent and differentiated cells. Nature Biotechnology, v. 28, n. 10, p. 1079-88, 2010.

MIGLINO, M. A.; AMBRÓSIO, C. E.; MARTINS, D. S.; WENCESLAU, C. V.; PFARRER, C.; LEISER, R. The carnivore pregnancy: The development of the embryo and fetal membranes. Theriogenology, v. 66, n. 6-7, p. 1699-1702, 2006.

MIKKELSEN, T. S.; HANNA, J.; ZHANG, X.; KU, M.; WERNIG, M.; SCHORDERET, P.; BERNSTEIN, B. E.; JAENISCH, R.; LANDER, E. S.; MEISSNER, A. Dissecting direct reprogramming through integrative genomic analysis. Nature, v. 454, n. 7200, p. 49-55, 2008.

MITALIPOV, S.; WOLF, D. Totipotency, pluripotency and nuclear reprogramming. Advances in Biochemical Engineering, Biotechnology, v. 114, p. 185-99, 2009.

MITSUI, K.; TOKUZAWA, Y.; ITOH, H.; SEGAWA, K.; MURAKAMI, M.; TAKAHASHI, K.; MARUYAMA, M.; MAEDA, M.; YAMANAKA S. The Homeoprotein $N A N O G$ Is Required For maintenance of pluripotency in mouse epiblast and ES cells. Cell, v. 113, n. 5, p. 631-642, 2003. 
MONTINI, E.; CESANA, D.; SCHMIDT, M.; SANVITO, F.; PONZONI, M.; BARTHOLOMAE, C.; SERGI, S. L.; BENEDICENTI, F.; AMBROSI, A.; DI SERIO, C.; DOGLIONI, C.; KALLE, C. V.; NALDINI, L. Hematopoietic stem cell gene transfer in a tumor-prone mouse model uncovers low genotoxicity of lentiviral vector integration. Nature Biotechnology, v. 24, n. 6, p. $687-696,2006$.

NAGY, K.; SUNG, H. K.; ZHANG, P.; LAFLAMME, S.; VINCENT, P.; AGHAMOHAMMADI, S.; WOLTJEN, K.; MONETTI, C.; MICHAEL, I. P.; SMITH, L. C.; NAGY, A. Induced pluripotent stem cell lines derived from equine fibroblasts. Stem Cell Reviews, v. 7, n. 3, p 693-702, 2011.

NAKAGAWA, M.; KOYANAGI, M.; TANABE, K.; TAKAHASHI, K.; ICHISAKA, T.; AOI, T.; OKITA, K.; MOCHIDUKI, Y.; TAKIZAWA, N.; YAMANAKA, S. Generation Of Induced pluripotent stem cells without Myc from mouse and human fibroblasts. Nature Biotechnology, v. 26, n. 1, p. 101-106, 2008.

NARDI, N. B.; MEIRELLES, L. S. Mesenchymal stem cells : isolation, in vitro expansion and characterization. Handbook of Experimental Pharmacology, v. 2006, n. 174, p. 249$282,2006$.

NICHOLS, J.; ZEVNIK, B.; ANASTASSIADIS, K.; NIWA, H.; KLEWE-NEBENIUS, D.; CHAMBERS, I.; SCHOLER, H.; SMITH, A. Formation of pluripotent stem cells in the mammalian embryo depends on the POU transcription factor OCT4. Cell, v. 95, n. 3, p. 379391, 1998.

NIE, Z.; HU, G.; WEI, G.; CUI, K.; YAMANE, A.; RESCH, W.; WANG, R; GRENN, D. TESSAROLLO, L.; CASELLAS, R.; ZHAO, K.; LEVENS, D. $c-M Y C$ is a universal amplifier of expressed genes in lymphocytes and embryonic stem cells. Cell, v. 151, p. 68-79, 2012.

NISHIMURA, K.; TAKAHASHI, J. Therapeutic application of stem cell technology toward the treatment of Parkinson's disease. Biological and Pharmaceutical Bulletin, v. 36, n. 2, p. 171-5, 2013.

NOWAK-IMIALEK, M.; KUES, W.; CARNWATH, J. W.; NIEMANN, H. Pluripotent stem cells and reprogrammed cells in farm animals. Microsc Microanal, v. 17, n. 4, p. 474-497, 2011.

ODORICO, J. S.; KAUFMAN, D. S.; THOMSON, J. A. Multilineage differentiation from human embryonic stem cell lines. Stem Cells, v. 19, n. 3, p. 193-2014, 2001.

OKITA, K.; ICHISAKA, T.; YAMANAKA, S. Generation of germline-competent induced pluripotent stem cells. Nature, v. 448, n. 7151, p. 313-7, 2007.

OKITA, K.; MATSUMURA, Y.; SATO, Y.; OKADA, A.; MORIZANE, A.; OKAMOTO, S.; HONG, H.; NAKAGAYA, M.; TANABE, K.; TEKUSA, K.; TOSHIYUKI, S.;

KUNISADA, T.; TAKAHASHI, M.; TAKAHASHI, J.; SAJI, H.; YAMANAKA, S. A more efficient method to generate integration-free human iPS cells. Nature Methods, v. 8, p. 409$12,2011$. 
OKITA, K.; NAKAGAWA, M.; HYENJONG, H.; ICHISAKA, T.; YAMANAKA, S. Generation of mouse induced pluripotent stem cells without viral vectors. Science, v. 322, n. 5903, p. 949-953, 2008.

OLIVEIRA, C.S.; DE SOUZA, M.M.; SARAIVA, N.Z.; TETZNER, T.A.; LIMA, M.R.; LOPES, F.L.; GARCIA, J.M. In vitro culture of bovine embryos in murine ES cell conditioned media negatively affects expression of pluripotency-related markers OCT4, SOX2 and SSEA1. Reproduction in Domestic Animals, v. 47, n. 3, p. 428-35, 2012.

PAPAPETROU, E. P.; TOMISHIMA, M. J.; CHAMBERS, S. M.; MICA, Y.; REED, E.; MENON, J.; TABAR, V.; MO, Q.; STUDER, L.; SADELIN, M. Stoichiometric and temporal requirements of $O C T 4, S O X 2, K L F 4$, and $c-M Y C$ expression for efficient human iPSC induction and differentiation. Proceedings of the National Academy of Sciences, v. 106, p. 12759-12764, 2009.

PARK, I. H.; ZHAO, R.; WEST, J. A.; YABUUCHI, A.; HUO, H.; INCE, T. A.; LEROU, P. H.; LENSCH, M. W.; DALEY, G. Q. Reprogramming of human somatic cells to pluripotency with defined factors. Nature, v. 451, n. 7175, p. 141-6, 2008.

PATTERSON, D. F. Companion animal medicine in the age of medical genetics. Journal of Veterinary Internal Medicine, v. 14, n. 1, p. 1-9, 2000.

PIEDRAHITA JA, ANDERSON GB, BONDURANT RH: 1990. On the Isolation of Embryonic Stem Cells: Comparative Behavior of Murine, Porcine and Ovine Embryos. Theriogenology, v. 34, n. 5, p. 879-901, 1990b.

PIEDRAHITA, J. A.; ANDERSON, G. B.; BONDURANT, R. H. Influence of feeder layer type on the efficiency of isolation of porcine embryo-derived cell lines. Theriogenology, $\mathrm{v}$. 34, n. 5, p. 865-77, 1990a.

POORMAN, K.; BORST, L.; MOROFF, S.; ROY, S.; LABELLE, P.; MOTSINGER-REIF, A.; BREEN, M. Comparative cytogenetic characterization of primary canine melanocytic lesions using array CGH and fluorescence in situ hybridization. Chromosome Research, v. 23, n. 2, p. 171-86, 2015.

POPP, C.; DEAN, W.; FENG, S.; COKUS, S. J.; ANDREWS, S.; PELLEGRINI, M.;

JACOBSEN, S. E.; REIK W. Genome-wide erasure of DNA methylation in mouse primordial germ cells is affected by AID deficiency. Nature, v. 463, p. 1101-1105, 2010.

REIK, W.; DEAN, W.; WALTER, J. Epigenetic reprogramming in mammalian development. Science, v. 293, n. 5532, p. 1089-93, 2001

REIMANN-BERG, N.; BULLERDIEK, J.; MURUA ESCOBAR, H.; NOLTE, I. Chromosome analyses in dogs. Tierärztliche Praxis Kleintiere, v. 40, n. 3, p. 191-6, 2012.

RIZZINO, A. Concise review: the SOX2-OCT4 connection: critical players in a much larger interdependent network integrated at multiple levels. Stem Cells, v. 31, p. 1033-1039, 2013. 
RIZZINO, A. SOX2 and Oct-3/4: a versatile pair of master regulators that orchestrate the selfrenewal and pluripotency of embryonic stem cells by functioning as molecular rheostats.

Wiley Interdisciplinar Reviews: Systems Biology and Medicine, v. 1, n. 2, p. 228-236, 2009.

RUVINSKY A. Basics of gametic imprinting. Journal of Animal Science, v. 77, n. 2, p. 228-37, 1999.

SAITO S, UGAI H, SAWAI K, YAMAMOTO Y, MINAMIHASHI A, KUROSAKA K. Isolation of embryonic stem-like cells from equine blastocysts and their differentiation in vitro. FEBS Letters, v. 531, n. 3, p. 389-96, 2002.

SCHLAEGER, T. M.; DAHERON, L.; BRICKLER, T. R.; ENTWISLE, S.; CHAN K, C. A.; DEVINE, A.; ETTENGER, A.; FITZGERALD, K.; GODFREY, M.; GUPTA, D.;

MCPHERSON, J.; MALWADKAR, P.; GUPTA, M.; BELL, B.; DOI, A.; JUNG, N.; LI, X.; LYNES, M. S.; BROOKES, E.; CHERRY, A. B.; DEMIRBAS, D.; TSANKOV, A. M.; ZON, L. I.; RUBIN, L. L.; FEINBERG, A. P.; MEISSNER, A.; COWAN, C. A.; DALEY, G. Q. A comparison of non-integrating reprogramming methods. Nature Biotechnology, v. 33, n. 1, p. 58-63, 2014.

SCHNEIDER, M. R.; ADLER, H.; BRAUN, J.; KIENZLE, B.; WOLF, E.; KOLB, H. J. Canine embryo-derived stem cells - toward clinically relevant animal models for evaluating efficacy and safety of cell therapies. Stem Cells, v. 25, n. 7, p. 1850-1, 2007.

SCHNEIDER, M. R.; WOLF, E.; BRAUN, J.; KOLB, H. J.; ADLER, H. Embryonic Stem Cells in Domestic Animals Canine embryonic stem cells: State of the art. Theriogenology, v. 74, n. 4, p. 492-497, 2010.

SHAPIRO, S. G.; RAGHUNATH, S.; WILLIAMS, C.; MOTSINGER-REIF, A. A.; CULLEN, J. M.; LIU, T.; ALBERTSON, D.; RUVOLO, M.; BERGSTROM LUCAS, A.; JIN, J.; KNAPP, D. W.; SCHIFFMAN, J. D.; BREEN, M. Canine urothelial carcinoma: genomically aberrant and comparatively relevant. Chromosome Research, v. 23, n. 2, p. 311-31, 2015.

SHIMADA, H.; NAKADA, A.; HASHIMOTO, Y.; SHIGENO, K.; SHIONOYA, Y.; NAKAMURA, T.; Generation of canine-induced pluripotent stem cells by retroviral transduction and chemical inhibitors. Molecular Reproduction and Development, v. 77, n. 2, p. 2, 2010.

SILVA, J.; BARRANDON, O.; NICHOLS, J.; KAWAGUCHI, J.; THEUNISSEN, T. W.; SMITH, A. Promotion of reprogramming to ground state pluripotency by signal inhibition. PLoS Biology, v. 6, n. 10, p. 253, 2008.

SIMARA, P.; MOTL, J. A.; KAUFMAN, D. S. Pluripotent stem cells and gene therapy. Translational Research, v. 161, n. 4, p. 284-92, 2013.

SOMMER, C. A.; STADTFELD, M.; MURPHY, G. J.; HOCHEDLINGER, K.; KOTTON, D. N.; MOSTOSLAVSKY, G. Induced Pluripontent Stem Cell Generation Using a single lentiviral stem cell cassette. Stem Cells, v. 27, n. 3, p. 543-549, 2009. 
STADTFELD, M.; NAGAYA, M.; UTIKAL, J.; WEIR, G.; HOCHEDLINGER, K. Induced pluripotent stem cells generated without viral integration. Science, v. 322, p. 945-9, 2008.

STEICHEN, C.; MALUENDA, J.; TOSCA, L.; LUCE, E.; PINEAU, D.; DIANAT, N.; HANNOUN, Z.; TACHDJIAN, G.; MELKI, J.; DUBART-KUPPERSCHMITT, A. An atypical human induced pluripotent stem cell line with a complex, stable, and balanced genomic rearrangement including a large de novo 1q uniparental disomy. Stem Cells Translational Medecine, v. 4, n. 3, p. 224-9, 2015.

SUMER, H.; LIU, J.; MALAVER ORTEGA, L. F.; LIM, M. L.; KHODADADI, K.; VERMA, P. J. NANOG is a key factor for induction of pluripotency in bovine adult fibroblasts. Journal of Animal Science, v. 89, n. 9, p. 2708-16, 2011.

SWITOŃSKI, M.; REIMANN, N.; BOSMA, A. A.; LONG, S.; BARTNITZKE, S.; PIEŃKOWSKA, A.; MORENO-MILAN, M. M.; FISCHER, P. Report on the progress of standardization of the G-banded canine (Canis familiaris) karyotype. Committee for the Standardized Karyotype of the Dog (Canis familiaris). Chromosome Research, v. 4, n. 4, p. 306-9, 1996.

SWITONSKI, M.; SZCZERBAL, I.; NOWACKA, J. The dog genome map and its use in mammalian comparative genomics. Journal of Applied Genetics, v. 45, n. 2, p. 195-214, 2004.

TAKAHASHI, K.; TANABE, K.; OHNUKI, M.; ICHISAKA, T.; TOMODA, K.; YAMANAKA, S. Induction of pluripotent stem cells from adult human fibroblasts by defined factors. Cell, v. 131, n. 5, p. 861-72, 2007.

TAKAHASHI, K.; YAMANAKA, S. Induction of pluripotent stem cells from mouse embryonic and adult fibroblast cultures by defined factors. Cell, v. 126, n. 4, p. 663-76, 2006.

TELUGU, B. P.; EZASHI, T.; ROBERTS, R. M. The promise of stem cell research in pigs and other ungulate species. Stem Cell Reviews, v. 6, n. 1, p. 31-41, 2010.

TERAI, M.; IZUMIYAMA-SHIMOMURA, N.; AIDA, J.; ISHIKAWA, N.; KUROIWA, M.; POON, S. S.; ARAI, T.; TOYODA, M.; AKUTSU, H.; UMEZAWA, A.; NAKAMURA, K.; TAKUBO, K. Investigation of telomere length dynamics in induced pluripotent stem cells using quantitative fluorescence in situ hybridization. Tissue Cell, v. 45, n. 6, p. 407-13, 2013.

THOMAS, K. R.; CAPECCHI, M. R. Site-directed mutagenesis by gene targeting in mouse embryo-derived stem cells. Cell, v. 51, n. 3, p. 503-12, 1987.

THOMPSON, L. H.; BJORKLUND, A. Reconstruction of brain circuitry by neural transplants generated from pluripotent stem cells. Neurobiology of Disease, v. 79, p. 28-40, 2015.

THOMSON, J. A.; ITSKOVITZ-ELDOR, J.; SHAPIRO, S. S.; WAKNITZ, M. A.; SWIERGIEL, J. J.; MARSHALL, V. S.; JONES, J. M. Embryonic stem cell lines derived from human blastocysts. Science, v. 282, n. 5391, p. 1145-7, 1998. 
THOMSON, J. A.; KALISHMAN, J.; GOLOS, T. G.; DURNING, M.; HARRIS, C. P.; BECKER, R. A.; HEARN, J. P. Isolation of a primate embryonic stem cell line. Proceedings of the National Academy of Sciences, v. 92, n. 17, p. 7844-7848, 1995.

TRAVIS, A. J.; KIM, Y.; MEYERS-WALLEN, V. Development of new stem cell-based technologies for carnivore reproduction research. Reproduction in Domestic Animals, v. 44, n. 2, p. 22-28, 2009.

TROUNSON, A. Rats, cats, and elephants, but still no unicorn: induced pluripotent stem cells from new species. Cell Stem Cell Previews, v. 4, n. 1, p. 3-4, 2009.

URANIO, F. M.; DELL'AQUILA, M. E.; CAIRA, M.; GUARICCI, A. C.; VENTURA, M.; CATACCHIO, C. R.; MARTINO, N. A.; VALENTINI, L. Characterization and in vitro differentiation potency of early-passage canine amnion and umbilical cord-derived mesenchymal stem cells as related to gestational age. Molecular Reproduction and Development, v. 81, n. 6, p. 539-51, 2014.

URANIO, M. F.; VALENTINI, L.; LANGE-CONSIGLIO, A.; CAIRA, M.; GUARICCI, A. C.; L'ABBATE, A.; CATACCHIO, C. R.; VENTURA, M.; CREMONESI, F.;

DELL'AQUILA, M. E. Isolation, Proliferation, Cytogenetic, and Molecular Characterization and In vitro Differentiation Potency of Canine Stem Cells from Foetal Adnexa: A Comparative Study of Amniotic Fluid, Amnion, and Umbilical Cord Matrix. Molecular Reproduction \& Development, v. 78, n. 5, p. 361-373, 2011.

VAAGS, A. K.; ROSIC-KABLAR, S.; GARTLEY, C. J.; ZHENG, Y. Z.; CHESNEY, A.; VILLAGOMEZ, D. A. Derivation and characterization of canine embryonic stem cell lines with in vitro and in vivo differentiation potential. Stem Cells, v. 27, n. 2, p. 329-40, 2009.

VASKOVA, E. A.; STEKLENEVA, A. E.; MEDVEDEV, S. P.; ZAKIAN, S. M. "Epigenetic memory" phenomenon in induced pluripotent stem cells. Acta Naturae, v. 5, n. 4, p. 15-21, 2013.

VERFAILLIE, C. M.; PERA, M. F.; LANSDORP, P. M. Stem cells: hype and reality. Hematology, v. 2000, p. 369-91, 2002.

VERMA, R.; HOLLAND, M. K.; TEMPLE-SMITHA, P.; VERMA, P. J. Inducing pluripotency in somatic cells from the snow leopard (Panthera uncia), an endangered felid. Theriogenology, v. 77, p. 220-228, 2012.

WAKITANI, S.; TAKAOKA, K.; HATTORI, T.; MIYAZAWA, N.; IWANAGA, T.; TAKEDA, S.; WATANABE, T. K.; TANIGAMI, A. Embryonic stem cells injected into the mouse knee joint form teratomas and subsequently destroy the joint. Rheumatology (Oxford), v. 42, n. 1, p. 162-5, 2003.

WANG, Q.; XU, X.; LI, J.; LIU, J.; GU, H.; ZHANG, R.; CHEN, J.; KUANG, Y.; FEI, J.; JIANG, C.; WANG, P.; PEI, D.; DING, S.; XIE, X. Lithium, an anti-psychotic drug, greatly enhances the generation of induced pluripotent stem cells. Cell Research, v. 21, n.10, p. 1424-1435, 2011. 
WARREN, L.; MANOS, P. D.; AHFELDT, T.; LOH, Y. H.; LI, H.; LAU, F.; EBINA, W.; MANDAL, P. K.; SMITH, Z. D.; MEISSNER, A.; DALEY, G. Q.; BRACK, A. S.; COLLINS, J. J.; COWAN, C.; SCHLAEGER, T. M.; ROSSI, D. J. Highly efficient reprogramming to pluripotency and directed differentiation of human cells with synthetic modified mRNA. Cell Stem Cell, v. 7, p. 618-630, 2010.

WASYLISHEN, A. R.; PENN, L. Z. Myc: the beauty and the beast. Genes Cancer, v. 1, p. 532-541. 2010.

WHITWORTH, D. J.; OVCHINNIKOV, D. A.; WOLVETANG, E. J. Generation and characterization of LIF-dependent canine induced pluripotent stem cells from adult dermal fibroblasts. Stem Cells and Development, v. 21, n. 12, p. 2288-97, 2012.

WILCOX, J. T.; SEMPLE, E.; GARTLEY, C.; BRISSON, B. A.; PERRAULT, S. D.; VILLAGOMEZ, D. A. Characterization of canine embryonic stem cell lines derived from different niche microenvironments. Stem Cells Development, v. 18, n. 8, p. 1167-78, 2009.

YAMAGUCHI, S.; HIRANO, K.; NAGATA, S.; TADA, T. SOX2 expression effects on direct reprogramming efficiency as determined by alternative somatic cell fate. Stem Cell Research, v.6, n.177, p. 177-186, 2011.

YAMANAKA, S. Pluripotency and nuclear reprogramming. Philosophical Transactions of the Royal Society of London B: Biological Science, v. 363, n. 1500, p. 2079-87, 2008.

YAMANAKA, S. Strategies and new developments in the generation of patientspecific pluripotent stem cells. Cell Stem Cell, v. 1, n. 1, p. 39-49, 2007.

YU, J.; HU, K.; SMUGA-OTTO, K.; TIAN, S.; STEWART, R.; SLUKVIN, L. I.; THOMSON, J. A. Human induced pluripotent stem cells free of vector and transgene sequences. Science, v. 324, n. 5928, p. 797-801, 2009.

YU, X.; JIN, G.; YIN, X.; CHO, S.; JEON, J.; LEE, S.; KONG, I. Isolation and characterization of embryonic stem-like cells derived from in vivo-produced cat blastocysts. Molecular Reproduction and Development, v. 75, n. 9, p. 1426-32, 2008.

ZHU, S.; LI, W.; ZHOU, H.; WEI, W.; AMBASUDHAN, R.; LIN, T.; KIM, J.; ZHANG, K.; DING, S. Reprogramming of human primary somatic cells by OCT4 and chemical compounds. Cell Stem Cell, v. 7, n. 6, p. 651-655, 2010. 


\title{
Reproduction in Domestic Animals
}

Reprod Dom Anim 49 (Suppl. 4), 2-10 (2014); doi: 10.1111/rda.12392

ISSN 0936-6768

\section{Review Article}

\section{Stem Cells and Regenerative Medicine in Domestic and Companion Animals: A Multispecies Perspective}

\author{
NN Gonçalves ${ }^{1,2}$, CE Ambrósio ${ }^{1,2}$ and JA Piedrahita ${ }^{3,4}$ \\ ${ }^{1}$ Department of Veterinary Medicine, Faculty of Animal Science and Food Engineering, FZEA/USP, Pirassununga, Sao Paulo, Brazil, ${ }^{2}$ Department \\ of Surgery, Faculty of Veterinary Medicine and Animal Science, FMVZ/USP, Sao Paulo, Brazil, ${ }^{3}$ Department of Molecular Biomedical Sciences, \\ College of Veterinary Medicine, North Carolina State University, Raleigh, NC, USA; ${ }^{4}$ Center for Comparative Medicine and Translational \\ Research, North Carolina State University, Raleigh, NC, USA
}

\section{Contents}

Since their original isolation, the majority of the work on embryonic stem cells (ESC) has been carried out in mice. While the mouse is an outstanding model for basic research, it also has considerable limitations for translational work, especially in the area of regenerative medicine. This is due to a combination of factors that include physiological and size differences when compared to humans. In contrast, domestic animal species, such as swine, and companion animal species, such as dogs, provide unique opportunities to develop regenerative medicine protocols that can then be utilized in humans. Unfortunately, at present, the state of knowledge related to, and availability of, ESC from domestic animals vary among species such as pig, horse, dog and cat, and without exception lags significantly behind the mouse and human. It is clear that much still needs to be discovered. The 'stem cell-like' cell lines being reported are still not satisfactorily used in regenerative medicine, due to reasons such as heterogeneity and chromosomal instability. As a result, investigators have searched for alternate source of cells that can be used for regenerative medicine. This approach has uncovered a range of adult stem cells and adult progenitor cells that have utility in both human and veterinary medicine. Here, we review a range of stem cells, from ESC to induced pluripotent stem cells, and discuss theit potential application in the field of regenerative medicine.

\section{Introduction}

Pluripotent stem cells are defined by their ability to indefinitely self-renew, while maintaining the capacity to differentiate into any cell type, and can also be maintained indefinitely in culture and yet maintain competence to produce all the cells within a foetus. (Brevini et al. 2007; Kuijik et al. 2010). In general, they can range from totipotent stem cells that are able to generate a complete organism, including extra-embryonic membranes, to unipotent stem cells such as muscle progenitor cells that are able to differentiate into just one cel type (Mitalipov and Wolf 2009; Malaver-Ortega et al 2012; Simara et al. 2013; Zheng et al. 2014). Embryonic stem cells (ESC), in particular, have been extensively studied.

The establishment of ESC lines from explant cultures of the inner cell mass (ICM) obtained from in vivoderived mouse $(\mathrm{m})$ blastocysts was first reported over 31 years ago in mice (Evans and Kaufman 1981; Martin 1981), followed by non-human primates (Thomson et al. 1995) and humans (Thomson et al. 1998; Reubinoff et al. 2000). Embryonic stem cells are isolated from the ICM of developing embryos and are capable of differentiating into derivatives of all three embryonic germ layers: ectoderm, endoderm and mesoderm. This is most evident when they are injected into a developing blastocyst-stage embryo for development of a chimeric animal. Essentially, all organs of these chimeric animals, including the germ cells, are composed of a mixture of ESC-derived cell and host blastocyst cells.

Unfortunately, establishing stable domestic animal embryonic cells remains an issue; thus, the use of reprogrammed somatic cells offers an excellent alternative. Induced pluripotent stem cells or iPSC were initially developed by Takahashi and Yamanaka (2006). In their seminal work, they demonstrated that induced expression of four key transcription factors, $O C T 4, S O X 2, K L F 4$ and $C-M Y C$ (Yamanaka factors or OSKM), was capable of reprogramming mouse somatic cells into cells with similar pluripotential characteristics to ESC cells. Since then, many efforts have been made to obtain and characterize iPSC cells in domestic animals (for review, please see Koh and Piedrahita 2014).

An alternate source of pluripotent stem cells are those derived from primordial germ cell (PGCs). PGC-derived pluripotent cell lines are referred to as EGC cells. Essentially, they have the same characteristics as ESC cells and have been used to generate germ line chimeras in mice (Lawson et al. 1999). Both ES and EG cells express a series of transcription factors to maintain the pluripotent state. These include OCT4 (POU domain protein - Pou5f1) and NANOG (Homeobox protein) (Rizzino 2013). ESC and EGC, share some unique characteristics that help define them as pluripotent stem cells. These include positive enzymatic activities for alkaline phosphatase and telomerase, and expression of 'stemness' genes including OCT4 and NANOG. Developmentally, they have the ability to contribute to the germline of chimeric animals and to form teratomas when injected into nude mice. In the past, when a cell line failed to satisfy any of these requirements, they were defined as 'stem cell-like' [see Koh and Piedrahita (2014) for review in this area]. While our knowledge of ESC and EGC cells in mice is extensive, the same cannot be said for our understanding of the biology of ESC cell and EGC cells in domestic animals.

At present, it is accepted that mouse and human ESC cells differ both morphologically and developmentally. Mouse ESC cells are LIF-dependent, have a compacted 
multilayer appearance, can be passaged by trypsinization methods and form germ line chimeras when injected into a blastocysts. In contrast, human ESC cells are FGF2-dependent, form epithelial-like monolayers, are trypsin-sensitive (mechanical passage is generally used) and have reduced developmental competence when compared to mouse ESC cells. It is now known that this is due to a later embryonic origin for the human ESC cells. To differentiate between the two, the term EpiSCs is used to indicate a later development origin, FGF2 dependency and sensitivity to single cell cloning (see Nichols and Smith 2011 for review of this topic).

\section{Domestic Animals: Advances in the Isolation of Embryonic-Like Stem Cells}

Availability of ESC cells in domestic and companion species has been an intensive area of interest for the last 30 years. Initially, this research focused on isolating ESC cells with the goal of using them for genetic modifications, as had been accomplished successfully in mice (Evans and Kaufman 1981). In mice, the availability of ESC cells allowed the development of complex genetic manipulation technologies such as gene targeting by homologous recombination. This work was recognized with the Nobel Prize (Evans and Kaufman 1981; Doetschman et al. 1987; Thomas and Capecchi 1987). More recently, however, the focus shifted from one of using ESC cells for genetic modifications to using ESC cells for regenerative medicine (Cibelli et al. 2013).

A large number of reviews have been written covering the topic of ESC cells in domestic animals (Travis et al. 2009; Wilcox et al. 2009; Blomberg and Telugu 2012; Galdolfi et al. 2012; Malaver-Ortega et al. 2012; Nowak-Imialek and Niemann 2012). Combined, these reviews clarify and increase our knowledge about ESC in domestic animals, however, they essentially summarize that, at this point, we have a wide range of cell lines, with differing differentiation and proliferation properties, but few if any have passed all the requirements of a true ESC (Koh and Piedrahita 2014).

The earliest efforts made to derive embryo-derived cell lines from non-laboratory animals include the work of Evans et al. (1990) who first described pluripotent cells from porcine and bovine embryos. Several porcine lines were generated when blastocyst-stage embryos were cultured on mouse STO (a transformed foetal fibroblast line) feeder layers. The cell lines were poorly characterized, yet they were capable of spontaneously differentiating into derivatives of tree germ layers when cultured at high density. The results of Piedrahita et al. (1990a) were not as optimistic and suggested that growth of porcine and ovine ES cells was more complex than that of mice. While multiple cell lines were isolated, the cell lines had a limited capacity to differentiate and were incapable of chimera generation. Similarly, Piedrahita et al. (1990b), reported the effects of different feeder layers on porcine ES-like cells, such as Buffalo rat liver cells (BRL), continuous cell line of murine embryonic fibroblasts (STO), porcine embryonic fibroblasts (PEF), murine embryonic fibroblasts (MEF), porcine uterine epithelial cells (PUE), epithelial-like porcine embryo- derived cell line ( $\mathrm{PH} 3 \mathrm{~A})$ and the combinations of these feeders. None of the feeders tested provided optimal conditions for isolation of porcine ES-like cells. Amazingly, while there have been multiple and extensive reports on the isolation of porcine ES-like cells (reviewed in Brevini et al. 2010 and Malaver-Ortega et al. 2012), 24 years after these initial reports we still do not have any porcine stem cells of blastocyst origin that have conclusively shown all the hallmarks of true ES cells, including chimera generation.

In the bovine, a recent review describes efforts in this area over the last 25 years, moving from the isolation of ES-like cells that could be maintained just for a few passages, and showed chromosomal abnormalities (Strelchenko et al. 1991, 1995) to the most recent work reporting isolation of putative ES cells that express known markers of pluripotency such as SSEA-1, OCT4, SSEA-4 and NANOG and the ability to generate teratomas when injected into nude mice. Like, the porcine, however, there is still no description of cell lines that can generate germ line chimeras (reviewed by Malaver-Ortega et al. 2012).

In cats, the first report of ES-like cell isolation date from 2008 when Yu et al. isolated ES-like cells from the ICM of in vivo generated embryos cultured on cat embryonic fibroblast feeder layers. These cells showed typical stem cell morphology, where positive for alkaline phosphatase and pluripotency markers, formed embryoid bodies and were capable, in vitro, to differentiate into myocardiocytes. However, none of the cell lines isolated could proliferate long-term in an undifferentiated state. A second study on cat ESC cells (Gómez et al. 2010) reported the generation of cat embryonic stem-like cells from blastocysts produced in vitro. The cell lines were cultured in feeder layer from cat dermal or mouse embryonic fibroblasts, with the cat feeder layer increasing the number of cell lines when compared to heterologous feeders (mouse feeder layer). The isolated lines were maintained for 9-12 passages, expressed the pluripotency marker alkaline phosphatase, and were capable of spontaneous differentiation and forming embryoid bodies. Unfortunately, the characterization did not include teratoma formation or chimera generation. Thus, true cat ESC cells have not been reported.

In equids, the horse shows promise for clinical studies and it is now an accepted model for cartilage and tendon repair as it mimics the human athlete. Saito et al. (2002) described equine ESC-like cells with a normal karyotype isolated from frozen and thawed blastocysts cultured on umbilical cord-derived bovine fibroblasts feeder layers. These lines expressed pluripotency markers, alkaline phosphatase activity and the capacity for differentiating in vitro to neural progenitor cells and to endothelial or hematopoietic lineages. The cells grew for over 56 passages with most characterization occurring prior to passage 17th. Of interest is the use of umbilical cordderived fibroblasts as feeders, as it is now known that this tissue is an excellent source of pluripotent mesenchymal stem cells (MSCs) (El Omar et al. 2014). In essence, Saito et al. cultured one type of stem cell using another type of stem cell, also capable of differentiation into multiple tissue types and prolonged proliferation, as a feeder layer. 
More recently, Li et al. (2006) and Guest and Allen (2007) established horse ESC-like cells from ICM and cultured for 50 passages. Morphology of the cells showed a typical epithelia-like morphology typical of human ESC cells (EpiSC) cultured in FGF-containing media. While the cells were capable of differentiating into all three germ layers, neither did they for teratomas when injected into nude mice nor were they tested for chimera generation. These cells, however, have now been tested in an allogeneic model of damaged tendon, and the authors report that the horse ESC were able to survive up to 90 days at the injected site without any evidence of immune rejection. However, a significant number of questions remain unanswered due to differences in labelling methods, the lack of controls and the limited quality of the images presented (Guest et al. 2010).

Of all companion animal species, the dog is perhaps the one of greatest interest in regenerative medicine. This is because the dog suffers from a large number of naturally arising inherited diseases that mimic those seen in humans (Patterson 2000; Switonski et al. 2004). In addition, there is increased interest in the application of cell-based therapies to this species in veterinary medicine. Therefore, there is both a veterinary and a human medicine interest. In dogs, there have been several reports of dog ESC. Hatoya et al. (2006), collected canine embryos at different stages (morulae, blastocyst and hatched blastocyst) and plated either the inner part of the morulae or the ICM on LIF-based media on mouse feeder layer. No cell lines were obtained from morulae, but several were established from the blastocysts. The colonies showed typical EpiSC-like morphology, were sensitive to single cell dissociation and responded better to mechanical passage. They also expressed pluripotency markers, formed embryo bodies and differentiated into neurons, myocardium, epithelium and melanocyte-like cells. Schneider et al. (2007) performed similar studies and reported isolation of ESC-like cell lines in LIF-based media. Cell line markers and differentiation ability were similar to those reported by Hatoya et al. (2006). Hayes et al. (2008) also using LIF-based media reported isolation and maintenance of an ESC-like cell line for 34 passages. The cell line had the typical epithelial morphology characteristic of EpiSC and, in addition, was sensitive to single cell dissociation. However, it was capable of multilineage differentiation and expressed both proteins and mirRNAs indicative of pluripotency. Wilcox et al. (2009) were the first to report culture of canine ES-like cell in both LIF and FGF. Their results showed that cells rapidly differentiated in the absence of LIF, that cell lines with the ability to differentiate into all three germ layer could be derived, but that their ability to generate teratomas when injected into nude mice was still compromised. More recently, Vaags et al. (2009) isolated ESC cells from canine blastocysts using both LIF and FGF in their culture system. The cell lines expressed all the markers unique to pluripotent stem cells, and morphologically the cell lines formed compacted multilayered colonies similar to mouse ESC cells. More importantly, the cell lines could be maintained for extended passages and generated complex teratomas after injection into nude mice. Thus, with the exception of chimera generation, these cell lines show all the hallmarks of true ESC cells. This work represents a step forward for the complete characterization for dog ESC and the beginning for therapies in large animal models.

Overall, the field of embryonic stem cell isolation and characterization is a complex one with many different approaches for isolation and maintenance being tried, and with a wide range of rigour in how the resulting lines are analysed. This makes it very difficult to determine just what the state-of-the-art approach is for any given species at this time. Below, we have simply summarized some of the observations that have been reported for several species but they are not comprehensive by any means.

\section{Adult Stem Cells}

Due to the difficulties in establishing true stable ESC in most of the species described in Table 1, investigators have turned to other sources of stem cells as sources of material for regenerative medicine: adult stem cells. Of all adult stem cells available, bone marrow (BM-MSC) and adipose derived (ADSC) MSCs are the most commonly used. MSCs, represent a population of stem cells with more restricted differentiation potential compared to ESCs, but they have the advantage that they are easily isolated and maintained in culture (Reviewed by Hipp and Atala 2008). Minimal criteria set by the International Society of Cellular Therapy require that MSCs be positive for CD70, CD90, and CD105 and negative for CD34 (Reviewed by $\mathrm{Lin}$ et al. 2013). However, it is now accepted that MSCs are a highly heterogeneous population of cells that include in some cases CD 34 positive cells. As a result, new markers that better define the stemness of cells are being proposed. This includes some used in the ESC field such as SSEA-4, and others, such as Stro-1, CD271, and CD146 (Feng-Juan et al. 2014). Thus, this field, like the ESC field, is complicated by the wide range of markers investigators use to define their cells. This makes interpretation, comparison and replication of data difficult. Standardization and continuous re-evaluation of MSC markers for clinical applications are needed.

In domestic and companion animals there is a large number of publications and reviews, so in this

Table 1. Similarities and differences between embryonic-like stem cell from dog, cat, pig and horse and embryonic stem cell from mouse

\begin{tabular}{lllcll}
\hline Feature & $\begin{array}{c}\text { Mouse } \\
\text { ESC }^{4}\end{array}$ & $\begin{array}{c}\text { Dog } \\
\text { ELSC }^{b}\end{array}$ & $\begin{array}{c}\text { Cat } \\
\text { ELSC }^{c}\end{array}$ & $\begin{array}{c}\text { Pig } \\
\text { ELSC }^{d}\end{array}$ & $\begin{array}{c}\text { Horse } \\
\text { ELSC }^{e}\end{array}$ \\
\hline $\begin{array}{l}\text { Alkaline } \\
\text { phosphatase }\end{array}$ & + & + & + & + & + \\
$\begin{array}{l}\text { OCT4 } \\
\text { Embryoid } \\
\text { body }\end{array}$ & + & + & + & + & + \\
$\begin{array}{c}\text { Teratoma } \\
\text { in vivo }\end{array}$ & Yes & Yes & No & Yes & No \\
Chimera & Yes & No & No & Yes & No \\
\hline
\end{tabular}

ESC, embryonic stem cells.

aAccording to Ginis et al. (2004).

'Schneider et al. (2010).

'Yu et al. (2008).

${ }^{\top}$ Brevini et al. (2010).

${ }^{\mathrm{E}}$ Guest and Allen (2007). 
manuscript we will only cover the main characteristics of MSCs and refer the reader to other more comprehensive reviews. The complexity of the field and the lack of standardization and controlled studies in the veterinary field have been recently discussed by Cyranoski (2013) who described the widespread use of MSCs and the lack of properly controlled studies to evaluate how effective these technologies truly are.

The isolation and characterization of MSCs of several domestic animals has been successfully demonstrated. Yet, the wide range of protocols and markers used is daunting. As an example, isolation and characterization of MSC from swine has been reported by multiple groups yet few, if any, examined marker expression but defined MSC solely on the basis of adherence (Ringe et al. 2002). Others used one or two markers (THY1 and ITGAM; Bosch et al. 2005). A few used a complex panel of markers that include CD14-, CD45-, CD44 , $\mathrm{CD}^{+} 0^{+}, \mathrm{CD}_{105^{+}}$and $\mathrm{CD} 29^{+}$(Bruckner et al. 2013). Others separated the MSC population into a subpopulation referred to as Multipotent Adult Progenitor cells or MAPCs, on the basis of their lack of expression of CD44, CD45 and MHC class I and class II genes, and expression of OCT3 (Zeng et al. 2006). For ADSC and BM-MSCs, the work of Bruckner et al. (2013) is notable as not only did they use a comprehensive panel of markers (CD14-, CD45-, CD $44^{+}, \mathrm{CD} 90^{+}, \mathrm{CD} 105^{+}$ and $\mathrm{CD} 29^{+}$) but they were also able to differentiate their MSCs into hepatocyte-like cells, a more complex differentiation that the normally used adipogenic, chondrogenic and osteogenic assays used to characterize the pluripotentiality of MSCs. The heterogeneity of the few papers described above reflects the state of the field, with many investigators working in this area, and with a wide range of rigour in defining their starting population.

In the veterinary field, due to interests in clinical applications, multiple groups are promoting standardization of MSC phenotyping. Schauwer et al. (2011) elegantly summarized why this standardization is needed and provided clear pathways to follow in the equine field. Their recommendations include analysis of MSCs for adherence, positive expression of CD73, CD90 and CD105, and lack of expression of CD34, CD45, CD14, CD11b and MHC class II antigens. Similar recommendations are lacking in other veterinary species at this point. In the horse, the veterinary communities have paid increased attention to stromal cells, (ADSCs or BM-MSCs) as an efficacious treatment option for debilitating and career-ending musculoskeletal injuries. For bone marrow (BM-MSCS) Guest et al. (2008) characterized an extensive positive markers list: CD14, CD29, CD44, CD79 $\alpha$, CD90, MHC-I, MHC-II and Radcliffe et al. (2010) added as markers CD1 la/ CD18, CD29 and CD45RB.

The domestic cat provides a number of important advantages for biomedical research. Martin et al. (2002) published a seminal report on the isolation and characterization of MSCs from cat bone marrow. These cells were isolated and characterized using standard methodology developed for other species, showing similar morphology, growth traits and cell-surface antigen profile, when compared with human and rodents. They also showed in vitro differentiation capacity (adipocytes, osteocytes and neuronal phenotypes when exposed to appropriate induction media), yet, the lines were maintained for only a short time (six passages) and this group suggested that growth factor supplementation may enhance the long-term culture of feline MSC. More recently, Webb et al. (2012) compared the growth and marker characteristics of BM-MSC and ADSC from healthy cats and determined that both had similar marker expression being positive for CD44, CD105 and CD90 and negative for CD4 and MHC Class II. In addition, they concluded that ADSC were a more desirable source due to their higher proliferative capacity and ease of collection.

The state of canine MSCs has recently been reviewed (Bakker et al. 2013) and support expression of CD29, CD73, CD105, CD90, CD44 and Thy-1 in the absence of hematopoietic markers such as CD34 and CD45. Other groups, such as Kamishina et al. (2006), however, identify MSC from canine bone marrow as CD90, MHC-I - Neurogenic positive and CD34, CD45, MHCII negative. Csaki et al. (2007) identified BM-MSC as positive for CD105, CD90 and negative for CD45 and CD34. Neupane et al. (2008) characterized for the first time mesenchymal cells from canine adipose tissue, however, they did not use any cellular markers. The first detailed ADSC characterization was carried out by Vieira et al. (2010) who reported they were CD44, CD29, CD90 positive and CD14, CD34, CD45, CD117 negative. In 2012, several groups reported cell marker expression for canine mesenchymal cells in bone marrow, adipose tissue, muscle, periosteum and umbilical cord. These cells were CD44, STRO-1, CD90, CD29, CD73, CD105 positive and CD34, CD45, CD14, CD146, SSEA-3, SSEA-4, TRA-1-60, TRA-1-81 negative (Guercio et al. 2012; Kang et al. 2012; Kisiel et al. 2012; Takemitsu et al. 2012). Finally, Tryfonidou et al. (2014) reported an extensive testing of human antibodies that could be used to define canine MSC populations. In this review, they described CD271 and the inhouse generated antibodies to MSCA-1, CD56, CD349, $\mathrm{CD} 276$ and CD34. The representative reports described above reflect the variety of markers that are used, or not used, by different groups. In summary, not only are useful reagents continuously being generated and reported, but there is an increasing rigour in the canine literature in terms of description of the MSC populations on the basis of a comprehensive set of cellular markers.

\section{Foetal Stem Cells}

Foetal adnexa (amniotic fluid, amniotic membranes and umbilical cord matrix/blood) are an additional source of MSCs that have high plasticity, high proliferation rate and the ability to differentiate towards multiple lineages. Many studies indicate that these stem cells exhibit some features of ESC including expression of embryonic markers, high proliferation capability and low immunogenicity (Cremonesi et al. 2011; Uranio et al. 2014). Foetal stem cells were first reported in humans (reviewed by Pappa and Anagnou 2009) and have been now isolated and characterized in multiple other species. 
Cremonesi et al. (2011) conducted a review on the progress and prospects of stem cells derived from foetal membranes in domestic and companion animals, summarizing protocols and culture media for canine, equine, porcine, feline, ovine and bovine. They also summarized the phenotype, differentiation potential and described in vivo assays, providing great support for future research. We refer readers to this more comprehensive review. Below, we provide a summary table describing the most recent reports on a range of foetal stem cells in equine, canine, feline and porcine species (Table 2).

\section{Unipotential Progenitor Cells in Regenerative Medicine}

In contrast to pluripotent and multipotent stem cells such as ESC and MSC, progenitor cells do not differentiate into multiple tissues types but into one or, at most, two cell types. As such, their application in regenerative medicine is highly organ and tissue specific. Examples of such cells are muscle progenitor/satellite cells (MPCs) and chondrocytes.

Muscle satellite cells have been shown to be a heterogeneous population of committed myogenic progenitors and non-committed stem cells and represent an abundant, accessible and replenishable source of adult muscle cells (Kuang et al. 2008; O'Brien et al. 2002; Yin et al. 2013). One highly successful clinical application of these cells has been in the treatment of urinary incontinence (UI) in dogs. Eberli et al. (2012) successfully treated canine UI by injections of in vitro expanded MPCs. Briefly, a muscle biopsy was collected from the patient, MPCs isolated, expanded in culture and injected into the damaged sphincter muscle of 12 animals. The animals were followed up for 6 months following injection, and it was demonstrated that sphincter pressure was restored to near $80 \%$ of normal values, indicating that autologous MPCs are able to restore sphincter function (Eberli et al. 2012). This study is an excellent example of the clinical application of an easily collected and expanded cell source for the treatment of a specific condition.

Another important resource in regenerative medicine is the use of chondrocytes in an approach known as autologous chondrocyte implantation (ACI). The idea being to sample healthy cartilage from a patient, expand it in culture and return the cells into the damaged area

Table 2. Description of the most recent papers and kinds of foetal stem cells in equine, canine, feline and porcine

\begin{tabular}{|c|c|c|}
\hline Reference & Species & Source \\
\hline $\begin{array}{l}\text { Red et al. (2007), Kang et al. } \\
\text { (2013) and Barberini et al. (2014) }\end{array}$ & Equine & $\begin{array}{l}\text { Umbilical cord blood, } \\
\text { Umbilical cord matrix, } \\
\text { amnion, amnion fluid }\end{array}$ \\
\hline $\begin{array}{l}\text { Zucconi et al. (2010), Uranio } \\
\text { et al. (2011, 2014) }\end{array}$ & Canine & $\begin{array}{l}\text { Umbilical cord blood, } \\
\text { Amnion and Amnion fluid }\end{array}$ \\
\hline Iacono et al. (2012) & Feline & $\begin{array}{l}\text { Amnion } \\
\text { Aminiotic fluid }\end{array}$ \\
\hline $\begin{array}{l}\text { Carlin et al. (2006) and Chen } \\
\text { et al. (2011) }\end{array}$ & Porcine & $\begin{array}{l}\text { Umbilical cord, Amniotic } \\
\text { Fluid }\end{array}$ \\
\hline
\end{tabular}

of the patient. Unfortunately, in vitro culture of chondrocytes induces their de-differentiation and a gradua conversion into fibroblast-like cells. This transition is accompanied by changes in gene expression and a gradual shift from Collagen $2(C O L 2)$ to Collagen I $(C O L 1)$ expression, and Aggrecan $(A C A N)$ to Versican $(V C A N)$ expression (Schnabel et al. 2002). In an unpublished work, we have recently shown that in vitro expanded porcine chondrocytes can still respond to inductive signals and generate high quality cartilage upon differentiation. Thus, even though their morphology and gene expression profile indicates that they are different from freshly isolated chondrocytes, they can still generate high quality cartilage. When combined with 3D scaffolds, cultured chondrocytes are capable of differentiation into both cartilage and bone, making them an ideal source for orthopedic applications (see review by $\mathrm{Chu}$ et al. 2010 and Chen et al. 2014). Thus, while more restricted in their differentiation potential, adult cells can still play a role in regenerative medicine.

\section{Induced Pluripotent Stem Cells: A Step \\ Forward}

Induced pluripotent stem cells (iPSCs) are generated by induced expression of transcription factors related to pluripotency. This allows a somatic cell in a differentiated state to reverse to an embryonic-like state. Takahashi and Yamanaka (2006) first described this technique in mice whereby incorporation of the transcription factors $O c t 3 / 4$, Sox2, Klf4 and C-myc (OSKM) were sufficient to convert a somatic cell into an ESC-like cell. These cells were referred to as induced pluripotent or iPSC cells. The discovery of such technology was based on the hypothesis that nuclear reprogramming is a process driven by factors that play a critical role in maintaining the pluripotency of ESC (Takahashi and Yamanaka 2006; Yamanaka 2008). The introduction of exogenous pluripotency genes (commonly done by viral vectors such as retrovirus or lentivirus) induce the expression of genes from a pluripotency network (Hotta and Ellis 2008; Jaenich and Young 2008).

The field of induced pluripotency has been growing exponentially and with it the quest for increased efficiency and reproducibility. Many studies have confirmed the repeatability of this process in several species, including rhesus monkey (Liu et al. 2008), cattle (Sumer et al. 2011), rabbits (Honda et al. 2010), sheep (Bao et al. 2011) and others. We recently reviewed (Koh and Piedrahita 2014) the state of the iPSC field in domestic and companion animals, so here we will just briefly summarize the field and provide some examples.

Esteban et al. (2009) reported for the first time iPSC cells from pigs, using Yamanaka factors (OSKMhuman and mouse) in a retrovirus system. More recently, Gao et al. (2014) and Gu et al. (2014) have reported increases in efficiency of generation and stability of pigs iPSC (Gu et al. 2014). In horses, Nagy et al. (2011) established the first horse iPSC using fibroblasts and transcription factors delivery by Piggy$B a c$ transposon. One year later, two groups (Hackett et al. 2012 and Khodadadi et al. 2012) were able to derive equine iPSC without the use of the oncogene 
C-myc. In dogs, Shimada et al. (2010) reported the first canine iPSC generated using OKSM and retroviral vectors. Whitworth et al. (2012) reprogrammed adult fibroblast to iPSC using lentivirus system with OKSM plus Lin 28 and Nanog. The iPSC lines were LIF and $2 \mathrm{i}$ (inhibitors) dependent. Recently, we produced canine iPS from adult fibroblast with OSKM factors and the retrovirus system (Koh et al. 2013). We compared culture conditions (LIF alone, FGF alone or LIF + FGF) and determined that canine iPSC cells were better adapted to grow in a combination of LIF and FGF. We also carried out a detailed chromosomal characterization using both comparative genome hybridization and fluorescence in situ hybridization (FISH) and determined that, as previously reported in humans (Mayshar et al. 2010; Hussein et al. 2011), canine iPSC cells are unstable in culture. Thus, while it is now possible to isolate iPSC cells from a wide variety of species, and using a variety of protocols, their clinical utility remains uncertain until issues of chromosomal instability are resolved.

\section{Conclusion}

Regenerative medicine is rapidly moving forward towards clinical practice, but with stringent FDA regulations for human stem cell applications there is a push for the development of more appropriate animal models. Animals such as dogs (Starkey et al. 2005) horses (Paris and Stout 2010) and pigs (Malaver-Ortega et al. 2012), provide a step forward towards human applications not only because they have many anatomical, physiological and genetic similarities to humans but because they also allow complex and controlled experimentation (Casal and Haskins 2006; review Schneider et al. 2010). In the case of swine, there is the added advantage that recent progress on the use of meganucleases such as Tal effector nuclease (TALENs) and CRISP-CAS9 allows the generation of complex transgenic swine in a highly effective manner (Carlson et al. 2012; Tan et al. 2013; Hai et al. 2014). As a result, not only are there benefits of size and physiology, but also the possibility of developing swine that have pathologies similar to those seen in human patients. This will allow the development of safe and effective cell-based treatments in a large animal model before introduction into the human hospital.

In addition, companion animals such as dogs, cats and horses offer advantages as they carry naturally occurring diseases and lesions much like those seen in a highly heterogonous human population. This will allow the development of technologies that can survive the complexities of treating a highly heterogeneous patient population. Moreover, the development of these technologies will positively impact the lives of the veterinary patient, in addition to helping develop human applications. In short, the combination of advances in stem cell biology, the availability of novel biomaterials, new efficient methods for generating transgenic swine and our increasing understanding of the value of large animal models, promises to drastically accelerate the development of clinical applications in regenerative medicine.

\section{Conflict of interest}

None of the authors have any conflict of interest to declare.

\section{Author contributions}

The authors contributed equally to the manuscript. All contributed to the writing.

\section{References}

Bakker E, Van Ryssen BV, Schauwer C, Meyer E, 2013: Canine mesenchymal stem cells: state of the art, perspectives as therapy for dogs and as a model for man. Vet Q 33, 225-233.

Bao L, He L, Chen J, Wu Z, Liao J, Rao L, Ren J, Li H, Zhu H, Qian L, Gu Y, Dai H, Xu X, Zhou J, Wang W, Cui C, Xiao L, 2011: Reprogramming of ovine adult fibroblasts to pluripotency via druginducible expression of defined factors. Cell Res 21, 600-608.

Barberini DJ, Freitas NP, Magnoni MS, Maia L, Listoni AJ, Heckler MC, Sudano MJ, Golim MA, Landim-Alvarenga FD, Amorim RM, 2014: Equine mesenchymal stem cells from bone marrow, adipose tissue and umbilical cord: immunophenotypic characterization and differentiation potential. Stem Cell Res Ther $\mathbf{1}$, 25.

Blomberg LA, Telugu BP, 2012: Twenty years of embryonic stem cell research in farm animals. Reprod Domest Anim 47, 80-85.

Bosch P, Pratt SL, Stice SL, 2005: Isolation, characterization, gene modification, and nuclear reprogramming of porcine mesenchymal stem cells. Biol Reprod 74 46-57.

Brevini TA, Antonini S, Cillo F, Crestan M, Gandolfi F, 2007: Porcine embryonic stem cells: facts, challenges and hopes. Theriogenology 68, 206-213.

Brevini TA, Pennarossa G, Attanasio L, Vanelli A, Gasparnini B, Gandolfi F, 2010: Culture conditions and signalling networks promoting the establishment of cell lines from parthenogenetic and biparental pig embryos. Stem Cell Res 6, 484 495.

Bruckner S, Tautenhahn HM, Winkler S, Stock P, Dollinger M, Christ B, 2013: A fat option for the pig: hepatocytic differentiated mesenchymal stem cells for translational research. Exp Cell Res 321 , 267-275.

Carlin R, Davis D, Weiss M, Schultz B, Troyer D, 2006: Expression of early transcription factors Oct-4, Sox-2 and Nanog by porcine umbilical cord (PUC) matrix cells. Reprod Biol Endocrinol 6, 4

Carlson DF, Tan W, Lillico SG, Stverakova D, Proudfoot C, Christian M, Voytas DF, Long CR, Whitelaw CB, Fahrenkrug SC, 2012: Efficient TALEN-mediated gene knockout in livestock. Proc Natl Acad Sci USA 109, 17382-17387.
Casal M, Haskins M, 2006: Large animal models and gene therapy. Eur $\mathbf{J}$ Hum Genet 14, 266-272.

Chen JL, Duan L, Zhu W, Xiong J, Wang D, 2014: Extracellular matrix production in vitro in cartilage tissue engineering. $J$ Transl Med 12, 88 .

Chen J, Wei Y, Peng S, Wang H, 2011: Differentiation of porcine amniotic fluid stem cells into the beating cardiomyocytes. Sheng Wu Gong Cheng Xue Bao 27, 1206-1214.

Chu CR, Szczodry M, Bruno S, 2010: Animal models for cartilage regeneration and repair. Tissue Eng Part B 16, 105115.

Cibelli J, Emborg ME, Prockop DJ, Roberts M, Schatten G, Rao M, Harding J, Mirochnitchenko O, 2013: Forum strategies for improving animal models for regenerative medicine. Cell Stem Cell 12, 271-274.

Cremonesi F, Corradetti B, Lange Consiglio A, 2011: Fetal adnexa derived stem cells from domestic animal: progress and perspectives. Theriogenology $\mathbf{7 5}$, 1400-1415.

Csaki C, Matis U, Mobasheri A, Ye H, Shakibaei M, 2007: Chondrogenesis, osteogenesis and adipogenesis of canine 
mesenchymal stem cells: a biochemical, morphological and ultrastructural study. Histochem Cell Biol 128, 507-520.

Cyranoski D, 2013: Stem cells boom in vet clinics. Nature 496, 148-149.

Doetschman T, Gregg RG, Maeda N, Hooper ML, Melton DW, Thompson S, Smithies O, 1987: Targeted correction of a mutant HPRT gene in mouse embryonic stem cells. Nature 330, 576-578.

Eberli D, A boushwareb T, Soker S, Yoo JJ, Atala A, 2012: Muscle precursor cells for the restoration of irreversibly damaged sphincter function. Cell Transplant 21, 2089-2098.

El Omar R, Beroud J, Stoltz JF, Menu P, Velot E, Decot V, 2014: Umbilical cord mesenchymal stem cells: the new gold standard for mesenchymal stem cell-based therapies? Tissue Eng Part B. doi:10.1089/ ten.teb.2013.0664. [Epub ahead of print].

Esteban MA, Xu J, Yang J, Peng M, Qin D, Li W, Jiang Z, Chen J, Deng K, Zhong M, Cai J, Lai L, Pei D, 2009: Generation of induced pluripotent stem cell lines from Tibetan miniature pig. J Biol Chem 284 , 26.

Evans MJ, Kaufman MH, 1981: Establishment in culture of plunipotential cells from mouse embryos. Nature 292, 154 156

Evans MJ, Notarianni E, Laurie S, Moor RM, 1990: Derivation and preliminary characterization of pluripotent cell lines from porcine and bovine blastocysts. Theriogenology 33, 4 .

Feng-Juan LV, Tuan RS, Cheung KMC, Leung VYL, 2014: The surface markers and identity of human mesenchymal stem cells. Stem Cells 32, 1-18.

Galdolfi F, Pennarossa G, Maffei S, Brevini T, 2012: Why is it so difficult to derive pluripotent stem cells in domestic ungulates? Reprod Domest Anim 47, 11-17.

Gao Y, Guo Y, Duan A, Cheng D, Zhang S, Wang H, 2014: Optimization of culture conditions for maintaining porcine induced pluripotent stem cells. DNA Cell Biol 33, 1-11.

Ginis I, Luo Y, Miura T, Thies S, Brandenberger R, Gerecht-Nir S, Amit M, Hoke A, Carpenter JI, Rao MS, 2004: Differences between human and mouse embry onic stem cells. Dev Biol 269, 360-380.

Gómez MC, Serrano MA, Pope CE, Jenkins JA, Biancardi MN, López M, Dumas C, Galiguis J, Dresser BL, 2010: Derivation of cat embryonic stem-like cells from in vitro-produced blastocysts on homologous and heterologous feeder cells. Theriogenology 74, 498-515.

Gu Q, Hao J, Hai T, Wang J, Jia Y, Kong Q, Wang J, Feng C, Xue B, Xie B, Liu S, Li J, He Y, Sun J, Liu L, Wang L, Liu Z, Zhou Q, 2014: Efficient generation of mouse ESCs-like pig induced pluripotent stem cells. Protein Cell 5, 338-342.

Guercio A, Di Marco P, Casella S, Cannella V, Russotto L, Purpan G, Di Bella S, Piccione G, 2012: Production of canine mesenchymal stem cells from adipose tissue and their application in dogs with chronic osteoarthritis of the humeroradial joints. Cell Biol Int 36, 189-194.

Guest DJ, Allen WR, 2007: Expression of cell-surface antigens and embryonic stem cell pluripotency genes in equine blastocysts. Stem Cells Dev 16, 789-796.

Guest DJ, Ousey JC, Smith MRW, 2008 : Defining the expression of marker genes in equine mesenchymal stromal cells. Stem Cells Cloning 1, 1-9.

Guest DJ, Smith MR, Allen WR, 2010: Equine embryonic stem-like cells and mesenchymal stromal cells have differen survival rates and migration pattern following their injection into damaged superficial digital flexor tendon. Equine Vet J 42, 636-642.

Hackett CH, Greve L, Novakofski KD, Fortier LA, 2012: Comparison of gene-specific DNA methylation pattern in equine induced pluripotent stem cell lines with cells derived from equine adult and fetal tissues. Stem Cells Dev 21, 1803 1811.

Hai T, Teng F, Guo R, Li W, Zhou Q, 2014 One-step generation of knockout pigs by zygote injection of CRISPR/Cas system. Cell Res 24, 372-375.

Hatoya S, Torii R, Kondo Y, Okuno T, Kobayashi K, Wijewardana V, 2006: Isolation and characterization ofembryonic stem-like cells from canine blastocysts. Mol Reprod Dev 73, 298-305.

Hayes B, Fagerlie SR, Ramaknishnan A, Bara S, Harkey M, Graf L, 2008: Derivation, characterization, and in vitro differentiation of canine embryonic stem cells. Stem Cells 26, 465-473.

Hipp J, Atala A, 2008: Sources of stem cells for regenerative medicine. Stem Cell Rev 4, 3-11.

Honda A, Hirose M, Hatori M, Matoba S, Miyoshi H, Inoue K, Ogura A, 2010 . Generation of induced pluripotent stem cells in rabbits: potential experimental models for human regenerative medicine. J Biol Chem 285, 31362-31369.

Hotta A, Ellis J, 2008: Retroviral vector silencing during iPS cell induction: an epigenetic beacon that signals distinct pluripotent states. J Cell Biochem 105 , 94-98.

Hussein SM, Batada NN, Vuonisto S, Ching RW, Autio R, Narva E, Ng S, Sourou M, Hamalainen R, Olsson C, Lundin K, Mikkola M, Trokovic M, Peitz M, Brustle O, Bazett-Jones DP, Alitalo K, Lahesmaa R, Nagy A, Otonkoski T, 2011: Copy number variation and selection during reprogramming to plunipotency. Nature 471, 58-64.

Iacono E, Cunto M, Zambelli D, Ricci $\mathrm{F}$, Tazzari PL, Merlo B, 2012: Could fetal fluid and membranes be an alternative source for mesenchymal stem cells (MSCs) in the felinespecies? A preliminary study. Vet Res Commun 2, 107-118.

Jaenich R, Young R, 2008: Stem cells, the molecular circuity of Pluripotency and nuclear reprogramming. Cell 132, 567 582

Kamishina H, Deng J, Oji T, Cheeseman JA, Clemmons RM, 2006: Expression of neural markers on bone marrow-derive canine mesenchymal stem cells. Am J Vet Res 67, 1921-1928.

Kang BJ, Ryu HH, Park SS, Koyama Y, Kikuchi M, Woo HM, Kim WH, Kweon OK, 2012: Comparing the osteogenic potential of canine mesenchymal stem cells derived from adipose tissues, bone marrow, umbilical cord blood, and Whar ton's jelly for treating bone defects. J Vet Sci 13, 299-310.

Kang JG, Park SB, Seo MS, Kim HS, Chae JS, Kang KS, 2013: Characterization and clinical application of mesenchymal stem cells from equine umbilical cord blood. J Vet Sci 14, 367-371.

Khodadadi K, Sumer H, Pashaiasl M, Lim S, Williamson M, Verma PJ, 2012: Induction of plunipotency in adult equine fibroblasts without c-MYC. Stem Cells Int 2012, 429160.

Kisiel AH, McDuffee LA, Masaoud E, Bailey TR, Esparza Gonzalez BP, Nino-Fong R, 2012: Isolation, characterization, and in vitro proliferation of canine mesenchymal stem cells derived from bone marrow, adipose tissue, muscle, and periosteum. Am J Vet Res 73 1305-1317.

Koh S, Piedrahita JA, 2014: From "ES-like" cells to induced pluripotent stem cells: a historical perspective in domestic animals. Theriogenology 81, 103-111.

Koh S, Thomas R, Shendgar T, Bischoff S, Lim J, Breen M, Olby N, Piedrahita JA, 2013: Growth requirements and chromosomal instability of induced plunipotent stem cells generated from adult canine fibroblasts. Stem Cells Dev 22, 951-963.

Kuang S, Gillespie MA, Rudnicki MA, 2008: Niche regulation of muscle satellite cell self-renewal and differentiation. Cell Stem Cell 2, 22-31.

Kuijik EW, Chuva de Sousa Lopes SM, Geijsen N, Macklon N, Roelen BA, 2010 The different shades of mammalian pluripotent stem cells. Hum Reprod Update 17, 254-271.

Lawson KA, Dunn NR, Roelen BA, Zein stra LM, Davis AM, Wright CV, 1999: Bmp4 is required for the generation of primordial germ cells in the mouse embryo. Genes Dev 13, 424-436.

Li X, Zhou SG, Imreh MP, Ährlund-Richter L, Allen WR, 2006: Horse embryonic stem cell lines from the proliferation of inner cell mass cells. Stem Cells Dev 15, $523-531$

Lin CS, Xin ZC, Dai J, Lue TF, 2013 Commonly used mesenchymal stem cell markers and tracking labels: limitations and challenges. Histol Histopathol 28, 1109-1116.

Liu H, Zhu F, Yong J, Zhang P, Hou P, Li H, Jiang W, Cai J, Liu M, Cui K, Qu X, Xiang T, Lu D, Chi X, Gao G, Ji W, Ding M, Deng H, 2008: Generation of induced pluripotent stem cells from adult rhesus monkey fibroblasts. Cell Stem Cell 3, 587590.

Malaver-Ortega LF, Sumera H, Liua J, Verma PJ, 2012: The state of the art for pluripotent stem cells derivation in domestic ungulates. Theriogenology 78 , 1749-1762.

Martin GR, 1981: Isolation of a pluripotent cell line from early mouse embryos cultured in medium conditioned by teratocarcinoma stem cells. Proc Natl Acad Sci USA 78, 7634-7638.

Martin DR, Cox NR, Hathcock TL, Niemeyer GP, Baker HJ, 2002: Isolation and characterization of multipotential 
mesenchymal stem cells from feline bone marrow. Exp Hematol 30, 879-886.

Mayshar Y, Ben-David U, Lavon N, Biancotti JC, Yakir B, Clark AT, Plath K, Lowry WE, Benvenisty N, 2010: Identification and classification of chromosomal aberrations in human induced pluripotent stem cells. Cell Stem Cell 7, 521-531.

Mitalipov S, Wolf D, 2009: Totipotency, pluripotency and nuclear reprogramming. Adv Biochem Eng Biotechnol 114, 185199.

Nagy K, Sung HK, Zhang P, Laflamme S, Vincent P, Agha-Mohammadi S, Woltjen K, Monetti C, Michael IP, Smith LC, Nagy A, 2011: Induced pluripotent stem cell lines derived from equine fibroblasts. Stem Cell Rev 7, 693-702

Neupane M, Chang CC, Kiupel M, Yuz basiyan-Gurkan V, 2008: Isolation and characterization of canine adiposederived mesenchymal stem cells. Tissue Eng 14, 1007-1015.

Nichols J, Smith A, 2011: The origin and identity of embryonic stem cells. Development 138, 3-8.

Nowak-Imialek M, Niemann H, 2012: Pluripotent cells in farm animals: state of the art and future perspectives. Reprod Fertil Dev 25, 103-128

O’Brien K, Muskiewicz K, Gussoni E, 2002 : Recent advances in and therapeutic potential of muscle-derived stem cells. J Cell Biochem Supp 38, 80-87.

Pappa KI, Anagnou NP, 2009: Novel sources of fetal stem cells: where do they fit on the developmental continuum? Regen Med 4, 423-433.

Paris DB, Stout TA, 2010: Equine embryos and embryonic stem cells: defining reliable markers of pluripotency. Theriogenology 74, 516-524.

Patterson DF, 2000: Companion animal medicine in the age of medical genetics. J Vet Intern Med 14, 1-9.

Piedrahita JA, Anderson GB, Bondurant RH, 1990a: Influence of feeder layer type on the efficiency of isolation of porcin embryo-derived cell lines. Theriogenology 34, 865-877.

Piedrahita JA, Anderson GB, BonDurant $\mathrm{RH}, 1990 \mathrm{~b}$ : On the isolation of embry onic stem cells: comparative behavior of murine, porcine and ovine embryos. Theriogenology 34, 879-901

Radcliffe CH, Flaminio MJ, Fortier LA 2010: Temporal analysis of equine bone marrow aspirate during establishment of putative mesenchymal progenitor cel populations. Stem Cells Dev 19, 269-282.

Reed SA, Johson SE, 2007: Equine umbilica cord blood contains a population of stem cells that express Oct 4 and differentiate into mesodermal and endodermal cell types. J Cell Physiol 2, 329-336.

Reubinoff BE, Pera MF, Fong CY, Trounson A, Bongso A, 2000: Embryonic stem cell lines from human blastocysts: somatic differentiation in vitro. Nat Biotechnol 18 399- 404

Ringe J, Kaps C, Schmitt B, Buscher K, Bartel J, Smolian H, Schultz O, Burmester GR, Haupl T, Sittinger M, 2002: Porcine mesenchymal stem cells Induction of dis tinct mesenchymal cell lineages. Cell Tis sue Res 307, 321-327.
Rizzino A, 2013: The Sox2-Oct4 connection: critical players in a much larger interdependent network integrated at multiple levels. Stem Cells 31, 1033-1039.

Saito S, Ugai H, Sawai K, Yamamoto Y, Minamihashi A, Kurosaka K, 2002: Isolation of embryonic stem-like cells from equine blastocysts and their differentiation in vitro. FEBS Lett 531, 389-396.

Schauwer C, Meyer E, Van de Walle GR, Soom AV, 2011: Markers of stemness in equine mesenchymal stem cells: a plea for uniformity. Theriogenology 75, 14311443

Schnabel M, Marlovits S, Eckhoff G, Fichtel I, Gotzen L, Vécsei V, Schlegel J, 2002: Dedifferentiation-associated changes in morphology and gene expression in primary human articular chondrocytes in cell culture. Osteoarthritis Cartilage 10,62-

Schneider MR, Adler H, Braun J, Kienzle B, Wolf E, Kolb HJ, 2007: Canine embryo-derived stem cells - toward clinically relevant animal models for evaluating efficacy and safety of cell therapies. Stem Cells 25, 1850-1851.

Schneider MR, Wolf E, Braun J, Kolb HJ, Adler H, 2010: Embryonic Stem Cells in Domestic Animals Canine embryonic stem cells: state of the art. Theriogenology 74, 492-497.

Shimada H, Nakada A, Hashimoto Y, Shigeno K, Shionoya Y, Nakamura T, 2010: Generation of canine-induced pluripotent stem cells by retroviral transduction and chemical inhibitors. Mol Reprod Dev 77, 2 .

Simara P, Motl JA, Kaufman DS, 2013: Pluripotent stem cells and gene therapy. Transl Res 161, 284-292.

Starkey MP, Scase TJ, Mellersh CS, Murphy S, 2005: Dogs really are man's best friend-canine genomics has applications in veterinary and human medicine!. Brief Funct Genomic Proteomic 4, 112-128.

Strelchenko N, Saito S, Niemann H, 1991: Towards the establishment of bovine embryonic stem cells. Theriogenology 35 , 274.

Strelchenko N, Mitalipova M, Stice S, 1995: Further characterization of bovine plunipotent stem cells. Theriogenology $\mathbf{4 3}, 327$.

Sumer H, Liu J, Malaver Ortega LF, Lim ML, Khodadadi K, Verma PJ, 2011: NANOG is a key factor for induction of pluripotency in bovine adult fibroblasts. J Anim Sci 89, 2708-2716.

Switonski M, Szczerbal I, Nowacka J, 2004 The dog genome map and its use in mammalian comparative genomics. J Appl Genet 45, 195-214.

Takahashi K, Yamanaka S, 2006: Induction of pluripotent stem cells from mouse embryonic and adult fibroblast cultures by defined factors. Cell 126, 663-676.

Takemitsu H, Zhao D, Yamamoto I, Harada Y, Michishita M, Arai T, 2012: Comparison of bone marrow and adipose tissue- derived canine mesenchymal stem cells. BMC Vet Res 8, 150

Tan W, Carlsonc DF, Lancto CA, Garbe JR, Webster DA, Hackett PB, Fahrenkrug SC, 2013: Efficient nonmeiotic allele introgression in livestock using custom endonucleases. PNAS 110, 16526-16531.
Thomas KR, Capecchi MR, 1987: Sitedirected mutagenesis by gene targeting in mouse embryo-derived stem cells. Cell $\mathbf{5 1}$, 503-512.

Thomson JA, Kalishman J, Golos TG, Durning M, Harris CP, Becker RA, Hearn JP, 1995: Isolation of a primate embryonic stem cell line. Proc Natl Acad Sci USA 92, 7844-7848.

Thomson JA, Itskovitz-Eldor J, Shapiro SS, Waknitz MA, Swiergiel JJ, Marshall VS, Jones JM, 1998: Embryonic stem cell lines derived from human blastocysts. Science 282, 1145-1147.

Travis AJ, Kim Y, Meyers-Wallen V, 2009: Development of new stem cell-based technologies for carnivore reproduction research. Reprod Domest Anim 44, 22 28.

Tryfonidou MA, Schumann S, Armeanu S, Harichandan A, Sivasubramaniyan K, Mollenhauer J, Hans-Jorg B, 2014: Update on canine MSC markers. Cytometry A 85A, 379-381.

Uranio FM, Valentini L, Lange-Consiglio A, Caira M, Guanicci AC, L'Abbate A, Catacchio CR, Ventura M, Cremonesi F, Dell'Aquila ME, 2011: Isolation, proliferation, cytogenetic, and molecular characterization and in vitro differentiation potency of canine stem cells from foetal adnexa: a comparative study of amniotic fluid, amnion, andumbilical cord matrix. Mol Reprod Dev 5, 361-373.

Uranio FM, Dell'aquila M, Caira M, Guaricci A, Ventura M, Catacchio C, Martino N, Valentini L, 2014: Characterization and in-vitro differentiation potency of early-passage canine amnion- and umbilicalcord-derived mesenchymal stem cells as related to gestational age. Mol Reprod Dev 81, 539-551.

Vaags AK, Rosic-Kablar S, Gartley CJ, Zheng YZ, Chesney A, Villagomez DA, 2009: Derivation and characterization of canine embryonic stem cell lines with in vitro and in vivo differentiation potential. Stem Cells 27, 329-340.

Vieira NM, Brandalise V, Zucconi E, Secco M, Strauss BE, Zatz M, 2010: Isolation, characterization, and differentiation potential of canine adipose-denived stem cells. Cell Transplant 19, 279-289.

Webb TL, Quimby JM, Dow SW, 2012: In vitro comparison of feline bone marrow-denived and adipose tissuederived mesenchymal stem cells. J Feline Med Surg 14, 165-168.

Whitworth DJ, Ovchinnikov DA, Wolvetang EJ, 2012: Generation and character ization of LIF-dependent canine induced pluripotent stem cells from adult dermal fibroblasts. Stem Cell Dev 21, 2288-2297.

Wilcox JT, Semple E, Gartley C, Brisson BA, Perrault SD, Villagomez DA, 2009 Characterization of canine embryonic stem cell lines derived from different niche microenvironments. Stem Cells Dev 18, $1167-1178$

Yamanaka S, 2008: Pluripotency and nuclear reprogramming. Philos Trans $\mathrm{R}$ Soc Lond B Biol Sci 363, 2079-2087.

Yin H, Price F, Rudnicki MA, 2013: Satellite cells and the muscle stem cell niche. Physiol Rev 93, 23-67. 
Yu X, Jin G, Yin X, Cho S, Jeon J, Lee S, Kong I, 2008: Isolation and characterization of embryonic stem-like cells derived from in vivo-produced cat blastocysts. Mol Reprod Dev 75, 1426-1432.

Zeng L, Rahrmann E, Hu Q, Lund T, Sandquist L, Felten M, O'Brien TD, Zhang J, Verfaillie C, 2006: Multipotent adult progenitor cells from swine bone marrow. Stem Cells 24, 2355-2366.

Zheng Y, Zhang Y, Qu R, He Y, Tian X, Zeng W, 2014: Spermatogonial stem cells from domestic animals progress and prospects. Anim Sci J 147, 65-74.

Zucconi E, Vieira NM, Bueno DF, Secco M, Jazedje T, Ambrosio CE, Passos-Bueno MR, Miglino MA, Zatz M, 2010: Mesenchymal stem cells derived from canine umbilical cord vein-a novel source for cell therapy studies. Stem Cells Dev 3, 395402
Submitted: 4 May 2014; Accepted: 14 Jul 2014

Author's address (for correspondence): JA Piedrahita, 1060 William Moore Dr 27607, Raleigh, NC, USA. E-mail: jorge_piedrahita@ ncsuedu 
Abstracts / Placenta 34 (2013) A1-A99

\section{P2.14.}

\section{CANINE IPSC GENERATION WITH NON-INTEGRATIVE VECTORS}

Natalia J. Gonçalves ${ }^{1}$, Sehwon Koh ${ }^{2}$, Fabiana F. Bressan ${ }^{1}$, Daniele S. Martins ${ }^{1}$, Flávio V. Meirelles ${ }^{1}$, Jorge Piedrahyta ${ }^{2}$, Carlos E. Ambrósio ${ }^{1}$

${ }^{1}$ Department of Veterinary Medicine, Faculty of Animal Science and Food Engineering, Pirassununga, SP, Brazil; ${ }^{2}$ Department of Molecular Biomedical Sciences, College of Veterinary Medicine, North Carolina State University, Raleigh, North Carolina, USA

Episomal vector systems have the potential to avoid undesired side effects, since they behave as separate extrachromosomal elements in the nucleus of a target cell. The main goal of gene therapy is to treat loss-offunction genetic disorders by delivering correcting therapeutic DNA sequences into the nucleus of a cell, allowing its long-term expression at physiologically relevant levels. Production of non-transgenic iPS cells is highly desirable especially in large animal models such as the canine model. Adult canine skin fibroblasts (cSFs) were seeded at 8E5 cells per $10-\mathrm{cm}$ dish and maintained in DMEM/F12 and supplements. Episomal vectors containing the murine pluripotency transcription factors (Oct3/4, Sox2, Klf4 and c-Myc, OKSM) and episome plus each of the OKSM were used to generate independent ciPSC cell lines. Nucleofection of episomal plasmids was performed with Amaxa nucleofection protocol. Cells were transfected twice for eight hours, the vectors were removed and culture media was replaced. On day 6 post-infection, the transfected cells were replated into new MEFs, the next day, culture media was replaced by mTESR. Cell cultures were analysed after non-integrated vectors in each treatment and compared with cells transfected with episomal vector only. It was observed morphological changes in the c-myc transfected culture, resembling iPS colonies. These colonies presented alkaline phosphatase (AP) activity and we confirmed pluripotency marker expression using polymerase chain reaction (PCR). Our findings show the way for the generation of iPSC free of vector integration, excluding problems caused by viral integration, and increasing the therapeutic potential of these cells. The efficiency of canine iPSC in this study, however, was increased when c-myc alone was used in combination with OKSM vector.

http://dx.doi.org/10.1016/j.placenta.2013.06.182 


\title{
Reproduction in Domestic Animals
}

Reprod Dom Anim 47 (Suppl. 6), 8487 (2012); doi: 10.1111/rda.12002

ISSN 0936-6768

\section{Canine Fibroblasts Expressing Human Transcription Factors: What is in the Route for the Production of Canine Induced Pluripotent Stem Cells}

\author{
NJN Gonçalves ${ }^{1}$, FF Bressan ${ }^{2}$, A Souza ${ }^{1}$, DS Martins ${ }^{3}$, MA Miglino ${ }^{1}$, FV Meirelles ${ }^{2}$, F Perecin ${ }^{2}$ and CE Ambrósio ${ }^{2}$ \\ ${ }^{1}$ Department of Surgery, Sector Anatomy, Faculty of Veterinary Medicine and Animal Science, FMVZ/USP, Sao Paulo, Brazil; ${ }^{2}$ Department of \\ Basic Sciences, Faculty of Animal Science and Food Engineering, FZEA/USP, São Paulo, Brazil; ${ }^{3}$ Departament of Animal Science, Faculty of \\ Animal Science and Food Engineering, FZEA/USP, São Paulo, Brazil
}

\section{Contents}

The aim of this study was to further clarify the mechanisms involved in inducing pluripotency using canine foetal fibroblast cells. The two pluripotency-related transcription factors, OCT 4 and SOX2, coupled to a fluorescent reporter gene were transduced, individually or in combination, using a lentivira system. Stable transgenic cell lineages were obtained and canine cells showed to be highly responsive to the integration and expression of human SOX2 and OCT4, also depending on the amount of virus used for incubation. Such positive results are essential for the establishment of pluripotency induction through the incorporation of known transcription factors into the genome of somatic cells

\section{Introduction}

The use of human embryonic stem cells (ESCs) in clinical trials remains controversial because of ethical concerns over the harvesting of human embryos for the isolation of ESCs, and also because of the risks associated with immune rejection of heterologous transplanted ESCs. Consequently, the use of induced pluripotent stem cells (iPSCs) using a set of transcription factors, such as OCT3/4, SOX2, KLF4 and c-MYC (Yamanaka factors), into differentiated somatic cells may help to overcome the immune rejection problem (Takahashi and Yamanaka 2006).

Induced pluripotent stem cells are similar to ESCs in morphology, proliferation and pluripotency. Successful generation of iPSCs has been reported for humans (Takahashi and Yamanaka 2006) and other species (Takahashi et al. 2007; Telugo et al. 2010 including the dog (Luo et al. 2011; Whitworth et al. 2012). Although the use of iPSCs in basic research is moving forward, their use as a therapeutic tool remains a challenge, mostly because of the lack of appropriate animal models for testing their efficacy and safety (Luo et al. 2011).

For a long time, the dog has served as a valuable model for human diseases; thus, approximately $58 \%$ of dog genetic diseases resemble specific human disorders caused by mutations in the same gene (Luo et al. 2011) and - more practically - the lifespan of dogs is considerably longer than that of rodents, thus allowing more adequate long-term studies in disease processes and therapeutics conducted in the rodent models (Whitworth et al. 2012).

Direct reprogramming generates iPSCs with the molecular profile and developmental potential of ESCs. However, several studies have suggested that small differences in gene expression or chromatin modifications yield iPS cell lines with reduced pluripotency when compared with ESCs (Carey et al. 2011). To harness the full potential of iPSC technology, it is important to understand the mechanisms involved. Therefore, the aim of this study was to obtain further information on the cellular mechanisms underlying induced pluripotency in dog cells for the future establishment of iPS cells that can be used for cell therapy and other purposes.

\section{Materials and Methods}

The study protocol was approved by the research ethics committee (2377/2011) of the Faculty of Animal Science and Food Engineering, University of Sao Paulo, Brazil.

\section{Preparation of canine foetal fibroblasts}

Foetal fibroblasts were obtained from one foetus at approximately 30 days of gestation.

Following ovariohysterectomy, the uterus from a pregnant animal was removed and immediately taken to the laboratory as previously described (Miglino et al. 2006; Martins et al. 2011). After aseptic removal of organs and of the head, the foetus was washed in PBS-L (without calcium or magnesium) supplemented with antibiotics ( $1 \%$ penicillin-streptomycin; Invitrogen, Carlsbad, CA, USA) and minced. Fragments of approximately $1 \mathrm{~mm}$ were incubated with collagenase IV (40 mg/ml; Sigma, St. Louis, MO, USA) for $3 \mathrm{~h}$ at $38.5^{\circ} \mathrm{C}$. After incubation, cells were washed and in vitro cultured in Dulbecco's modified Eagle medium (DMEM) (Gibco, Carlsbad, CA, USA, Invitrogen) supplemented with $10 \%$ foetal bovine serum and $1 \%$ penicillin-streptomycin (Gibco, Invitrogen). Culture media were changed every 3 or 4 days until the cells were subconfluent. The foetal fibroblasts were maintained in culture or frozen and stored at $-80^{\circ} \mathrm{C}$ for further experiments.

Lentiviral production and transduction of canine fibroblasts

Plasmids contain the transcription factors human (h) OCT4-vexGFP and SOX2-mCitrine, each of which linked to a fluorescent reporter (Papapetrou et al. 2009 ). Lentiviral production consisted of the lipofection of 293FT cells (Invitrogen) with Lipofectamine 2000 reagent (Invitrogen) following manufacturer's suggestions. Supernatant was recovered at 48 and $72 \mathrm{~h}$ after transfection, filtered and concentrated by ultracentrifugation $(28000 \times \boldsymbol{g}$ for $2 \mathrm{~h})$; supernatant was removed 
by pouring the tube and the remaining media culture was pipetted and used in the transductions. Stable transgenic cell lineages were produced by transducing $10^{5}$ canine fibroblasts cells plated the day before with $100 \mu \mathrm{l}$ or $250 \mu \mathrm{l}$ for SOX2, $100 \mu \mathrm{l}$ for OCT 4 and a mix of the two factors $(50 \mu \mathrm{l}$ for SOX2 and $100 \mu \mathrm{l}$ for OCT4) of the concentrated lentivirus produced with each of the transcription factors supplemented with $6 \mu \mathrm{g} / \mathrm{ml}$ polibrene (Sigma).

\section{Induced pluripotent stem cell culture}

Induced pluripotent stem cells were maintained on mitomycin-treated feeder layers (MEFs) with iPSC medium, which consisted of Dulbecco's modified Eagle's medium/F-12 (Gibco) supplemented with $20 \%$ (v/v) knockout serum (Gibco), minimal essential medium (MEM) non-essential amino acid solution (Sigma), glutamine (Invitrogen), $0.055 \mu \mathrm{M} \quad \beta$-mercaptoethanol, $5 \mathrm{ng} / \mathrm{ml}$ human bFGF (Invitrogen) and $1000 \mathrm{U}$ human LIF (Millipore, Billerica, MA, USA).

\section{Flow cytometry}

Percentage of cells expressing the fluorescent reporter was analysed by flow cytometry (FACSAria; BD Biosciences, San Jose, CA, USA), and positive cells were sorted and in vitro cultured or cryopreserved for further studies. To confirm the stability of SOX2mCitrine and OCT4-vexGFP transgenic canine fibroblasts, assays were performed with qPCR and confocal microscopy.

\section{Confocal microscopy}

Live cells were submitted to confocal microscopy equipped with a fluorescence filter spectrum (Leica TSC SP5 AOBS; Leica Microsystems, Wetzlar, Germany) allowing the analysis of OCT4-vexGFP (excitation laser $405 \mathrm{~nm}$, emission $535 \mathrm{~nm}$ ) and Sox-mCitrine (excitation laser $514 \mathrm{~nm}$, emission $529 \mathrm{~nm}$ ). The pictures were analysed by software LAS-AF (Leica Application Suite and Advanced Fluorescence; Leica Microsystems) with modules Live Data, FRAP, FRET $\mathrm{AB}$ and $\mathrm{SE}$.

\section{Polymerase chain reaction}

Total RNA (from purified samples) was isolated by the method of TRIzol Reagent (Invitrogen). Quantification of RNA was on a UV spectrophotometer at $260 \mathrm{~nm}$. The cDNA High Capacity Reverse Transcription kit (Applied Biosystems, Foster City, CA, USA) was used for cDNA synthesis; this kit uses random hexamers for the conversion of total RNA into cDNA.

Gene expression was assessed by quantitative PCR (Step One Real Time PCR Systems; Life Technologies, Carlsbad, CA, USA). The reactions were performed using a commercial assay system $\left(\mathrm{SYBR}^{\circledR}\right.$ Green PCR Master Mix; Life Technologies); target genes were OCT4 and SOX2. Glyceraldehyde 3-phosphate dehydrogenase gene (GAPDH) served as a housekeeping gene. The sequences of the primers used are shown in
Table 1. Reaction conditions consisted of 40 cycles with annealing temperature of $60^{\circ} \mathrm{C}$. Quantification of OCT4 and SOX 2 was by normalizing the signals with GAPDH signals using the $2^{\mathrm{DDC} C_{\mathrm{t}}}$ method (Livak and Schmittgen 2001).

\section{Results}

Flow cytometry

Stable cell lineages expressing the pluripotency-related transcription factors SOX2-mCitrine, OCT4-vexGFP and SOX2-mCitrine + OCT4-vexGFP were produced. The percentage of positive cells was calculated using nontransduced cells as controls. The results obtained and those after incubation with different volumes of the viruscontaining supernatant are shown in Table 2. Regarding SOX2-positive cells, however not significantly different, fibroblasts transduced with a smaller amount of virus $(100 \mu \mathrm{l})$ showed a higher percentage of positive cells compared with those that were transduced with $250 \mu$ of supernatant ( $96.3 \%$ vs $90.2 \%$ of positive cells).

\section{Confocal microscopy}

Confocal analysis enabled the visualization of the fluorescent protein reporters of both constructs (OCT4-vexGFP and SOX2-mCitrine), also in the double transduced cells (OCT4-vexGFP + SOX2-mCitrine). Both fluorescent proteins were equally distributed throughout the cell cytoplasm (Fig. 1).

\section{Gene expression analysis}

First results obtained on day 6 after transduction show the expression of both transcription factors in transduced cells, while controls were negative (Fig. 2).

\section{Discussion}

Herein, we report the production of genetically modified canine foetal fibroblast cell lines, expressing different

Table 1. Sequences of the primers used for qPCR

\begin{tabular}{ll}
\hline Gene & Sequences $\left(5^{\prime}-3^{\prime}\right)$ \\
\hline OCT4_FWD & CAGGCCCGAAAGAGAAAGC \\
OCT4_REV & CGGGCACTGCAGGAACA \\
SOX2_FWD & TGCGAGCGCTGCACAT \\
SOX2_REV & TCATGAGCGTCTTGGTTTCC \\
GAPDH_FWD & AAGGCCATCACCATCTTCCA \\
GAPDH_REV & CCACTACATACTCAGCACCAGCAT \\
\hline
\end{tabular}

Table 2. Flow cytometry analysis of stable SOX2-mCitrine and OCT4-vexGFP transgenic canine fibroblasts

\begin{tabular}{lc}
\hline Plasmids & Positive cells, $\%$ \\
\hline SOX2-mCitrine $(100 \mu \mathrm{l})$ & 96.3 \\
SOX2-mCitrine $(250 \mu \mathrm{l})$ & 90.2 \\
OCT4-vexGFP $(100 \mu \mathrm{l})$ & 91.4 \\
SOX2-mCitrine $(50 \mu \mathrm{l})+$ OCT4-vexGFP $(100 \mu \mathrm{l})$ & $73.2+92.8$ \\
\hline
\end{tabular}



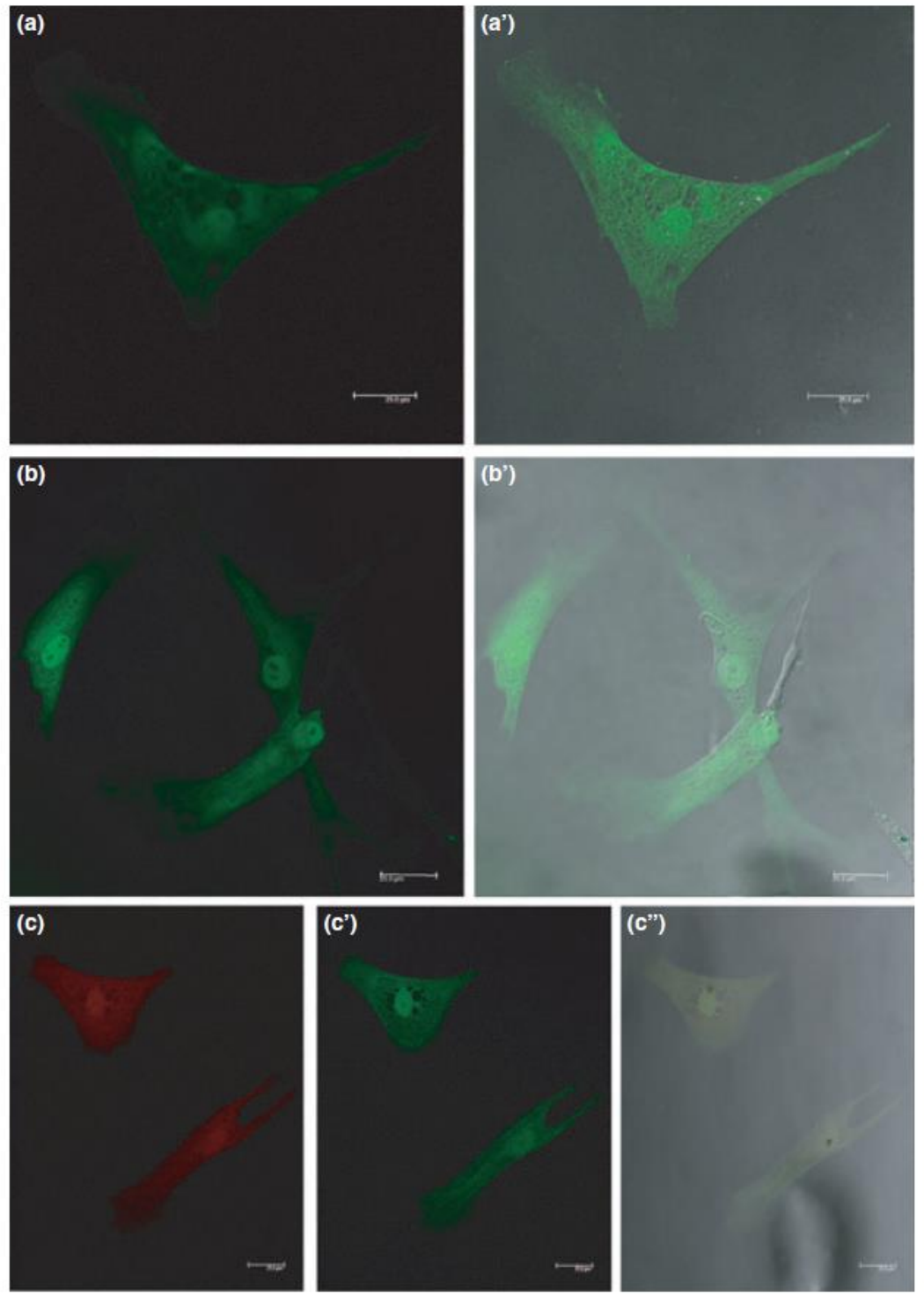

Fig. 1. Micrographs of canine foetal fibroblasts expressing the fluorescent protein reporters. a and a': OCT4-vexGFP and vexGFP merged with bright field, $b$ and $b^{\prime}$ : SOX2-mCitrine and merged; c, $c^{\prime}$ and $c^{\prime \prime}$ : OCT4-vex, SOX2-mCitrine and double positive, respectively

human transcription factors related to pluripotency. Such cell lines are important for the development of IPSC.

The percentage of cells positively transduced was estimated via the fluorescent reporter gene expression and flow cytometry. Canine cells were shown to be highly responsive to the integration and expression of human SOX2 and OCT4 apparently exceeding the responsiveness seen in other species (Huangfu et al. 2008).

Fluorescent microscopy analysis showed that the distribution of reporter proteins was similar for both transcription factors and that protein localization is not restricted to a particular cell region. The characterization of such positive results is essential for the estab- lishment of induction of pluripotency through the incorporation of known transcription factors into the genome of somatic cells.

OCT4 and SOX2 expression in transduced cells showed a high exogenous expression of each targeted gene in single and double transfected cells. However, no interaction between OCT4 and SOX2 was observed, at least until 6 days after transduction. As day 6 after genetic modification is too early to allow for a possible and proper reprogramming of the endogenous genome, gene expression observed in this study must be due to the expression of the 'transgene'. According to Hammachi et al. (2012), OCT4 is an essential regulator of pluripotency in vivo and in vitro in ESCs, as well as a key mediator of the reprogramming of somatic cells into 
Fig. 2. Relative quantification of genes OCT4 (a) and SOX2 (b) using qPCR
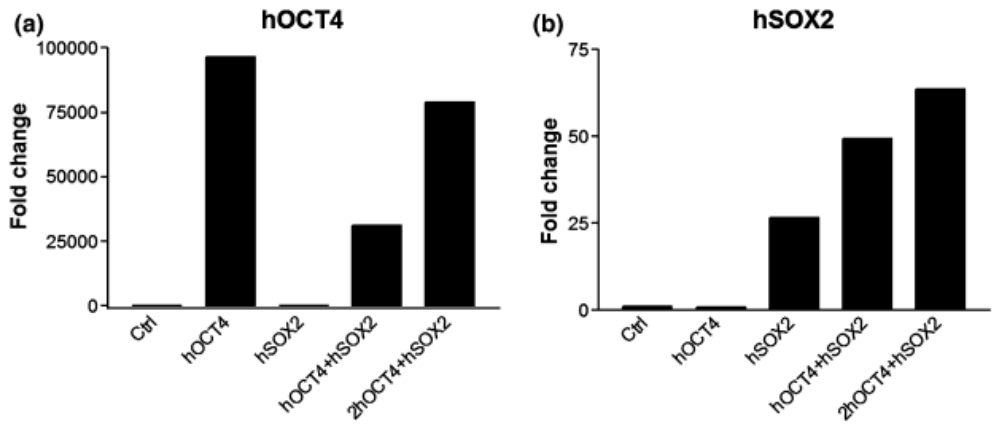

iPSCs, and its interaction with SOX2 may be essential for such purpose (Rizzino 2009).

As already known, species other than humans and mice are refractory to the establishment of true ESCs. Therefore, optimization and characterization of direct reprogramming in domestic animals such as the dog are extremely helpful and may contribute in clarifying the mechanisms involved in cellular reprogramming pathways.

\section{Acknowledgements}

This study was supported by grants from the State of São Paulo Research Foundation (FAPESP grant 2012/01060-4); Gonçalves, NJN and Bressan, FF were supported by FAPESP graduate fellowships 2011/22915-5 and 2009/11631-6, respectively.

\section{Conflicts of interest}

None of the authors have any conflicts of interest to declare.

\section{References}

Carey BW, Markoulaki S, Hanna JH, Faddah DA, Buganim Y, Kim J, Ganz K, Steine EJ, Cassady JP, Creyhhton MP, WElstead GG, Gao Q, Jaenisch R, 2011: Reprogramming factor stoichiometry influences the epigenetic state and biological properties of induced pluripotent stem cells. Cell Stem Cell 9, 588-598.

Hammachi H, Morrison GM, Sharov AA, Livigni A, Narayan S, Papapetrou EP, O'Malley J, Kaji K, Ko MSH, Ptashne M, Brickman JM, 2012: Transcriptional activation by Oct 4 is sufficient for the maintenance and induction of pluripotency. Cell Rep 1, 1-11.

Huangfu D, Osafune K, Maehr R, Guo W, Eijkelenboom A, Chen S, 2008: Induction of pluripotent stem cells from primary human fibroblasts with only OCT4 and SOX2. Nat Biotechnol 26, 1269-1275.

Livak KJ, Schmittgen TD, 2001: Analysis of relative gene expression data using realtime quantitative PCR and the 2(Delta Delta C(T)) method. Methods 25, 402-408 Luo J, Suhr ST, Chang EA, Wang K, Ross

PJ, Nelson LL, Venta PJ, Knott JG, Cibelli JB, 2011: Generation of leukemia inhibitory factor and basic fibroblast growth factor-dependent induced pluripotent stem cells from canine adult somatic cells. Stem cells Dev 20, 1669-1678.

Martins DS, Ambrósio CE, Saraiva NZ, Wenceslau CV, Morini AC, Kerkis I, Garcia JM, Miglino MA, 2011: Early development and putative primordial germ cells characterization in dogs. Reprod Domest Anim 46, 62-66.

Miglino MA, Ambrósio CE, dos Santos Martins D, Wenceslau CV, Pfarrer C, Leiser R, 2006: The camivore pregnancy: the development of the embryo and fetal membranes. Theriogenology 66, 1699 1702 .

Papapetrou EP, Tomishima MJ, Chambers SM, Mica Y, Reed E, Menon J, Tabar V, Mo Q, Studer L, Sadelain M, 2009: Stoichiometric and temporal requirements of Oct4, Sox2, K1f4, and c-Myc expression for efficient human iPSC induction and differentiation. Proc Natl Acad Sci USA 106, 12759-12764.

Rizzino A, 2009: Sox 2 and Oct-3/4: a versatile pair of master regulators that orchestrate the self-renewal and pluripotency of embryonic stem cells by functioning as molecular rheostats. Wiley Interdiscip Rev Syst Biol Med 1, 228236.
Takahashi K, Yamanaka S, 2006: Induction of pluripotent stem cells from mouse embryonic and adult fibroblast cultures by defined factors. Cell 126, 663-676.

Takahashi K, Tanabe K, Ohnuki M, Ichisaka T, Tomoda K, Yamanaka S, 2007: Induction of pluripotent stem cells from adult human fibroblasts by defined factors. Cell 131, 861-872.

Telugo BP, Ezashi T, Roberts RM, 2010: The promise of stem cell research in pigs and other ungulate species. Stem Cell Rev 6, 31-41.

Whitworth DJ, Ovchinnikov DA, Wolvetang EJ, 2012: Generation and characterization of LIF-dependent canine induced pluripotent stem Cells from adult derma fibroblasts. Stem Cells Dev 21, 2288-2297.

Submitted: 30 May 2012; Accepted: 29 Jun 2012

Author's address (for correspondence): $\mathrm{CE}$ Ambrósio, Department of Basic Sciences, Faculty of Animal Science and Food Engineering, FZEA/USP, Pirassununga, São Paulo 13635-900, Brazil.

E-mail: ceambrosio@usp.br 


\section{Agência RTAPESP}

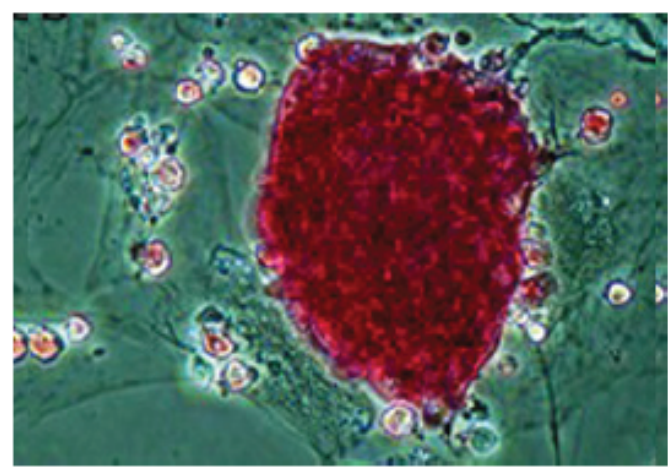

Parceria busca linhagem segura de células-tronco para tratar lesão medular

02 de dezembro de 2013

\section{Por Karina Toledo}

Agência FAPESP - A obtenção de linhagens seguras de células-tronco pluripotentes para

serem usadas, por exemplo, no tratamento de lesões medulares e doenças genéticas como distrofia muscular é o principal objetivo de um projeto que reúne pesquisadores da Universidade de São Paulo (USP) e da North Carolina State University, nos Estados Unidos.

Os primeiros resultados foram apresentados pelo professor Carlos Eduardo Ambrósio, da Faculdade de Zootecnia e Engenharia de Alimentos (FZEA) da USP, em Pirassununga, durante a programação da FAPESP Week North Carolina, no dia 12 de novembro.

"Estamos trabalhando com linhagens de células animais adultas nas quais induzimos a pluripotência [capacidade equivalente à das células-tronco embrionánias de se diferenciar em qualquer tecido]. Nosso foco é obter uma linhagem segura, sem o potencial de formar tumores, para ser usada em testes pré-clínicos e clínicos ${ }^{n}$, contou Ambrósio.

O projeto - coordenado por Ambrósio e por Jorge Piedrahyta, da Faculdade de Medicina Veterinária da North Carolina State University - foi um dos aprovados na mais recente chamada de propostas lançada no âmbito da University Global Partnership Network (UGPN). O consórcio internacional formado pela USP, pela North Carolina State University e pela University of Surrey, no Reino Unido, tem o objetivo de fomentar a colaboração entre acadêmicos das três instituições.

O trabalho também está vinculado a um Auxilio à Pesquisa - Regular da FAPESP coordenado por Ambrósio no Brasil.

Para induzir a pluripotência em fibroblastos de cachorros, os pesquisadores usam a técnica premiada com o Nobel de Medicina em 2012 e descrita em 2006 por Shinya Yamanaka, da Universidade de Kyoto, no Japão. O método consiste em inserir na célula adulta da pele certas proteínas - conhecidas como fatores de transcrição - capazes de reprogramar o genoma celular. 
$24 / 08 / 2015$

Agéncia FAPESP | Parceria busca linhagen segura de células-tronco para tratar lesão medular

Esses fatores de transcrição ativam genes relacionados ao estágio embrionário da célula e desligam outros genes que deveriam estar ativos após o amadurecimento celular.

O trabalho de adaptação da técnica para a obtenção de células-tronco pluripotentes induzidas (IPS, na sigla em inglês) caninas foi descrito em artigo publicado na revista Reproduction in Domestic Animals. Rendeu ainda um artigo divulgado recentemente na revista Placenta.

"A técnica descrita por Yamanaka propõe o uso de quatro diferentes fatores de transcrição: OCT3/4, SOX2, KLF4 e C-MYC. Mas, ao mesmo tempo que isso induz a pluripotência na célula, também a torna altamente teratogênica [capaz de induzir a formação de tumores do tipo teratoma, composto de tecidos mistos]. O que estamos tentando fazer agora, por enquanto em experimentos in vitro, é obter uma IPS com um número reduzido de fatores de transcrição. Acreditamos que isso possa diminuir o potencial carcinogênico da célula. Também pretendemos gerar inúmeras linhagens brasileiras e americanas e realizar estudos da reação do cultivo celular com diferentes fatores de crescimento, bem como realizar a análise das sequências gênicas dessas células", explicou Ambrósio.

Outra estratégia do grupo é modular o genoma celular por meio de ferramentas como a Talen (Transcription activator-like effector nucleases), grupo de enzimas que possibilita ativar ou desativar genes de interesse. Esse trabalho está sendo realizado na Carolina do Norte durante o doutorado de Natalia Juliana Nardelli Gonçalves, com Bolsa da FAPESP e orientação de Ambrósio. A primeira etapa foi realizada por Gonçalves durante estágio no exterior também com Bolsa da FAPESP.

Já durante o mestrado de Helena Debiazi Zomer, com Bolsa da FAPESP e orientação de Ambrósio, foram estudadas a obtenção de IPS de coelhos a partir de células-tronco do tecido adiposo.

\section{Banco de células-tronco}

Entre os anos de 2008 e 2011, por meio de um Auxilio à Pesquisa - Apoio a Jovens Pesquisadores, Ambrósio investigou diversas formas para obter células-tronco mesenquimais - capazes de se diferenciar em alguns tipos de tecido, como ossos, cartilagem e gordura - de diversos animais.

O trabalho resultou na criação de um banco que reúne mais de dez linhagens de célulastronco de cachorro, gato, ovelha e porco. Esse acervo hoje está ligado ao Laboratório de Morfofisiologia Molecular e do Desenvolvimento da FZEA, coordenado pelo professor Flávio Vieira Meirelles, e à nova Unidade Didática Clínico Hospitalar, concebida com a intenção de gerar inovações terapêuticas para fins veterinários.

"Além da terapia celular, também testamos a terapia gênica, usando ferramentas de edições 
de genes em culturas celulares de músculos de cães com distrofia muscular. Tentamos, in vitro, corrigir o gene defeituoso causador da doença", explicou.

Na avaliação de Ambrósio, a geração de conhecimento sobre manipulação de células-tronco e edição de genes pode contribuir para o tratamento de doenças crônicas e genéticas em animais, com aplicações futuras para humanos. 
Abstracts/ Placenta 35 (2014) A1-A112

\section{P2.100. \\ RREPROGRAMMING BY GENE INDUCTION: THE FACTORS INVOLVED IN THE ESTABLISHMENT OF CANINE STEM CELLS}

Natalia Gonçalves, Fabiana Bressan, Flávio Meirelles, Carlos Ambrósio Faculty of Animal Science and Food Engineering, University of Sao Paulo, Pirassumunga, Brazil

Takahashi and Yamanaka established a technique where transcription factors related to pluripotency were incorporated in the genome of somatic cells in order to reprogram these cells. The expression of these transcription factors enables a somatic cell that presents a differentiated condition to reverse it to an embryonic state, generating induced pluripotent stem cells (iPSC). The production of iPSC from canine fetal fibroblasts was performed with lentiviral integrative systems by policistronic humam and mouse vectors (Stemcca), aiming to obtain cultures of pluripotent stem cells that would develop patterns of gene expression and epigenetic similar to cells derived from the animal model. Canine iPSC lines were produced and these clonal lines were cultivated with bFGF and independently of LIF and presented morphological characteristics that are more close to iPSCs produced in other species such as bovine than to previously described canine iPSC. In the first day after transduction, no differences were observed between murine and human infection. The cells in the reprogramming process presented early colonies at 11 days after transduction, who kept stable and similar to the stem cell morphological patterns. These colonies were picked by hand at the first passage and thereafter Tryple was successfuly used. Such cell lines were alkaline phosphatase positive, had the ability to form embryonic bodies, to spontaneously differentiate and to express pluripotency-related genes (Oct4, Sox2). This work demonstrates it was possible to efficiently reprogram canine somatic cells using lentiviral vectors and proves these cell lines are pluripotent through posive results on the pluripotency tests. Also, these new results combining the use of Tryple enzyme and bFGF supplementation only, unlike what has been done for this specie. 